\title{
ipen
}

AUTARQUIA ASSOCIADA À UNIVERSIDADE DE SÃO PAULO

\section{MODIFICAÇÃO DE POLI(FLUORETO DE VINILIDENO) INDUZIDA POR RADIAÇÃO GAMA PARA APLICAÇÃO COMO COMPÓSITO IONOMÉRICO DE METAL-POLÍMERO}

HENRIQUE PEREZ FERREIRA

Dissertação apresentada como parte dos requisitos para obtenção do Grau de Mestre em Ciências na Área de Tecnologia Nuclear - Materiais

Orientador:

Prof. Dr. Ademar Benévolo Lugão 
INSTITUTO DE PESQUISAS ENERGÉTICAS E NUCLEARES - IPEN

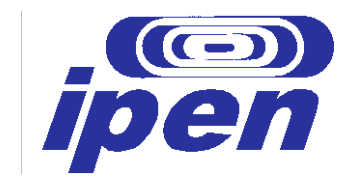

Autarquia Associada à Universidade de São Paulo

\section{MODIFICAÇÃO DE POLI(FLUORETO DE VINILIDENO) INDUZIDA POR RADIAÇÃO GAMA PARA APLICAÇÃO COMO COMPÓSITO IONOMÉRICO DE METAL-POLIIMERO}

HENRIQUE PEREZ FERREIRA

Dissertação apresentada como parte dos requisitos para obtenção do grau de Mestre em Ciências na área de Tecnologia Nuclear - Materiais.

Orientador:

Dr. Ademar Benévolo Lugão

São Paulo

2011 


\begin{abstract}
À minha família, professores e amigos, por terem importante participação nas mudanças que ocorrem a cada dia e que tanto colaboram para meu crescimento...
\end{abstract}




\section{AGRADECIMENTOS}

Agradeço primeiramente aos meus pais, por tudo o que fizeram por mim, ontem, hoje e sempre, apesar de todas as dificuldades.

Ao meu orientador Prof. Dr. Ademar B. Lugão, pela confiança, paciência, ensinamentos, incentivo e orientação.

Ao Dr. Antônio Brant, pela amizade e por toda a colaboração ao longo do desenvolvimento deste trabalho.

À Dra. Susana Torresi, por tão gentilmente participar da comissão examinadora e contribuir para a melhoria do trabalho.

Ao Instituto de Pesquisa Energética e Nucleares (IPEN/CNEN-SP) pela oportunidade de desenvolver este trabalho.

Ao Conselho Nacional de Desenvolvimento Científico e Tecnológico (CNPq), pela bolsa concedida - Processo № 136511/2008-2.

À Empresa Brasileira de Radiações (EMBRARAD/CBE) pela irradiação dos filmes poliméricos.

À Prof. Drạ. Duclerc F. Parra, pela amizade e por toda sua ajuda e colaboração, tanto durante o desenvolvimento deste trabalho quanto fora dele.

Ao Sr. Eleosmar Gasparin do Centro de Química e Meio Ambiente (CQMA) do IPEN/CNEN-SP pelas análises térmicas e pela amizade e ajuda.

Aos Srs. Celso Vieira e Glauson Machado, do Centro de Ciência e Tecnologia dos Materiais do IPEN/CNEN-SP, pelas análises de microscopia eletrônica de varredura (MEV).

Ao Sr. Vinicius Freire Elias, do Laboratório de Microscopia Eletrônica da Escola Politécnica da Universidade de São Paulo, pelas análises de Microscopia Eletrônica de Varredura (MEV) e Espectroscopia de Energia Dispersiva (EDS). 
Aos meus amigos do CQMA: Adriana Napoleão, Andréia Navarro, Camila Pinheiro, Carolina Ikari, Danilo Fermino, Débora Salum, Edgar Ferrari, Edson Takeshi, Edson Gibelli, Elen Pimentel, Elisabeth Cardoso, Geise Ribeiro, Gerhardyne Rosner, Harumi Otaguro, Helber Holland, Hellen Costenaro, Heloisa Zen, Jacinete dos Santos, João Batista, Jorge Vaz, José Brandão, José Pereira, José Seneda, Justine Oliveira, Leonardo Marchini, Liana Nakamura, Luis Filipe Lima, Luiza Melo, Mara Alcântara, Maria Cláudia Felinto, Maria José Oliveira, Mitiko Yamaura, Natalia Naime, Nayara Egute, Nelson Bueno, Oscar Vega, Pedro Forster, Pedro Vicente, Patrícia Ponce, Paula Paganini, Renata Barreto, Ricardinho Cavaleiro, Rodrigo Shinzato, Ruth Camilo, Sandra Scagliusi, Tamiris Federiji, Thiago Gomes, Valdelei Almeida, Washington Oliani; pelo carinho e o apoio recebido desde que cheguei ao IPEN.

A todos os amigos que fiz ao longo desses anos no IPEN, pessoas ótimas de quem sempre lembrarei: Afonso Aquino, Ana Copat, Christina Forbicini, Clarissa Dias, Daniele Gianinni, Dionísio Fortunato, Ilze Puglia, Izilda Cruz, Ligia Lulio, Lucas Pinheiro, Marcelo Bardi, Marco Antonio, Mauro Dresch, Rafael Bonifáfio, Roberta Alvarenga, Rosely Orsini, Shayenne Nóbrega, Sirlane Gomes.

Aos amigos Bianca Sufi, Caroline Ferraz, Clécia Souza, Giovana Gimiliani, Luiza Stecher, Rodrigo Mosca e Stefany Santin pelo incentivo, carinho, amizade e pelas horas de almoço, sempre tão divertidas.

A todos os professores e amigos que contribuíram direta ou indiretamente para minha formação e para o desenvolvimento do trabalho.

Às moças da limpeza e aos rapazes da segurança e manutenção, que sempre mantiveram tudo em ordem. 


\section{SUMÁRIO}

Página

1 INTRODUÇÃO

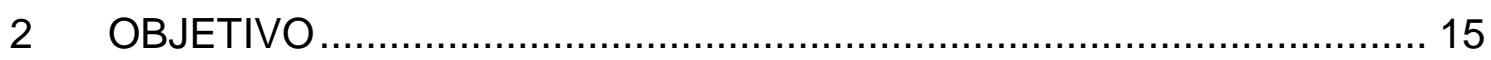

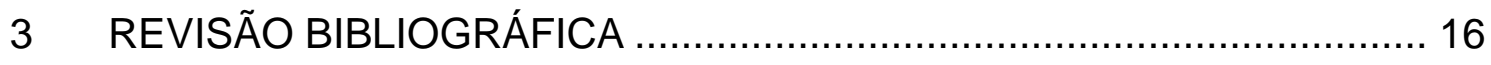

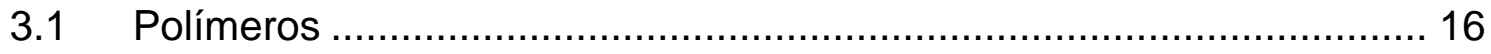

3.1.1 Classificação dos polímeros ......................................................... 16

3.1.2 Homopolímeros e copolímeros.................................................... 19

3.2 Poli(fluoreto de vinilideno) - PVDF ................................................ 20

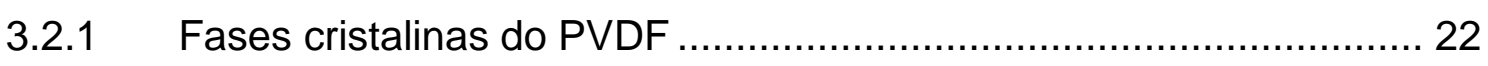

3.3 Efeitos das radiações nos materiais ................................................. 26

3.3.1 Efeitos da radiação nos polímeros …………………………...... 27

3.3.2 Enxertia Induzida por Radiação ……………………………........ 29

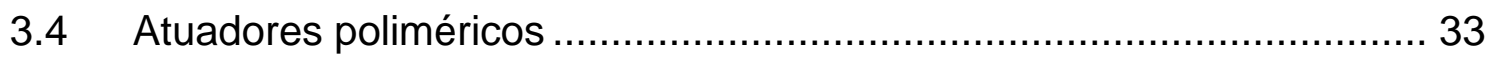

3.4.1 Compósito ionomérico de metal-polímero (IPMC) ............................. 34

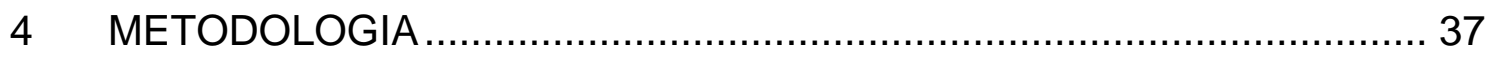

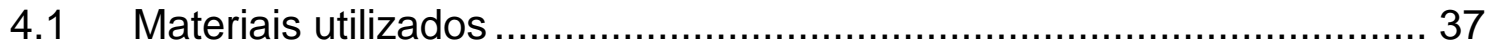

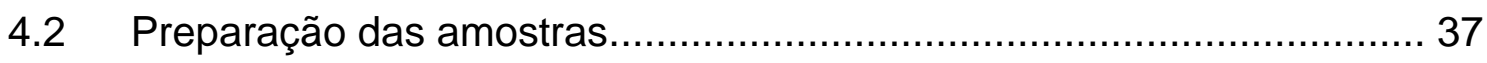

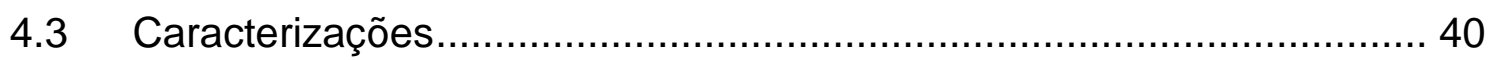

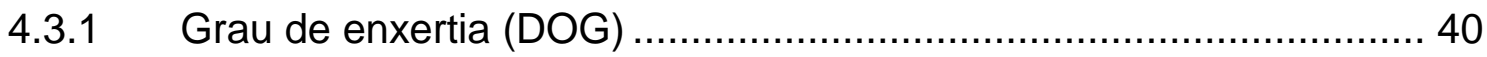

4.3.2 Intumescimento do PVDF nas soluções........................................... 40

4.3.3 Espectrometria vibracional no infravermelho (FT-IR) ...................... 40

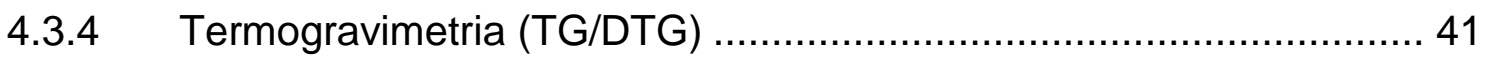

4.3.5 Calorimetria exploratória diferencial (DSC) …................................. 41 
4.3.6 Cálculo da capacidade de troca iônica (IEC) ............................ 41

4.3.7 Microscopia eletrônica de varredura (MEV) ................................ 42

4.3.8 Espectroscopia de energia dispersiva (EDS) ............................ 42

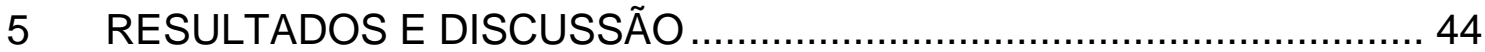

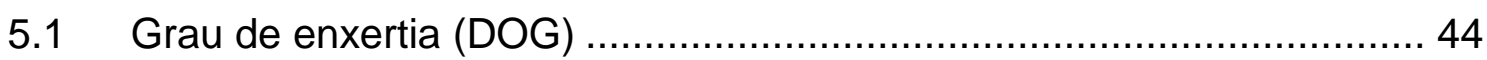

5.2 Microscopia eletrônica de varredura (MEV) ..................................... 47

5.3 Espectroscopia de energia dispersiva (EDS) .............................. 55

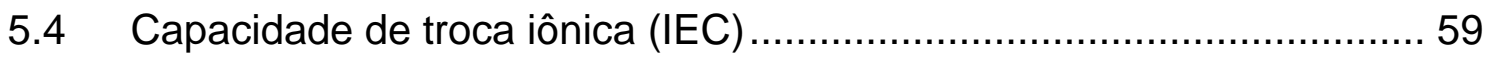

5.5 Calorimetria exploratória diferencial (DSC) …................................ 61

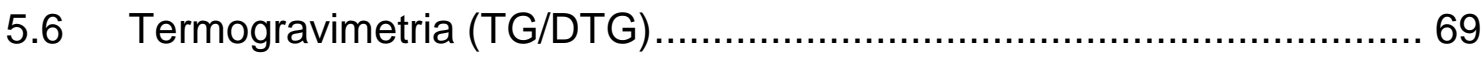

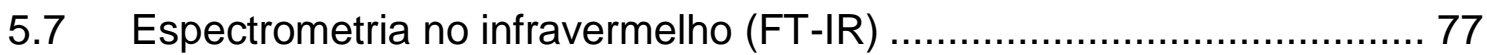

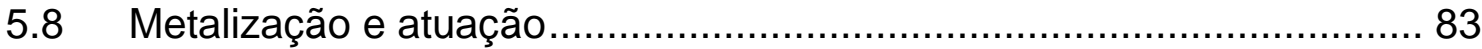

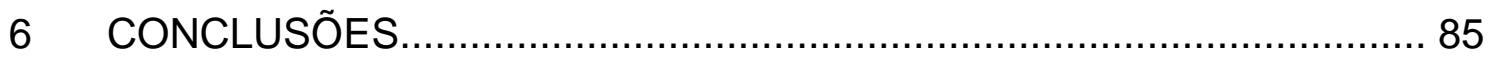

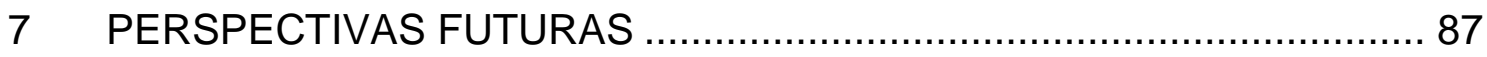

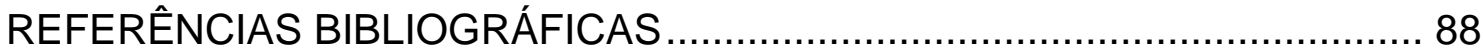




\section{LISTA DE FIGURAS}

\section{Página}

Figura 1 - Estereoisomerias. a) isotático; b) sindiotático; c) atático. .....................18

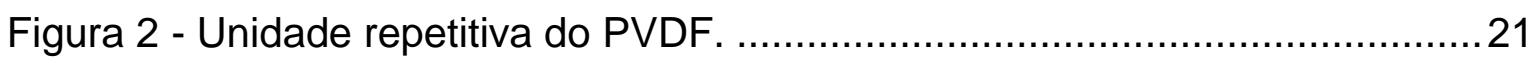

Figura 3 - Etapas para produção do monômero VDF...........................................21

Figura 4 - Representação da estrutura e célula unitária do PVDF na forma alfa.

Figura 5 - Representação da estrutura e célula unitária do PVDF na forma beta.

Figura 6 - Representação da estrutura e célula unitária do PVDF na forma gama.

Figura 7 - Representação da estrutura e célula unitária do PVDF na forma delta. 25

Figura 8 - Espectros de FT-IR do PVDF utilizado neste trabalho, com os picos característicos das fases cristalinas. 25

Figura 9 - Reações primárias e secundárias induzidas pela radiação ionizante.

Figura 10 - Principais radicais formados pela irradiação do PVDF. 28

Figura 11 - Etapas da reação de polimerização induzida por radiação. 30

Figura 12 - Representação de estrutura de PVDF enxertado e sulfonado. 32

Figura 13 - Representação da flexão e da difusão de cátions e de moléculas de água pelo polímero antes e depois da aplicação de potencial elétrico.

Figura 14 - llustração do sistema utilizado para testar a movimentação dos IPMCs.

Figura 15 - Grau de enxertia para diferentes doses e com ambos os solventes. 
Figura 16 - Intumescimento do PVDF em DMF, tolueno e nas soluções destes com estireno.

Figura 17 - Micrografias de superfície de filme de PVDF prístino.

Figura 18 - Micrografias de superfícies de filmes de PVDF enxertado em estireno/DMF em diferentes doses: 1 kGy (A e B); 10 kGy (C e D) e 40 kGy (E e F).

Figura 19 - Micrografias de superfícies de filmes de PVDF enxertado em estireno/tolueno com dose de 5 kGy (A e B), 10 kGy (C e D) e 40 kGy (E e F). 50

Figura 20 - Micrografias de superfície do filme de PVDF enxertado em DMF/estireno com dose de 100 kGy

Figura 21 - Micrografias de superfície do filme de PVDF enxertado em tolueno/estireno com dose de $100 \mathrm{kGy}$.

Figura 22 - Micrografias de superfícies de amostras enxertadas em solução contendo DMF e sulfonadas com solução a $2 \%$ (A,B,E,F) e 10\% (C,D,G,H) de ácido clorossulfônico.

Figura 23 - Micrografias de superfícies das amostras enxertadas em solução contendo tolueno e sulfonadas com solução a $10 \%$ de ácido clorossulfônico. 54

Figura 24 - Micrografias de superfície das amostras enxertadas em DMF com dose de $100 \mathrm{kGy}$ e sulfonadas com solução a $2 \%$ (A) e 10\% (B) de ácido clorossulfônico. 55

Figura 25 - Espectro de EDS do PVDF prístino. 56

Figura 26 - Espectros de EDS do PVDF enxertado em tolueno (a) e em DMF (b) com dose de 40 kGy. 56

Figura 27 - Espectros de EDS do PVDF enxertado em dose de $40 \mathrm{kGy}$ em tolueno (a, b) e em DMF (c, d) e sulfonadas com $2 \%$ (amostras a e c) e $10 \%$ (amostras b e d) de ác. clorossulfônico. 57

Figura 28 - IEC das amostras enxertadas em solução com tolueno. 59 
Figura 29 - IEC das amostras enxertadas em solução com DMF. 60

Figura 30 - Curvas de DSC da cristalização de amostras prístina e enxertadas em DMF.

Figura 31 - Curvas de DSC da cristalização das amostras prístina e enxertadas em tolueno.

Figura 32 - Curvas de DSC do PVDF prístino e enxertadas em DMF e em tolueno em 10 kGy.

Figura 33 - Curva de DSC do poliestireno. 63

Figura 34 - Curvas de DSC das amostras enxertadas em DMF e em tolueno com diferentes doses de irradiação.

Figura 35 - Curvas de DSC das amostras enxertadas em DMF e sulfonadas a $2 \%$ e $10 \%$.

Figura 36 - Curvas de DSC das amostras enxertadas em tolueno e sulfonadas a $2 \%$ e $10 \%$.

Figura 37 - Cristalinidades das amostras enxertadas em tolueno em função da dose de irradiação.

Figura 38 - Cristalinidades das amostras enxertadas em DMF em função da dose de irradiação.

Figura 39 - Cristalinidades das amostras enxertadas em tolueno e sulfonadas, em função da dose de irradiação e concentração de ácido clorossulfônico.

Figura 40 - Cristalinidades das amostras enxertadas em DMF e sulfonadas, em função da dose de irradiação e concentração de ácido clorossulfônico.

Figura 41 - Curvas de TG e DTG do PVDF prístino em atmosfera de nitrogênio e de oxigênio.

Figura 42 - Curvas de TG e DTG do poliestireno em atmosfera de nitrogênio e de oxigênio.

Figura 43 - Curvas de TG do polímero prístino, das amostras enxertadas em DMF e em tolueno em atmosfera de nitrogênio. 
Figura 44 - Curvas de DTG do polímero prístino, das amostras enxertadas em DMF e em tolueno em atmosfera de nitrogênio.

Figura 45 - Curvas de TG dos polímeros enxertados em DMF e sulfonados.

Figura 46 - Curvas de DTG dos polímeros enxertados em DMF e sulfonados.

Figura 47 - Curvas de TG do polímero prístino, das amostras enxertadas em tolueno e sulfonadas. 74

Figura 48 - Curvas de DTG do polímero prístino, das amostras enxertadas em tolueno e sulfonadas. 75

Figura 49 - Curvas de TG em atmosfera de $\mathrm{O}_{2}$ do polímero prístino e enxertado em tolueno.

Figura 50 - Curvas de DTG em atmosfera de $\mathrm{O}_{2}$ do polímero prístino e enxertado em tolueno.

Figura 51 - Curvas de TG em atmosfera de $\mathrm{O}_{2}$ do polímero prístino e enxertado em DMF.

Figura 52 - Curvas de DTG em atmosfera de $\mathrm{O}_{2}$ do polímero prístino e enxertado em DMF.

Figura 53 - Espectros de infravermelho das amostras de PVDF prístino, enxertado em DMF e em tolueno.

Figura 54 - Espectros de FT-IR das amostras de PVDF prístino, enxertado em DMF e, a seguir, sulfonado.

Figura 55 - Espectros de FT-IR de amostras sulfonadas depois de enxertadas em tolueno e em DMF. 82

Figura 56 - Amostras sulfonadas após etapa de metalização. 83 


\title{
MODIFICAÇÃO DE POLI(FLUORETO DE VINILIDENO) \\ INDUZIDA POR RADIAÇÃO GAMA PARA APLICAÇÃO COMO COMPÓSITO IONOMÉRICO DE METAL-POLÍMERO
}

\author{
Henrique Perez Ferreira
}

\section{RESUMO}

Foi estudada a enxertia de estireno induzida por radiação gama em filmes de poli(fluoreto de vinilideno) (PVDF) com espessura de 0,125 mm com doses entre 1 e 100 kGy em presença de soluções de estireno/ $N, N$ dimetilformamida (DMF) $(1: 1, \mathrm{v} / \mathrm{v})$ e estireno/tolueno $(1: 1, \mathrm{v} / \mathrm{v})$ com taxa de dose de $5 \mathrm{kGy} \cdot \mathrm{h}^{-1}$ por meio do método simultâneo de irradiação sob atmosfera de nitrogênio e em temperatura ambiente, usando raios gama de uma fonte de Co60. Depois de enxertados, os polímeros foram sulfonados em soluções de ácido clorossulfônico/1,2-dicloroetano (2 e 10 \%). Os filmes foram caracterizados antes e depois de cada modificação com o cálculo do Grau de enxertia, (DOG), espectrometria no infravermelho (FT-IR), microscopia eletrônica de varredura (MEV), calorimetria exploratória diferencial (DSC) e termogravimetria (TG/DTG). Os resultados do grau de enxertia mostraram que a enxertia aumenta com o aumento da dose e varia enormemente de acordo com o solvente utilizado, com enxertias cerca de 20 vezes maiores quando do uso da DMF em relação ao do tolueno. Foi possível confirmar a enxertia do estireno por FT-IR graças ao aparecimento de novos picos característicos e por TG/DTG e DSC por meio das alterações do comportamento térmico dos materiais enxertados/sulfonados. Os materiais sulfonados ainda foram caracterizados por suas capacidades de troca iônica (IEC), que mostraram que tanto os aumentos do grau de enxertia quanto os da concentração do ácido clorossulfônico aumentam o IEC. Os resultados mostraram que é possível obter materiais com capacidades de troca iônica com possibilidade de aplicação como compósitos ionoméricos de metal-polímero. 


\title{
POLY(VINYLIDENE FLUORIDE) MODIFICATION INDUCED BY GAMMA IRRADIATION FOR APPLICATION AS IONIC POLYMER-METAL COMPOSITE
}

\author{
Henrique Perez Ferreira
}

\begin{abstract}
Gamma-radiation-induced grafting of styrene into poly(vinylidene fluoride) (PVDF) films with $0.125 \mathrm{~mm}$ thickness at doses from 1 to $100 \mathrm{kGy}$ in the presence of a styrene/ $N, N$ - dimethylformamide (DMF) solution $(1: 1, \mathrm{v} / \mathrm{v})$ and styrene/toluene $(1: 1, \mathrm{v} / \mathrm{v})$ at dose rate of $5 \mathrm{kGy} \mathrm{h}^{-1}$ was carried out by simultaneous method under nitrogen atmosphere at room temperature, using gamma rays from a Co-60. After grafting reactions, the polymer was then sulfonated in chlorosulfonic acid/1,2-dichloroethane (2 and 10\%) for 3 hours. The films were characterized before and after modification by calculating the degree of grafting (DOG), infrared spectroscopy (FT-IR), scanning electron microscopy (SEM), differential scanning calorimetry (DSC) and thermogravimetry (TG/DTG). DOG results show that grafting increases with dose, and varies enormously depending on the solvent used, with DOGs about 20 times greater in DMF than in toluene. It was possible to confirm the grafting of styrene by FT-IR due to the appearance of the new characteristic peaks and by the TG and DSC which exhibited changes in the thermal behavior of the grafted/sulfonated material. Sulfonated material was also characterized by ion exchange capacity (IEC) showed that both DOG and sulfonic acid concentration increase IEC values. Results showed that it is possible to obtain materials with ion exchange capacity of possible application as ionic polymer-metal composites.
\end{abstract}




\section{INTRODUÇÃO}

Ao longo dos últimos cem anos, os polímeros passaram a se fazer cada vez mais presentes nas mais variadas áreas substituindo matérias-primas clássicas como metais, cerâmicas, vidro, madeira e tecidos. Isso se deve ao fato de que, desde a síntese dos primeiros polímeros sintéticos, há pouco mais de um século, rapidamente a síntese de novos polímeros permitiu a obtenção de materiais com vasta gama de propriedades, muitas vezes capazes de igualar ou até mesmo superar o desempenho do material substituído por um dado polímero. Além disso, os polímeros apresentam vantagem de geralmente serem de mais fácil processamento, mais leves e mais baratos [1, 2].

Depois de permitir a substituição dos mais variados materiais e em diversos campos, estudos visando ao desenvolvimento de polímeros capazes de imitar estruturas animais, como músculos, passaram a ser realizados. Estudos de Osada e Hasebe em 1985 [3] relataram o desenvolvimento do primeiro modelo de um sistema mecanoquímico ativado eletricamente, constituído de gel polieletrólito reticulado e intumescido com água, o qual se movimentava de maneira reversível com aplicação de potencial elétrico. Outros estudos envolvendo hidrogéis como atuadores se seguiram, como os estudos de Hara et al. [4, 5].

Muitos estudos acerca do desenvolvimento de novos materiais que apresentassem capacidade de atuação se seguiram, com desenvolvimento de novos materiais e aplicações [6]. Esses materiais receberam o nome de atuadores poliméricos, entre os quais estão os compósitos ionoméricos de metalpolímero (IPMC - do inglês ionic polymer-metal composites), que são descritos como uma classe bastante promissora de atuadores poliméricos por apresentarem grandes deslocamentos em resposta a baixas voltagens, geralmente abaixo de 7 volts $[7,8]$.

Um dos principais polímeros utilizados na produção de IPMCs é o Nafion® (DuPont) [9], polímero também muito utilizado em células a combustível, sistemas de filtragem e em outras áreas em que se faz necessária a capacidade de troca iônica deste polímero [10,11]. O Nafion é um polímero de cadeia 
principal fluorada que apresenta grupos sulfônicos ligados a ramificações, o que Ihe confere propriedades interessantes: ao passo que a cadeia principal fluorada proporciona alta estabilidade físico-química, as ramificações com grupos sulfônicos apresentam hidrofilicidade e capacidade de troca iônica, que são características dos grupos iônicos. Entretanto, por se tratar de um polímero de elevado custo e apresentar propriedades mecânicas bastante reduzidas, o que restringe sua aplicação em áreas em que sejam necessárias propriedades mecânicas satisfatórias, como é o caso dos atuadores poliméricos, muitas pesquisas são realizadas para obtenção de materiais com propriedades semelhantes ou superiores para diferentes aplicações $[9,10]$.

Nesse sentido, polímeros fluorados são bastante estudados como matrizes poliméricas modificáveis, por apresentarem excelentes propriedades térmicas, químicas e mecânicas e podem ser modificados de diferentes formas para produzir novos materiais com capacidade de troca iônica, como o ataque de cadeias poliméricas quimicamente ou com ozônio [12, 13]. Mas há grande variedade de estudos envolvendo a enxertia induzida por radiação por parte de diferentes grupos ao redor do mundo, utilizando principalmente raios $X$, raios gama ou feixe de elétrons, como o Instituto Paul Scherrer (PSI) [14 20], o grupo do Dr. Nasef na Malásia [10, 21 - 27] ou ainda trabalhos envolvendo íons pesados acelerados, como nos trabalhos de Clochard e colaboradores [28]. Dentre as principais vantagens do uso da radiação como iniciadora de reações de polimerização está a de dispensar o uso de iniciadores e catalisadores. Neste caso, as naturezas químicas dos reagentes não são tão importantes como em reações convencionais de polimerização, permitindo a formação de materiais totalmente novos e em geral livres de resíduos ou contaminantes [14].

Dentre as áreas de aplicação de polímeros fluorados modificados, temos a produção de membranas trocadoras de íons para baterias e células a combustível, membranas para ultrafiltração e aplicações biomédicas, sensores e atuadores poliméricos $[10,11,14,33]$, entre outras. $O$ desenvolvimento de novos materiais se mostra interessante por permitir a produção de polímeros com variadas características, específicas para uma determinada aplicação. 


\section{OBJETIVO}

O objetivo deste trabalho é o estudo da enxertia de estireno em filmes de poli(fluoreto de vinilideno) (PVDF) induzida por radiação ionizante seguida de sulfonação, para o desenvolvimento de novas membranas com capacidade de troca iônica, aplicáveis na confecção de compósitos ionoméricos de metalpolímero (IPMCs). 


\section{REVISÃO BIBLIOGRÁFICA}

\subsection{Polímeros}

Polímero é uma palavra originada do grego, formada por "poli" (поһu), que significa muitos e "meros" ( $\mu$ ćpos), que significa partes ou unidades repetitivas. Assim, polímeros são moléculas grandes (também chamadas de macromoléculas) formadas por partes menores, os meros, que se repetem ligadas por ligações covalentes. Segundo Mano e Mendes [39], macromoléculas e polímeros apresentam conceitos semelhantes: todo polímero é uma macromolécula, mas nem toda macromolécula é um polímero, pois ambos se referem a moléculas de elevados pesos moleculares, entretanto, os polímeros apresentam unidades repetitivas, geralmente constituídas por átomos leves, como o carbono, hidrogênio, nitrogênio, oxigênio e silício.

As unidades de repetição recebem o nome de monômeros, são micromoléculas (moléculas pequenas) e devem estar aptas a reagir entre si formando cadeias. A reação que gera polímeros recebe o nome de polimerização e, para que a polimerização ocorra, é necessário que o monômero possua ao menos dois grupos reativos para permitir a formação de uma cadeia, além de exigir geralmente o uso de substâncias iniciadoras de reação e catalisadores. Como apresentado mais adiante, a radiação ionizante é capaz de induzir a formação de pontos reativos em moléculas e iniciar reações de polimerização ainda que tais moléculas não apresentem funcionalidade [40].

\subsubsection{Classificação dos polímeros}

Os polímeros podem ser classificados de diferentes maneiras, dependendo do critério avaliado para tal. Quanto à origem, um polímero pode ser natural (quando encontrado na natureza, como a celulose) ou sintético (quando produzido pelo homem). Quanto à variedade de monômeros utilizados na sua formação, podem ser classificados como homopolímero (com a repetição de apenas um monômero) ou copolímero (utilização de dois ou mais monômeros 
diferentes). Conforme seu comportamento mecânico, os polímeros podem ser divididos em borrachas, plásticos e fibras. Pode também existir a classificação quanto à reação de preparação do polímero, podendo ser de adição ou de condensação, e há também polímeros preparados pela modificação de outros polímeros por processos químicos. Os plásticos ainda podem ser classificados pela sua taticidade (estereoisomeria) e cristalinidade, entre muitas outras formas de classificação [1, 2, 39].

\subsubsection{Estereoisomeria}

Existem polímeros que apresentam grupos pendentes em sua estrutura, sendo que estes grupos podem variar suas posições espacialmente. Neste aspecto, os polímeros podem ser classificados como isotáticos, atáticos e sindiotáticos [2].

a) isotático: forma-se quando os grupos pendentes encontram-se sempre numa mesma posição espacial ao longo da cadeia polimérica;

b) sindiotático: quando os grupos laterais aparecem de forma alternada ao longo da cadeia polimérica;

c) atático: quando os grupos pendentes aparecem de forma aleatória ao longo da cadeia polimérica.

Essa diferença de posições dos grupos laterais (ilustrada na FIG. 1, [41]) pode interferir na forma com que as cadeias poliméricas se organizam, levando à formação de polímeros com diferentes propriedades; ainda que dois polímeros tenham sido preparados a partir do mesmo monômero, haverá grande diferença entre suas propriedades físico-químicas de acordo com suas taticidades $[1,2]$. 


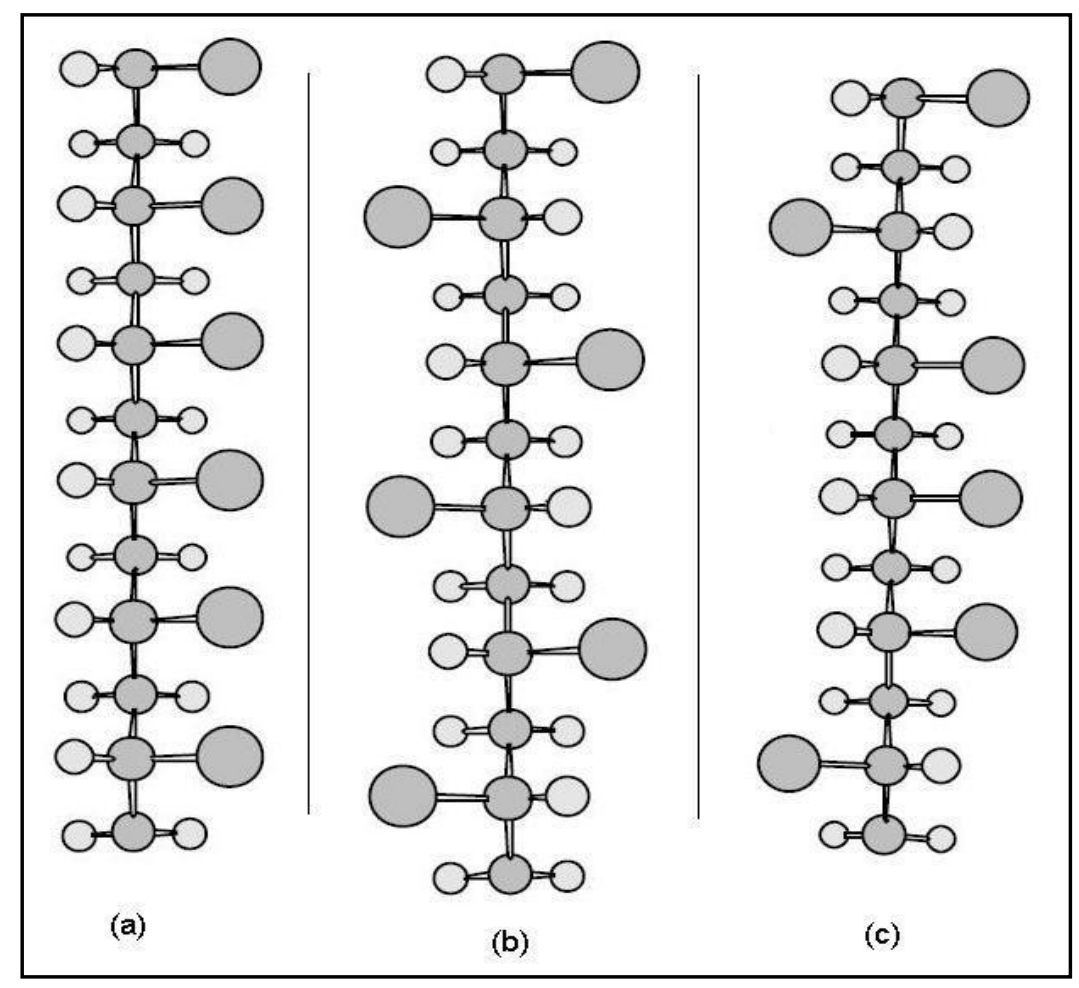

Figura 1 - Estereoisomerias. a) isotático; b) sindiotático; c) atático.

\subsubsection{Cristalinidade}

Cristalinidade de um polímero pode ser descrita como o grau com que as cadeias poliméricas se organizam e ocupam um determinado volume. $\mathrm{O}$ processo de cristalização de polímeros difere dos sólidos convencionais graças à natureza peculiar das longas cadeias que dificultam a livre movimentação dos átomos. As regiões cristalinas (organizadas), chamadas de cristalitos, podem conter imperfeições e estão interligadas com regiões desorganizadas (amorfas). Uma total cristalização é praticamente impossível, tendo em vista que geralmente apenas partes das moléculas se organizam formando cristais e, por essa razão, utiliza-se a terminologia de polímeros semicristalinos para polímeros que apresentam alto grau de cristalinidade [2, 39].

Um polímero é considerado amorfo quando suas cadeias não formam regiões organizadas, o que pode ocorrer por diferentes fatores, como a presença de grupos laterais que impeçam a organização de cadeias vizinhas, fazendo com que toda a massa polimérica permaneça de forma desorganizada. 
Os polímeros apresentam transições térmicas características, como a temperatura de transição vítrea $\left(T_{\mathrm{g}}\right)$, abaixo da qual apresentam-se vítreos (rígidos e quebradiços) e acima da qual as fases amorfas ganham mobilidade, tornando-os borrachosos; a temperatura de fusão cristalina $\left(T_{\mathrm{m}}\right)$, acima da qual regiões cristalinas se fundem e o polímero adquire estado fundido. A cristalinidade pode ser afetada por diversos fatores, como a linearidade das cadeias poliméricas, pois quanto menos ramificadas as cadeias mais fácil é o empacotamento, a taticidade, pois quanto mais regular a cadeia maior a facilidade de organização e a polaridade, pois a presença de grupos polares pode interferir na forma como as cadeias interagem entre si $[1,2]$.

\subsubsection{Homopolímeros e copolímeros}

Recebe o nome de homopolímero todo polímero originado com base em um único monômero. É geralmente produzido por reações de adição, como o polietileno (PE), polipropileno (PP) ou mesmo o poli(fluoreto de vinilideno) (PVDF). Os copolímeros, diferentemente, são produzidos pela polimerização de dois ou mais monômeros, chamados de comonômeros. Os copolímeros ainda podem se divididos em diferentes grupos de acordo com a disposição em que os monômeros aparecem na cadeia, podendo formar copolímeros aleatórios, alternados, em bloco ou ainda enxertados [39].

a) Copolímero ao acaso, aleatório ou estatístico

Neste grupo os meros não seguem uma ordem definida na cadeia polimérica, ou seja, os monômeros se ligam de forma aleatória durante a polimerização. Sendo A e B diferentes meros, temos como representação esquemática de parte de sua estrutura: 
b) Copolímero alternado

Refere-se ao polímero onde os meros aparecem de maneira alternada (organizadamente) na estrutura e em geral são formados quando da polimerização por condensação, como por exemplo a reação de um diácido com um diálcool ou com uma diamina:

A-B-A-B-A-B-A-B-A-B-A-B-A-B-A-B

c) Copolímero em bloco

Apresenta longas sequências de um dos meros ligando-se com grandes sequências do outro, de forma que cada um aparece em blocos de homopolímeros ligados entre si:

AAAAA BBBBBB AAAAAA BBBBB

d) Copolímero enxertado

Refere-se ao polímero que apresente em uma cadeia principal de um homopolímero (poli A) outra cadeia homopolimérica ligada covalentemente, formada por outro monômero (poli B):

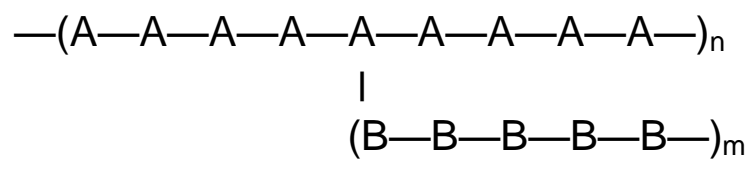

\subsection{Poli(fluoreto de vinilideno) - PVDF}

Os polímeros fluorados foram desenvolvidos para contornar alguns problemas de processabilidade do Teflon® - poli(tetrafluoroetileno) - PTFE - que o impedem de ser processado por métodos usuais, como injeção e extrusão.

O poli(fluoreto de vinilideno) (PVDF) é um polímero linear (cuja unidade repetitiva está representada na FIG. 2 [40]. É produzido a partir da polimerização 
do monômero fluoreto de vinilideno (VDF), o qual pode ser obtido de diferentes formas, sendo uma das mais utilizadas iniciada com a reação do acetileno com fluoreto de hidrogênio em presença de $\mathrm{BF}_{3}$ como catalisador formando 1,1difluoroetano, também chamado de CFC152. O CFC152 é então clorado para obtenção de 1-cloro-1,1-difluoroetano (CFC142) e posteriormente o CFC142 sofre abstração de cloreto de hidrogênio, originando o monômero vinilideno fluorado de acordo a FIG. 3 [42].

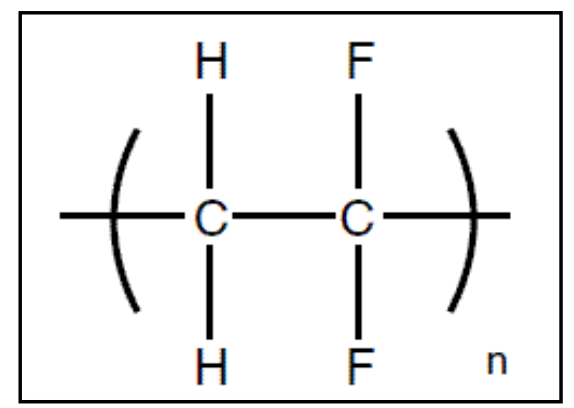

Figura 2 - Unidade repetitiva do PVDF.

O monômero VDF é um gás incolor sob pressão e temperatura ambientes, é inflamável e pode formar misturas explosivas com o ar. É usado tanto para produção do homopolímero PVDF quanto como um comonômero, juntamente com outros monômeros fluorados, como hexafluoropropileno (HFP), clorotrifluoroetileno (CTFE) ou tetrafluoroetileno (TFE) para produção de diversos elastômeros ou copolímeros fluorados. Pequenas quantidades de comonômeros, como os já citados podem ser adicionados durante a produção do PVDF para modificar sua cristalinidade ou outras propriedades [40, 42].

$$
\begin{aligned}
& \mathrm{HC} \equiv \mathrm{CH}+2 \mathrm{HF} \stackrel{\mathrm{BF}_{3}}{\longrightarrow} \mathrm{CH}_{3} \mathrm{CHF}_{2} \\
& \mathrm{CH}_{3} \mathrm{CHF}_{2}+\mathrm{Cl}_{2} \longrightarrow \mathrm{CH}_{3} \mathrm{CClF}_{2}+\mathrm{HCl} \\
& \mathrm{CH}_{3} \mathrm{CClF}_{2} \longrightarrow \mathrm{H}_{2} \mathrm{C}=\mathrm{CF}_{2}+\mathrm{HCl}
\end{aligned}
$$

Figura 3 - Etapas para produção do monômero VDF. 
As formas mais comuns de produção do PVDF são as polimerizações em emulsão e em suspensão aquosa. Em ambos os casos, são utilizados iniciadores com radicais livres e agentes de transferência de cadeia para controlar o peso molecular polimérico. Além destes, ainda podem ser usados agentes surfactantes e agentes dispersantes coloidais, dependendo do processo adotado. Geralmente resíduos desses agentes e iniciadores permanecem no polímero na forma de contaminantes [40].

O PVDF é um polímero semicristalino com cristalinidade variando geralmente entre 35 e $70 \%$, dependendo do processamento e do histórico termomecânico. As propriedades do PVDF podem ser influenciadas pela massa molar, distribuição da massa molar, irregularidades nas cadeias poliméricas e forma cristalina [41, 42]. O PVDF apresenta excelentes propriedades químicas e mecânicas, sendo resistente à maioria das substâncias químicas e solventes, mesmo ácidos e bases fortes [43].

Uma característica bastante peculiar apresentada pelo PVDF entre os polímeros sintéticos é o fato de apresentar um complexo polimorfismo cristalino, com quatro formas cristalinas distintas, chamadas de formas alfa, beta, gama e delta, que se formam de acordo com o método de processamento do polímero [42]. As fases mais comuns são as fases alfa e beta, formadas durante processamento convencionais, sendo que as outras duas são obtidas em condições específicas $[42,44,45,46,47]$.

\subsubsection{Fases cristalinas do PVDF}

A fase alfa (ou forma II) é caracterizada pela estrutura cristalina ortorrômbica e característica apolar, formando-se a partir do arrefecimento moderado ou rápido do fundido, também sendo formada a partir da evaporação de solvente. As cadeias estão dispostas em configuração trans-gauche (TGTG') de forma helicoidal, que permite maior afastamento entre os átomos de flúor. Torna-se apolar por seu empacotamento das cadeias originar momentos dipolares paralelos opostos (FIG. 4) [42, 44, 48,]. 


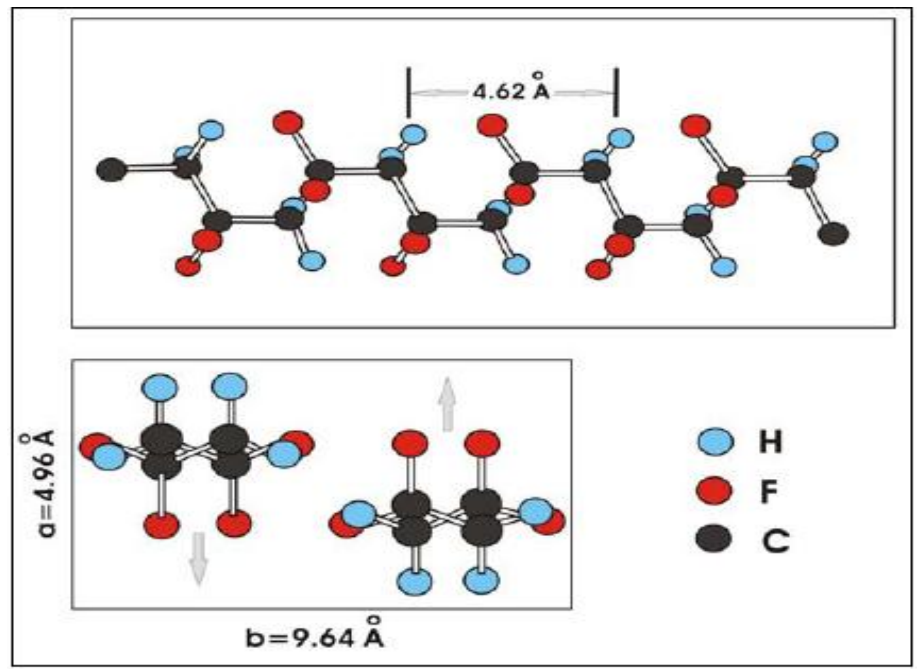

Figura 4 - Representação da estrutura e célula unitária do PVDF na forma alfa.

A fase beta, também conhecida como forma I, se caracteriza pelas ligações ziguezague planar, formada pelas ligações trans-trans (TT) na cadeia principal, normalmente produzida a partir do estiramento controlado da fase alfa. Trata-se de uma fase polar, com célula unitária ortorrômbica, na qual os átomos de flúor estão dispostos do lado oposto aos átomos de hidrogênio, como representado na FIG. 5 [42, 44] com um pequeno desvio causado pela deflexão de ligações carbono-flúor adjacentes.

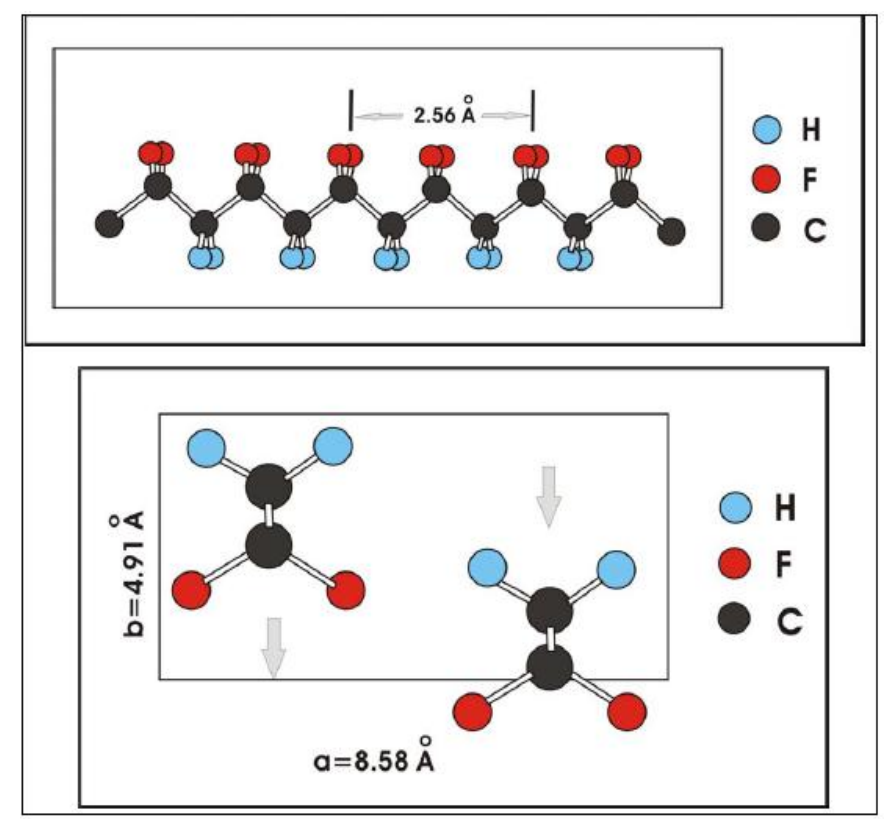

Figura 5 - Representação da estrutura e célula unitária do PVDF na forma beta. 
Esta fase apresenta acentuadas propriedades piezoelétricas e piroelétricas decorrentes do dipolo formado pela orientação dos átomos de flúor, tornando-a bastante estudada para aplicações em tecnologia, na forma de sensores, transdutores e atuadores poliméricos [44].

A fase gama pode ser obtida a partir da cristalização do polímero em solução ou do fundido, em temperaturas superiores a $155^{\circ} \mathrm{C}$ por períodos superiores a 6h. Essa fase é caracterizada pela presença de ligações gauche, intercaladas com três ligações trans (TTTGTTTG) propiciando a formação de célula unitária de estrutura monoclínica com característica polar, representadas na FIG. 6 (com hidrogênios omitidos) [44].

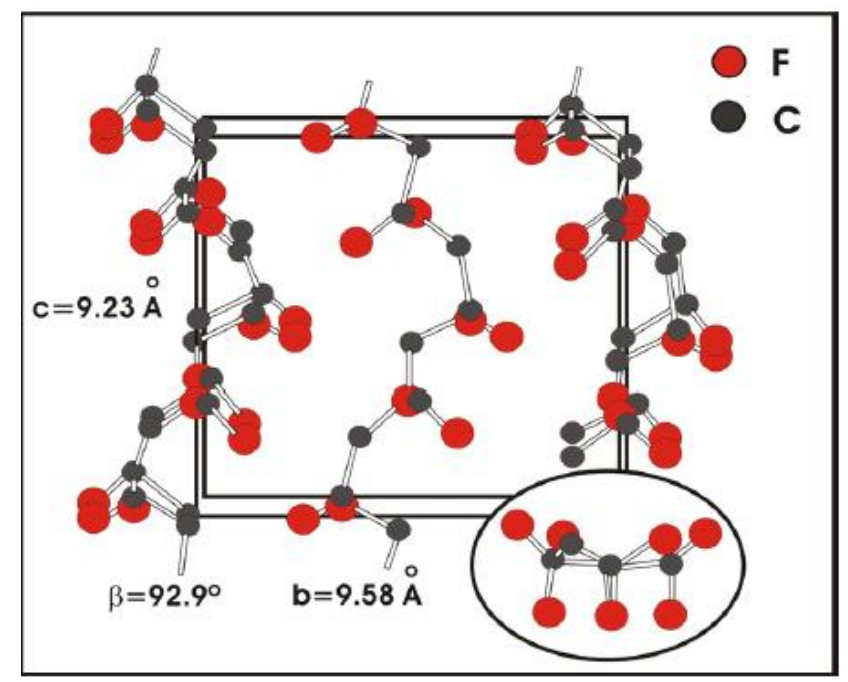

Figura 6 - Representação da estrutura e célula unitária do PVDF na forma gama.

A fase delta pode ser obtida quando da exposição da fase alfa a um intenso campo elétrico, que induz a inversão dos dipolos elétricos das cadeias organizadas na fase alfa, formando uma versão polarizada desta. Isso the confere estrutura conformacional idêntica à da fase alfa (TGTG'), com diferenças na forma como ocorre o empacotamento das cadeias, formando célula unitária ortorrômbica, representada na FIG. 7 [42, 44, 49]. 


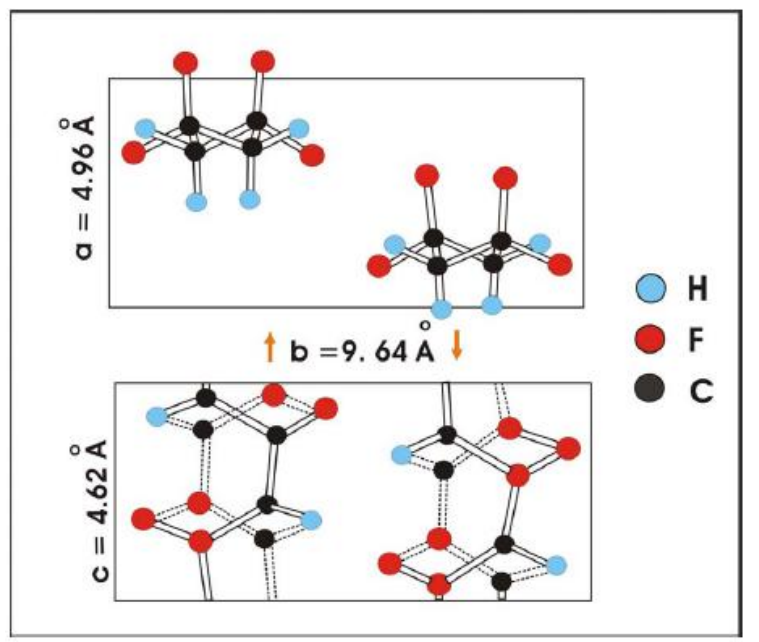

Figura 7 - Representação da estrutura e célula unitária do PVDF na forma delta.

Como dito anteriormente, as fases alfa e beta são as mais comumente encontradas em produtos de PVDF processado por técnicas convencionais de extrusão, por exemplo. Na FIG. 8 apresenta-se o espectro de infravermelho do filme de PVDF prístino utilizado nesse trabalho, na região entre 800 e $400 \mathrm{~cm}^{-1}$, no qual é possível notar os picos característicos de suas fases cristalinas [50, 51].

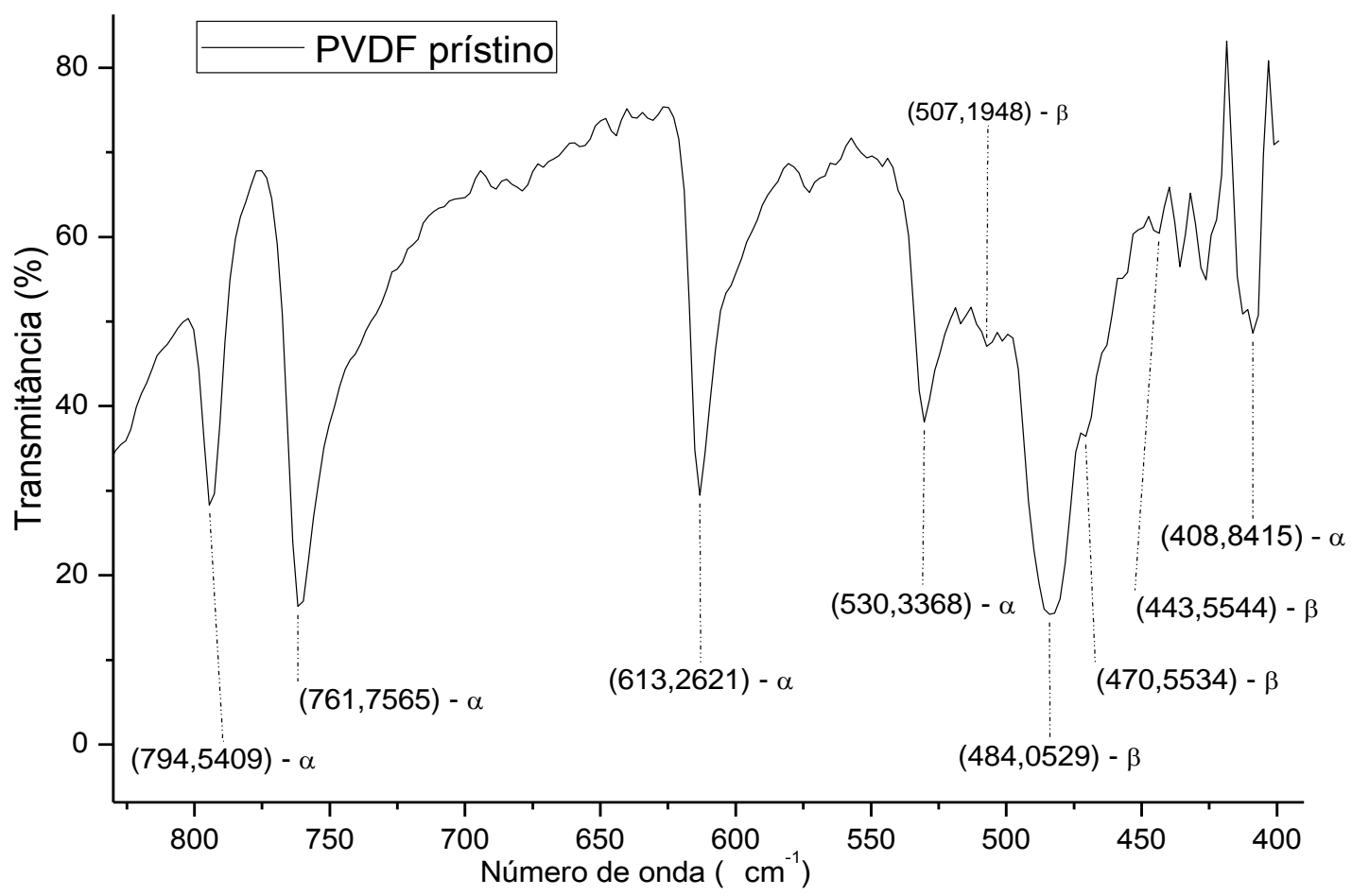

Figura 8-Espectros de FT-IR do PVDF utilizado neste trabalho, com os picos característicos das fases cristalinas. 


\subsection{Efeitos das radiações nos materiais}

As radiações mais utilizadas em estudos envolvendo efeitos das radiações são partículas aceleradas, como os feixes de elétrons, nêutrons ou átomos acelerados ou ondas eletromagnéticas como os raios $X$ e raios gama. As radiações interagem de diferentes maneiras com os materiais, transferindo energia e criando defeitos, por exemplo. Neste trabalho foi utilizada radiação gama, uma radiação eletromagnética ionizante de alta energia e que, por não apresentar carga elétrica nem massa, tem alto poder de penetração. A radiação eletromagnética pode interagir com a matéria de diferentes formas, sendo os três principais processos de atenuação da radiação o efeito fotoelétrico, efeito Compton e produção de pares [52, 54]:

a) Efeito fotoelétrico: ocorre principalmente com fótons de energias menores que $1 \mathrm{MeV}$ que interagem com átomos de elevado número atômico. Toda a energia do fóton é cedida para um único elétron do átomo, que é ejetado com energia igual à diferença entre as energias do fóton e de ligação do elétron ao átomo. A "vacância" gerada com perda do elétron ejetado é preenchida por outro elétron, de uma camada mais externa, com emissão de raios $X$ ou de elétrons Auger de baixa energia.

b) Efeito Compton: efeito mais comum, ocorrendo quando o fóton interage com um elétron das camadas mais externas, resultando na ejeção do elétron e no desvio do fóton incidente, com perda de energia, ou seja, a energia do fóton incidente é dividida entre o fóton e o elétron. Ocorre predominantemente o efeito Compton nas fontes de Cobalto-60, cujos fótons gerados apresentam energias entre $1 \mathrm{e}$ $10 \mathrm{MeV}$.

c) Produção de pares: envolve a completa absorção de um fóton nos arredores de um núcleo atômico ou, com menor frequência, de um elétron, com a formação de duas partículas: um elétron e um pósitron (partícula semelhante ao elétron que apresenta carga positiva). Cada partícula tem energia cinética igual à metade da 
diferença entre a energia do fóton e a energia de repouso das partículas. As duas partículas são mutuamente aniquiladas, originando dois raios gama de $0,51 \mathrm{MeV}$ cada, emitidos em direções opostas.

Entre os principais efeitos dessas interações nos materiais, os principais são a excitação e a ionização. A primeira ocorre quando a energia transferida para um ou mais elétrons não é suficiente para ejetá-lo(s), ou seja, para romper a ligação com o núcleo do átomo, resultando na passagem do elétron para camadas mais externas, formando produtos excitados. A segunda ocorre quando a energia transferida é maior que a energia de ligação do elétron com o núcleo, resultando na ejeção deste e formando um elétron livre e um radical, que pode ser um átomo ou uma molécula [29, 32, 54].

\subsubsection{Efeitos da radiação nos polímeros}

A interação da radiação ionizante com compostos orgânicos pode produzir espécies excitadas, cátions, ânions, radicais livres, entre outros. Quando os polímeros são irradiados, estas espécies formadas podem ficar aprisionadas por algum tempo, causando transformações denominadas efeitos pós-irradiação $[29,54,55]$.

A maioria dos estudos de efeitos das radiações em polímeros considera apenas as reações posteriores à formação de radicais livres [16, 25, 52, $53,54]$, sendo os estudos de polimerização induzidos por radiação focados nos monômeros que sofrem reação de polimerização ou nos polímeros que sofreram modificações induzidas por radiação.

Bradley [54] descreve que, com a irradiação de um polímero, podem ocorrer reações primárias e secundárias. A excitação e a ionização são reações primárias, sendo que na ionização um átomo ou molécula perde um elétron e na excitação este apenas passa para um estado de maior energia. As espécies primárias são muito reativas e instáveis, causando reações secundárias. Na FIG. 9, adaptada de Bradley [54], é apresentada de forma simplificada as principais reações primárias e secundárias induzidas pela radiação ionizante: 


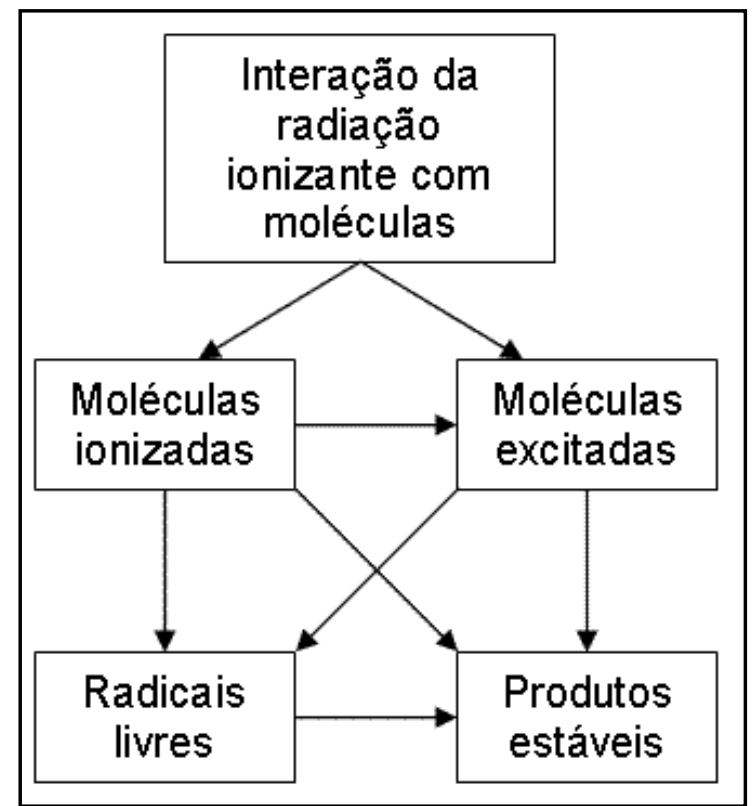

Figura 9 - Reações primárias e secundárias induzidas pela radiação ionizante.

Quando o PVDF é irradiado, há formação de diferentes radicais, entre os quais os principais são representados na FIG. 10. Quando armazenado adequadamente após a irradiação, alguns radicais formados podem permanecer ativos por vários dias [55].

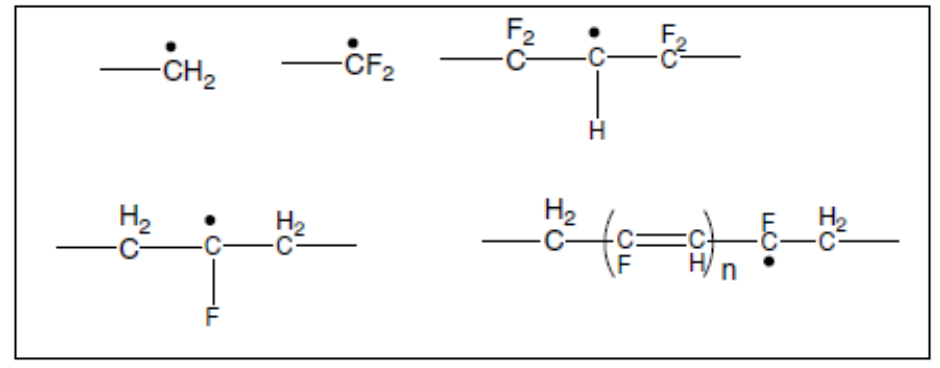

Figura 10 - Principais radicais formados pela irradiação do PVDF.

Podem ser desencadeados importantes processos de alteração das cadeias poliméricas como decorrência da interação das radiações ionizantes com os polímeros, como a liberação de subprodutos de radiólise, geralmente gasosos, cisão das cadeias ou reticulação. Alguns polímeros sofrem preferencialmente cisão das cadeias, com diminuição do peso molecular, outros, no entanto, sofrem reticulação, com aumento do peso molecular geralmente originado pela recombinação de radicais formados em cadeias vizinhas gerando uma rede tridimensional. A predominância de um ou de outro processo está relacionado 
com a composição do polímero. Quando o polímero irradiado entra em contato com um monômero, pode ocorrer a polimerização desse monômero, iniciando a formação de copolímero enxertado [29, 31, 52].

\subsubsection{Enxertia Induzida por Radiação}

A enxertia induzida por radiação vem sendo estudada constantemente nas últimas décadas, utilizando os mais variados polímeros, monômeros e fontes de radiação [10, 16, 28, 56, 57] Existem basicamente três métodos de realizar enxertia por irradiação, conhecidos como método da pré-irradiação, método da peroxidação e método da irradiação simultânea. As técnicas de enxertia têm como base a capacidade da radiação ionizante de criar sítios ativos na cadeia polimérica. As espécies são excitadas durante a irradiação e decaem para radicais que iniciam as reações de enxertia, cada uma diferindo na forma como o monômero é adicionado [30]:

\subsubsection{Método da pré-irradiação}

Também conhecido como método indireto, consiste na irradiação da matriz polimérica em atmosfera inerte sem a presença do monômero; somente depois de criados os sítios ativos o monômero é adicionado, puro ou em solução. A enxertia ocorre pela reação do monômero com os radicais livres e sítios ativos criados pela radiação na matriz polimérica.

\subsubsection{Método da peroxidação}

Também é um método indireto, mas, neste caso, a irradiação é realizada em presença de ar, desencadeando a formação de grupos peróxidos e hidroperóxidos, com a adição do monômero posteriormente à irradiação. Esses grupos são estáveis, desde que acondicionados corretamente, mas, com aumento da temperatura, são decompostos formando radicais livres que promovem o início da reação de enxertia. 


\subsubsection{Método da Irradiação simultânea}

Chamado de método direto, em que um polímero é colocado em contato com um monômero $\mathrm{M}$, que pode estar na forma líquida, de vapor ou diluído em solvente, e ambos são irradiados simultaneamente. A irradiação provoca a formação de sítios ativos na cadeia polimérica ou no monômero $M$, resultando assim na polimerização por enxertia. Dentre as principais vantagens deste método em relação aos anteriores, está a de maior simplicidade de processamento, embora como principal desvantagem haja o fato de ocorrer a homopolimerização do monômero na solução, podendo reduzir o rendimento da enxertia e exigindo a realização de lavagens para a remoção do homopolímero não enxertado [29, 30, 54].

O mecanismo de reação pode ser dividido em três etapas básicas: iniciação, propagação e terminação, como representado na FIG. 11 de maneira simplificada, a iniciação (a e b) e a propagação (c). Em (d) está representada a sequência de reações que ocorrem quando da irradiação do monômero, formando homopolímero, em que $\mathbf{P}$ representa um polímero, $\mathbf{P}^{{ }^{*}}$ um radical polimérico, $\mathbf{R}^{\bullet}$ um possível radical menor, $\mathbf{M}$ um monômero, $\mathbf{M}_{n+1}^{*}, \mathbf{P M}^{\bullet}$ e $\mathbf{P M}_{\mathbf{n}+1}^{*}$ radicais em crescimento. A terminação ocorre quando dois radicais próximos se combinam, interrompendo a propagação [29, 30, 31].

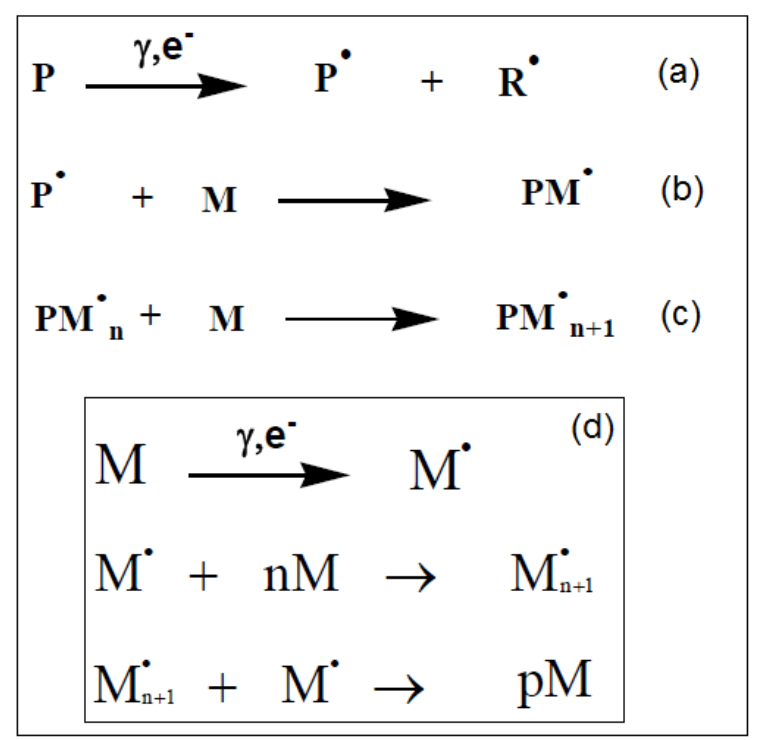

Figura 11 - Etapas da reação de polimerização induzida por radiação. 
Em muitos casos, o processo de enxertia, qualquer que seja o método utilizado, é um passo inicial, pois, dependendo do monômero enxertado, pode haver posterior tratamento químico específico para que sejam obtidas as propriedades desejadas, como as reações de sulfonação de estireno enxertado em polímeros fluorados para diferentes aplicações [11, 14, 33,58].

Em 1993 Sugiyama et al. [35] e Tsuneda et al. [36] estudaram a enxertia de monômeros contendo grupos sulfônicos $(\mathrm{SO} H \mathrm{H})$ em diferentes polímeros, como polipropileno (PP), polietileno (PE) e politetrafluoroetileno (PTFE), com feixe de elétrons, doses totais de 200 kGy, utilizando o método de pré-irradiação. Testaram diferentes concentrações de monômeros, em diferentes solventes. Foi demonstrada grande diferença quando da utilização de diferentes solventes assim como diferenças quanto às características de cada polímero.

Walsby et al.[59] estudaram a enxertia de estireno em filme de PVDF usando o método da pré-irradiação em atmosfera de $\mathrm{N}_{2}$. Entretanto, para temperatura ambiente, não relataram a ocorrência da ração desejada, sendo necessária a elevação da temperatura para promover tal reação. Foram utilizados feixes de elétrons com doses entre 25 e $150 \mathrm{kGy}$, com taxas de doses entre $330 \mathrm{e}$ $660 \mathrm{kGy} \mathrm{s}^{-1}$. Foram comparados os solventes tolueno e propanol em concentrações de $50 \%$ em volume de estireno. Relataram que o tolueno desfavorece a enxertia, ao passo que o propanol mantém o mesmo rendimento que $\mathrm{o}$ uso de estireno puro, em $70^{\circ} \mathrm{C}$ e doses de $100 \mathrm{kGy}$. Com as micrografias mostraram que a distribuição de flúor através da espessura da amostra enxertada em tolueno é diferente da enxertada em propanol, evidenciando a diferença proporcionada pelo solvente no que diz respeito ao avanço da frente de polimerização e homogeneidade da distribuição dos enxertos.

O grupo do Instituto Paul Scherrer [14 - 20,60] estudou a enxertia de diferentes monômeros em diferentes polímeros e por diferentes métodos de irradiação, como raios gama, raios $X$, raios UV e feixe de elétrons em diferentes doses e taxas de doses e descobriram que enxertias entre 20 e $30 \%$ são o melhor para células a combustível do tipo PEM. Um dos principais monômeros estudados é o estireno, por apresentar certa facilidade de modificação posterior, através de reações de sulfonação, por exemplo. 
O grupo do Dr. Nasef também descreve grande quantidade de experimentos envolvendo enxertia de estireno em diferentes polímeros fluorados, tanto pelos métodos indiretos quanto pelo método simultâneo, utilizando principalmente feixes de elétrons e raios gama [10, 21 - 27].

Linfan Li et al. estudaram a preparação de membranas trocadoras de prótons por meio da enxertia induzida por radiação em PVDF em pó e subsequente sulfonação, obtendo filmes por casting, o que permitiria obtenção de enxertos mais homogeneamente dispersos na matriz polimérica quando da formação dos filmes [37].

Grande parte dos estudos envolvendo enxertia de monômeros em polímeros, sejam elas iniciadas por irradiação ou de outras formas, também podem incluir reações posteriores para inserir grupos iônicos - caso o monômero já não os possua -, geralmente grupos sulfônicos [61].

Muitos autores, entre eles Flint e Slade [62], sugerem a estrutura do PVDF enxertado com estireno e sulfonado como apresentado na FIG. 12:

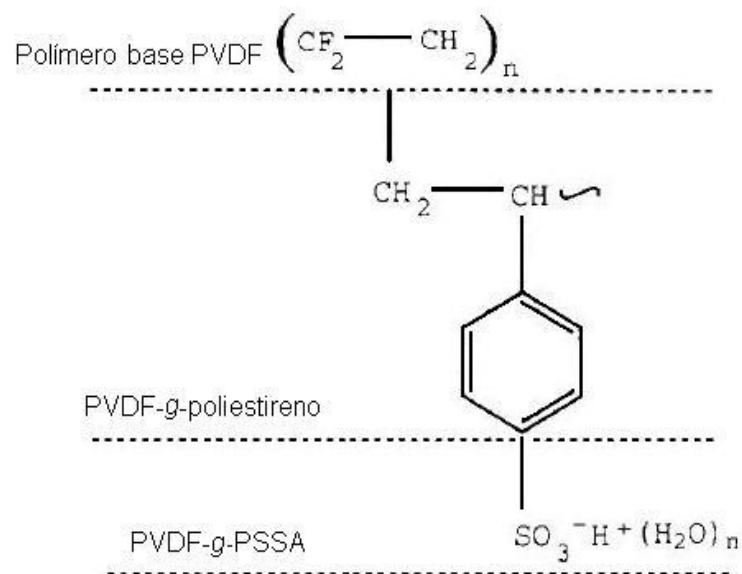

Figura 12 - Representação de estrutura de PVDF enxertado e sulfonado. 


\subsection{Atuadores poliméricos}

Os atuadores mais comuns são os motores de combustão, motores elétricos e dispositivos piezelétricos. Os motores de combustão são mais eficientes quando operando continuamente, mas não são indicados em movimentos intermitentes, como em válvulas ou sistemas de locomoção em robótica. Os motores elétricos apresentam baixa relação de torque por massa quando comparados á músculos naturais, tornando-os muito volumosos e pouco aplicáveis em dispositivos médicos, robótica ou aplicações que requeiram diminutos dispositivos. Já os piezelétricos apresentam grande densidade de força, mas proporcionam, contudo, pequenas deformações, geralmente menores que $0,1 \%$, exigindo intensa amplificação mecânica em casos em que grandes deslocamentos sejam necessários. Atualmente não há tecnologia alternativa amplamente viável para substituir ou simular a atuação de músculos naturais, sendo esse um importante motivo para pesquisas $[7,8]$.

Materiais poliméricos com a capacidade de se deformar quando estimulados de alguma forma recebem o nome de polímeros eletroativos (quando ativados eletricamente), atuadores poliméricos ou músculos artificiais. Existem diversos materiais poliméricos que podem responder de diferentes maneiras quando recebem estímulos externos, tais como variação do $\mathrm{pH}$ [63], do solvente [64] ou do campo/da corrente elétrico(a) [11,65]. Os polímeros eletroativos podem ser divididos em dois grupos distintos; os eletrônicos, ativados principalmente por campos elétricos e os iônicos, ativados pela movimentação ou difusão de íons através do material [7].

No primeiro grupo estão os chamados polímeros ferroelétricos, os polímeros eletroativos dielétricos, os elastômeros eletroativos enxertados, papéis eletroativos, elastômeros eletroviscoelásticos e os elastômeros líquidos cristalinos. No segundo grupo estão os géis poliméricos iônicos, os polímeros condutores, os nanotubos de carbono, os fluidos eletrorreológicos e os compósitos ionoméricos de metal-polímero [7]. Em geral, os do primeiro grupo precisam de campos elétricos da ordem de $\mathrm{kV}$, e os do segundo já exibem atuação com a aplicação de tensões entre 1 e 12 V. 


\subsubsection{Compósito ionomérico de metal-polímero (IPMC)}

Entre os diferentes tipos de atuadores poliméricos, estão os compósitos ionoméricos de metal-polímero (IPMCs), que são descritos como uma classe bastante promissora de atuadores poliméricos [8] por apresentarem grandes deslocamentos em resposta a baixas voltagens, geralmente abaixo de 7 volts.

Madden et al. [66] descrevem os IPMCs como uma matriz polimérica constituída de um polímero iônico entre dois eletrodos flexíveis, geralmente formado por partículas de metais nobres como ouro ou platina depositadas nas superfícies e no interior do polímero, embora a prata também seja estudada [67, $68,69$,$] .$

A FIG. 13 [11] esquematiza a flexão de um IPMC formado por polímero perfluorado com cadeias laterais iônicas em resposta a um potencial elétrico em que (a) representa as cadeias laterais, (b) os cátions hidratados, (c) as moléculas de água, (d) os ânions fixos e (e) os cátions móveis. As superfícies condutoras (eletrodos) foram formadas por deposição de nanopartículas de platina (Pt). Está representada a difusão de cátions e moléculas de água através do polímero [11]:
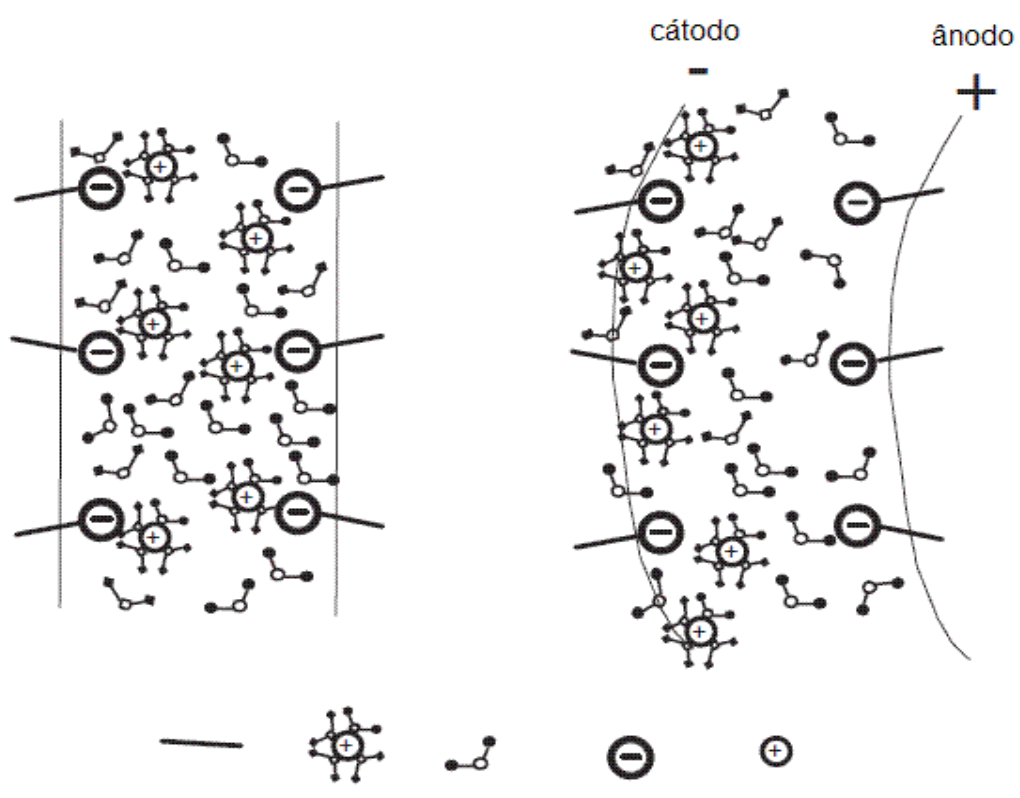

(a)

(b)

(c)

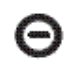

(d) $\odot$

(e)

Figura 13 - Representação da flexão e da difusão de cátions e de moléculas de água pelo polímero antes e depois da aplicação de potencial elétrico. 
A movimentação do IPMC se baseia na migração dos íons móveis através do polímero quando da aplicação de um potencial elétrico. Íons móveis migram em direção ao cátodo ou ao ânodo e arrastam consigo moléculas de solvente, geralmente água [7]. Uma vez que um dos lados do material passa a ter um acúmulo de moléculas de solvente, há o inchamento desta região, com contração do lado oposto, o que faz com que o material se dobre, como representado na FIG. 13.

Um dos principais polímeros utilizados na produção de IPMCs é o Nafion (DuPont) [9], também muito usado em células a combustível e em outras áreas em que a capacidade de troca iônica dessa classe de polímeros é necessária [66]. Por ser um polímero de elevado custo, muitas pesquisas são realizadas para obtenção de materiais com propriedades semelhantes ou superiores para diferentes aplicações.

Os autores Lee et al. [70] estudaram o uso de IPMCs baseados em Nafion para controle de sistemas de lentes móveis em câmeras de autofoco em aparelhos celulares para substituir os motores convencionalmente utilizados. Modificaram a superfície da membrana com plasma e relataram que é possível controlar e manter a posição do atuador/lente apesar de o deslocamento dos IPMC não ser linear. De acordo com esse trabalho, tal equipamento poderá ser comercializado dentro de pouco tempo e mostra como o desenvolvimento dessa área pode ser benéfica para o avanço de diversos campos, como informática, medicina, telecomunicações entre outros.

Um dos grupos com grande número de estudos acerca da produção e desenvolvimento dos IPMCs conta com os pesquisadores Shahinpoor e Kim [11, 71 - 75, 78], que descrevem as formas de produção dos ionômeros, a produção de IPMCs a partir desses polímeros, a importância da metalização nas propriedades finais do compósito, novas formas de confecção que garantam maior amplitude ou complexidade de movimentações, entre outras.

Han et al. estudaram a aplicação de polímeros com capacidade de troca iônica produzidos por enxertia induzida por radiação em polímeros fluorados como IPMCs e descreveram as diferenças entre as propriedades obtidas com os diferentes polímeros [76]. 
Os procedimentos mais amplamente adotados para a deposição dos eletrodos metálicos no interior e nas superfícies do ionômero são descritos por Oguro [79], embora algumas pequenas alterações sejam feitas por outros autores $[11,70,71,76]$. Uma etapa importante consiste na abrasão superficial, quer seja com uma lixa ou com jato de areia, para conferir à superfície uma rugosidade adequada para a adesão da camada metálica e aumentar a área de contato, permitindo assim melhor eficiência. 


\section{METODOLOGIA}

\subsection{Materiais utilizados}

Para a realização deste trabalho, foram utilizados filme de PVDF comercial fornecido pela Goodfellow com espessura de 125 micrômetros $(0,125$ $\mathrm{mm}$ ); estireno 99\% com inibidor 4-terc-butilcatecol fornecido pela Huntsman Ltda; tolueno e $\mathrm{N}, \mathrm{N}$-dimetilformamida (DMF), ambos PA $(99,8 \%)$ fornecidos pela Merck; etanol PA (99,8\%) Vetec; ácido clorossulfônico PA (97\%) fornecido pela Acros Organic; 1,2-dicloroetano PA(99\%) Labsynth; cloreto de sódio PA (99\%) Vetec; hidróxido de sódio PA (97\%) Labsynth; ácido sulfúrico PA (99-95\%) Merck; água oxigenada $30 \%$ Merck; nitrato de prata PA $(99,8 \%)$ Vetec; boroidreto de sódio PA $(99,5 \%)$ Vetec; citrato de sódio PA (99,5\%) Vetec; amostra de Nafion 117 com espessura de 0,100 mm (Dupont); água destilada; gases nitrogênio e oxigênio White Martins, ambos com pureza de 99,9999\% para a realização das análises térmicas e purga das soluções com $\mathrm{N}_{2}$. Todos os reagentes foram utilizados como recebidos, sem tratamentos prévios ou purificações adicionais.

\subsection{Preparação das amostras}

Filmes de PVDF foram cortados com dimensões aproximadas de $3 \times 5$ $\mathrm{cm}^{2}$, lavados com etanol e secos em estufa até peso constante. Foram então inseridos em frascos de vidro contendo cerca de $50 \mathrm{~mL}$ de soluções de estireno/tolueno ou estireno/DMF (ambas 1:1 v/v). Foi utilizado papel-filtro como separador entre os filmes, para impedir que as amostras ficassem em contato com o vidro e entre si, permitindo assim uma distribuição mais homogênea das soluções ao redor dos filmes. As soluções foram purgadas com gás nitrogênio por cerca de 10 minutos e os frascos foram selados e irradiados com radiação gama. As irradiações foram realizadas na empresa CBE-Embrarad, em Cotia, (São Paulo, SP), em um irradiador com fonte de cobalto (cobalto-60), com taxa de dose de $5 \mathrm{kGy} \cdot \mathrm{h}^{-1}$ (monitorado com dosímetro Harwell Red Perspex 4034) e doses totais entre 1 e 100 kGy em temperatura ambiente. 
Após as irradiações, os frascos foram mantidos selados em temperatura ambiente por sete dias, após os quais os filmes foram lavados em sistema Sohxlet com tolueno para remoção de resíduos da solução e homopolímero formado, secos em estufa a vácuo a $70 \stackrel{\circ}{\mathrm{C}}$ até pesos constantes e caracterizados em seguida. Para a realização das caracterizações do poliestireno (PS), o monômero estireno utilizado neste trabalho foi aquecido a $120^{\circ} \mathrm{C}$ durante 3 horas para promover sua polimerização. O PS sólido obtido após o resfriamento foi caracterizado por FT-IR, TG/DTG e DSC.

A sulfonação das amostras enxertadas foi realizada com soluções de ácido clorossulfônico em 1,2-dicloroetano nas concentrações de $2 \%$ ou $10 \%$ (v/v) por um período de 4 horas em temperatura ambiente, metodologia semelhante à usada por vários autores, embora outros a realizem de forma diferente [10, 14, 77]. Após a sulfonação os filmes foram imediatamente lavados com água destilada até $\mathrm{pH}$ constante ser atingido e caracterizados novamente.

Para a metalização das superfícies das amostras sulfonadas foram preparadas solução de nitrato de prata $\left(\mathrm{AgNO}_{3}\right)$ contendo $5 \mathrm{mg} \cdot \mathrm{mL}^{-1}$, solução de boroidreto de sódio $\left(\mathrm{NaBH}_{4}\right) 50 \mathrm{~g} \cdot \mathrm{L}^{-1}$, solução de $\mathrm{NaOH}$ em concentração de 0,05 mol. $L^{-1}$, solução de citrato de sódio com concentração de 0,04 mol.L ${ }^{-1}$, todas com água destilada. A metalização foi realizada a partir da adaptação de diferentes métodos utilizados na literatura [6, 7, 8, 9, 11, 78]. Grande parte dos autores utiliza sais e complexos de platina ou ouro para a deposição de partículas metálicas que formariam os eletrodos, entretanto, tendo em vista o custo elevado desses materiais, bem como a frequente utilização de hidrazina [79],material tóxico e explosivo, optou-se pelo uso de prata, na forma de nitrato de prata, com o processo de redução à prata metálica adaptado dessas fontes, de forma a utilizar materiais de reduzida toxicidade, como o boroidreto de sódio e o citrato de sódio.

Para a primeira etapa de deposição, as amostras sulfonadas deixadas por cerca de 12 horas em solução de $\mathrm{AgNO}_{3}$ em temperatura ambiente para que íons $\mathrm{Ag}^{+}$fossem trocados pelos íons $\mathrm{H}^{+}$presentes nos grupos iônicos do polímero sulfonado. Após esse primeiro banho, as amostras foram lavadas com água destilada e imersas em solução de agente redutor forte, $\mathrm{NaBH}_{4}$, para a redução dos íons $\mathrm{Ag}^{+}$a $\mathrm{Ag}^{0}$ em temperatura ambiente, durante 3 horas, sendo possível 
notar, desde o inicio da imersão, o escurecimento das amostras, evidenciando a formação de partículas de prata. Em seguida, as amostras foram lavadas com água destilada e imersas em ácido sulfúrico $0,1 \mathrm{~N}$ aquecido a $60^{\circ} \mathrm{C}$ por cerca de 8 horas para a remoção dos cátions $\mathrm{Na}^{+}$(presentes na solução redutora) e novamente lavadas com água destilada até $\mathrm{pH}$ constante, e repetiram-se todas as etapas por 5 vezes.

Posteriormente, foi realizada deposição de partículas de prata superficialmente de maneira diferente das anteriores; foi utilizada a mesma solução de nitrato de prata, mas, na etapa de redução, foi utilizado um agente redutor fraco, o citrato de sódio. Segundo alguns autores [6, 7, 8, 9, 11, 78], a lenta adição de redutor fraco faz com que haja formação de eletrodos externos ao polímero, de maneira que a aplicação de campo elétrico seja mais eficiente. Depois dessa etapa, as amostras foram lavadas com água destilada aquecida durante 2 horas, lavadas com ácido sulfúrico $0,1 \mathrm{~N}$ e imersas em solução de cloreto de sódio para promover a troca iônica dos cátions dessa solução pelos hidrogênios das membranas, na forma ácida. Para a realização dos testes e comparação, foi preparada da mesma forma uma membrana de Nafion $117 \mathrm{com}$ $0,100 \mathrm{~mm}$ de espessura. Todas as membranas foram submetidas a correntes contínuas de 1,5 a $4,5 \mathrm{~V}$ e $1000 \mathrm{~mA}$, presas em um suporte isolante com contatos elétricos de cobre, como ilustra a FIG. 14:

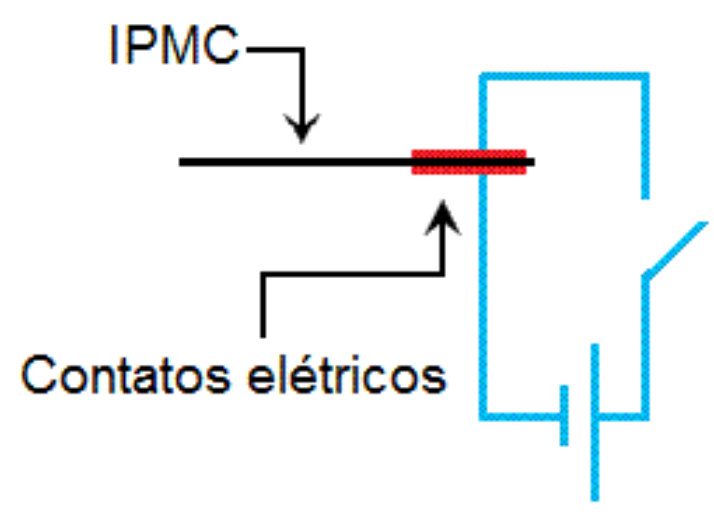

Figura 14 - Ilustração do sistema utilizado para testar a movimentação dos IPMCs. 


\subsection{Caracterizações}

\subsubsection{Grau de enxertia (DOG)}

O grau de enxertia (DOG, do inglês degree of grafting) foi calculado de acordo com a equação $(A)[10]$ :

$$
\operatorname{DOG}(\%)=\left[\left(m_{f}-m_{i}\right) / m_{i}\right] \times 100
$$

, em que $m_{f}$ e $m_{i}$ são as massas final e inicial das amostras, respectivamente.

\subsubsection{Intumescimento do PVDF nas soluções}

Antes da realização da enxertia, amostras de PVDF foram lavadas com etanol e secas em estufa até massa constante. Em seguida, foram imersas nos solventes e nas soluções utilizadas para verificar como cada solvente afetaria a penetração do monômero na matriz polimérica. Foram pesadas em intervalos de tempo até um período total de $24 \mathrm{~h}$ (1440 minutos) para a determinação do grau de intumescimento (ou inchamento). O resultado foi obtido usando-se a equação (B), presente na norma ASTM D 570 [80] que descreve o procedimento para o intumescimento com água. Neste trabalho foi feita uma adaptação deste método e, no lugar do intumescimento com água, foi calculado o intumescimento com os solventes e com as soluções.

$$
\text { Intumescimento }(\%)=\left[\left(\mathrm{m}_{\mathrm{s}}-\mathrm{m}_{\mathrm{d}}\right) / \mathrm{m}_{\mathrm{d}}\right] \times 100
$$

, na qual $m_{s}$ é a massa do polímero intumescido e $m_{d}$ a massa do polímero seco.

\subsubsection{Espectrometria vibracional no infravermelho (FT-IR)}

Os espectros de infravermelho ( $\mathrm{FT}-\mathrm{IR}$ ) foram obtidos em equipamento Thermo Nicolet 6700 Smart Diamond ATR de 4000 a $400 \mathrm{~cm}^{-1}$ com 64 varreduras e resolução de $4 \mathrm{~cm}^{-1}$. 


\subsubsection{Termogravimetria (TG/DTG)}

Amostras de cerca de $10 \mathrm{mg}$ dos materiais foram inseridas em cadinhos de alumina para que medidas termogravimétricas (TG/DTG) fossem obtidas em termobalança Mettler-Toledo TGA / SDTA 851 com faixa de temperatura de 25 a $700 \stackrel{\circ}{\circ}$, taxa de aquecimento de $10 \stackrel{\circ}{\circ} \mathrm{min}^{-1} \mathrm{em}$ atmosfera inerte (nitrogênio) ou atmosfera oxidativa (oxigênio) com fluxo de $50 \mathrm{~cm}^{3}$ por minuto.

\subsubsection{Calorimetria exploratória diferencial (DSC)}

Medidas de DSC foram realizadas em equipamento Mettler-Toledo 822, com programa de aquecimento de 25 a $250 \stackrel{\circ}{\circ}$, isoterma em $250 \stackrel{\circ}{\circ} \mathrm{C}$ por dez minutos, resfriamento até $-50{ }^{\circ} \mathrm{C}$ e novo ciclo de aquecimento até $250 \stackrel{\circ}{\circ} \mathrm{C}$, sempre com taxa de aquecimento de $10 \stackrel{\circ}{\circ} \mathrm{C} \mathrm{min}^{-1}$ em atmosfera de nitrogênio e apenas a segunda varredura foi considerada.

Os valores de cristalinidades dos materiais foram obtidos diretamente no computador, por meio do software STAR ${ }^{e}$ aplicando a equação (C) [81]:

$$
\mathrm{C}=\left(\Delta H_{f} / \Delta H_{f}^{\circ}\right) \times 100(\%)
$$

, em que $C$ é a cristalinidade, $\Delta H_{f}$ é o calor de fusão da amostra e $\Delta H_{f}^{\circ}$ é o calor de fusão do polímero teoricamente $100 \%$ cristalino. Para os cálculos das cristalinidades, o valor utilizado de $\Delta H_{f}^{\circ}$ do PVDF foi $104,5 \mathrm{J.g}^{-1}$ [82].

\subsubsection{Cálculo da capacidade de troca iônica (IEC)}

Após a sulfonação, a capacidade de troca iônica (do inglês, íon exchange capacity, IEC) foi calculada por meio de titulação de neutralização.

O IEC foi determinado mergulhando-se as amostras sulfonadas na forma ácida em uma solução $3 \mathrm{M}$ de $\mathrm{NaCl}$ por cerca de 15 horas sob agitação constante e em temperatura ambiente. Os íons $\mathrm{H}^{+}$liberados na solução (trocados por $\mathrm{Na}^{+}$da solução) foram titulados com solução padrão de $\mathrm{NaOH} 0,052 \mathrm{M}$ até $\mathrm{pH}$ 
7. Baseado no volume de $\mathrm{NaOH}$ consumido na titulação o IEC pode ser calculado em unidade de massa (meq. $\mathrm{g}^{-1}$ ) da massa seca da amostra titulada.

A capacidade de troca iônica experimental foi calculada de acordo com a equação (D) [38]:

$$
\mathrm{IEC}_{\mathrm{E}}=\left(\mathrm{C}_{\mathrm{NaOH}} \times \mathrm{V}_{\mathrm{NaOH}}\right) / \mathrm{M}_{\mathrm{pol}}
$$

, em que $\mathrm{C}_{\mathrm{NaOH}}$ e $\mathrm{V}_{\mathrm{NaOH}}$ representam a concentração e o volume da solução de $\mathrm{NaOH}$ utilizada na titulação, respectivamente e $\mathrm{M}_{\text {pol }}$ a massa seca de polímero utilizada.

Supondo que quando ocorre a sulfonação cada anel de estireno contenha um grupo sulfônico, o valor do DOG poderia ser diretamente relacionado com os valores de IEC, relação esta é dada pela equação (E)

$$
\mathrm{IEC}_{\mathrm{T}}=\left(10^{3} \times \mathrm{D} / \mathrm{M}_{\mathrm{E}}\right) /\left\{100+\mathrm{D}+\left[\left(\mathrm{D} / \mathrm{M}_{\mathrm{E}}\right) \times \mathrm{M}_{S}\right]\right\}
$$

, em que D é o DOG obtido, $M_{E}$ é a massa molar do estireno (104 g/mol) e $M_{S}$ é a massa molar do grupo sulfônico (80 $\mathrm{g} / \mathrm{mol})$ [83]. Simplificando a equação (E) temos a equação $(F)$ que expressa o valor teórico do IEC:

$$
\mathrm{IEC}_{\mathrm{T}}=(9,62 \times \mathrm{D}) /[100+(1,77 \times \mathrm{D})]
$$

\subsubsection{Microscopia eletrônica de varredura (MEV)}

As micrografias foram obtidas em equipamento Phillips $\mathrm{XL} 30 \mathrm{com}$ ampliações de cerca de 250x, 4000x e 6000x [84]. As amostras de filmes de PDVF prístino, enxertado em soluções de estireno/DMF e estireno/tolueno bem como dos filmes sulfonados após enxertados foram cobertas com ouro em um Sputter Coater BAL-TEC SCD 050, ambos instalados no CCTM/IPEN-SP.

\subsubsection{Espectroscopia de energia dispersiva (EDS)}

Foram obtidos espectros de EDS em equipamento Phillips XL 30. As amostras de filmes de PDVF prístino, enxertado em soluções de estireno/DMF e 
estireno/tolueno bem como dos filmes sulfonados depois de enxertados foram recobertas com ouro em um Sputter Coater BAL-TEC SCD 050, ambos instalados no laboratório de microscopia da Escola Politécnica da USP. 


\section{RESULTADOS E DISCUSSÃO}

\subsection{Grau de enxertia (DOG)}

Os resultados de enxertia do estireno no PVDF são apresentados na FIG. 15, calculados por meio da equação $(A)$ quando do uso do tolueno e da DMF como solventes.

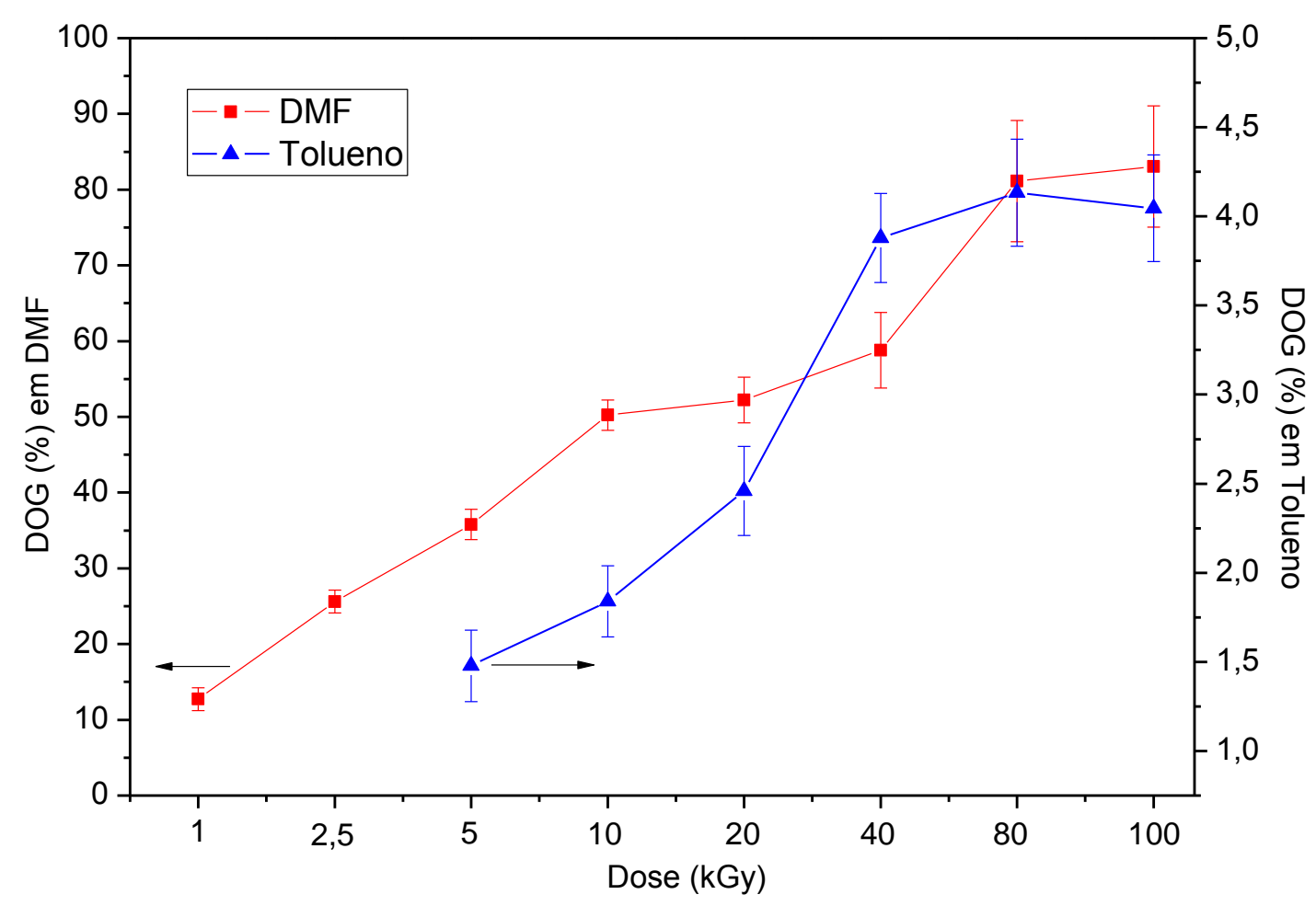

Figura 15 - Grau de enxertia para diferentes doses e com ambos os solventes.

É perceptível por meio da FIG. 15 o comportamento da reação de enxertia associada à dose de irradiação à qual foi exposto 0 material. Independentemente do solvente utilizado, o aumento da dose corresponde a um aumento do grau de enxertia. Tal comportamento pode ser explicado pelo fato de maior dose de radiação gerar maior número de espécies reativas e consequentemente maior formação de ligações com o monômero.

Fica também evidente a grande diferença na enxertia associada ao uso dos diferentes solventes, como já descrito por diferentes autores ao estudarem diferentes conjuntos matriz/monômero/solvente $[10,30,33,60]$. O tolueno não 
permite enxertias maiores que $5 \%$, fato já observado anteriormente por Geraldes e colaboradores [85] em condições semelhantes. Para a DMF os maiores resultados chegam próximos de $90 \%$ para as doses mais altas. Essa diferença pode ser atribuída a diferentes fatores relacionados aos solventes, uma vez que todas as amostras estiveram sujeitas às mesmas condições de irradiação.

Um desses fatores pode ser o parâmetro de solubilidade do polímero, do monômero e do copolímero formado em relação aos solventes. A DMF é notoriamente um solvente do PVDF em certas condições [42, 47], ao passo que o tolueno não. Isso permite um melhor intumescimento do polímero em presença de DMF, aumentando a distância entre as cadeias e permitindo uma maior e mais homogênea penetração do monômero no interior da massa polimérica. Esse fato pode ser observado na FIG. 16, na qual apresenta-se os valores de intumescimento do PVDF utilizado quando imerso nos solventes e nas soluções utilizadas por período de até 24 horas (1440 minutos):

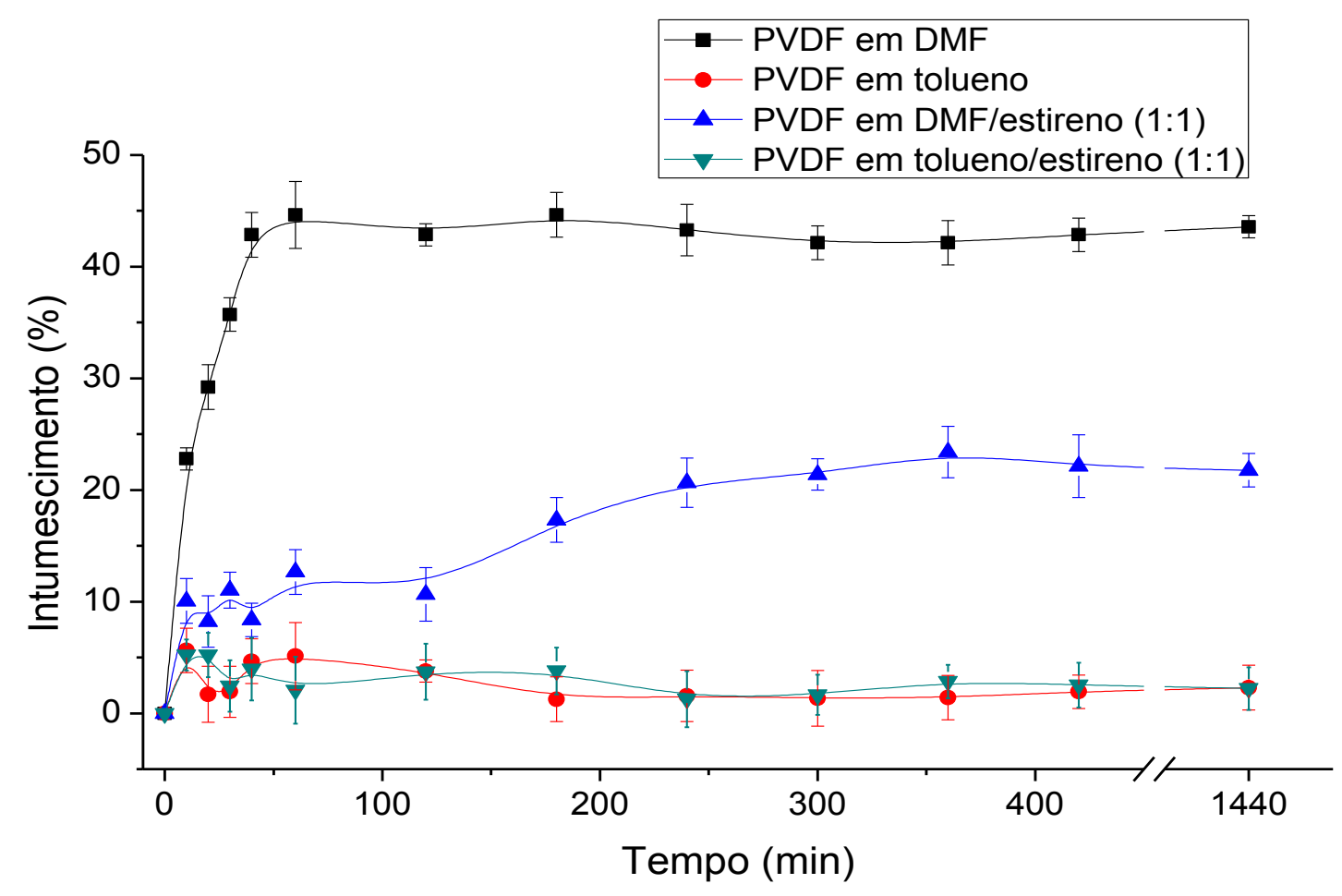

Figura 16 - Intumescimento do PVDF em DMF, tolueno e nas soluções destes com estireno. 
Podemos notar que na solução de DMF/estireno o filme intumesce cerca de dez vezes mais quando comparado com o filme imerso na solução de tolueno/estireno (nesta solução, algumas amostras apresentaram intumescimento praticamente nulo). Essa diferença pode ser causada por uma maior penetração do solvente e do monômero no interior do polímero, permitindo que quando da irradiação do material o monômero esteja mais abundantemente disponível, apto a reagir com os radicais formados, o que explica em parte o maior rendimento de enxertia obtido com o uso da DMF como solvente do monômero.

Entretanto, essa diferença de solubilidade não poderia ser a única responsável pela grande diferença encontrada na enxertia, sendo que outros fatores também merecem atenção, como a formação de subprodutos da radiólise dos solventes durante as irradiações. O tolueno poderia formar principalmente subprodutos menos reativos, como hidrogênio gasoso e grupos metila, já a DMF formaria vários subprodutos oxigenados e nitrogenados bastante reativos que poderiam facilmente atacar as cadeias da matriz polimérica e o monômero, desencadeando maior formação de grupos reativos [86, 87, 88] e contribuindo para o aumento do rendimento de enxertia.

Outro fato que deve ser considerado é a diferença entre as constantes de transferência de cadeia do polímero para o monômero e solventes utilizados, que têm participação importante na reação de enxertia, determinando o tamanho e a distribuição das cadeias enxertadas. Embora os valores mudem de acordo com o meio, pressão e com a temperatura, sabe-se que o valor da constante decresce na ordem DMF > estireno > tolueno. Baseados nisso, podemos dizer que possivelmente a DMF favoreça a formação de enxertos mais curtos e mais numerosos que o tolueno, o que talvez explique a formação dos aglomerados na superfície das amostras enxertadas em tolueno, que podem ser formados por longas cadeias de poliestireno [40, 89 - 94].

É descrito na literatura que a enxertia ocorre nas regiões amorfas dos polímeros [29, 30]. Assim, acredita-se que a fase cristalina tenha sido pouco afetada uma vez que não houve dissolução do PVDF quando imerso em solução estireno/DMF em temperatura ambiente antes ou durante as irradiações. 
Com as cadeias poliméricas das regiões amorfas mais afastadas pela presença da DMF, os radicais formados no interior do polímero poderiam reagir prontamente com moléculas do monômero próximas. Já o tolueno, por não favorecer a penetração do monômero, favoreceria apenas uma enxertia mais superficial e em menor grau. Como o processo de polimerização parece ocorrer por fronteira, as camadas mais externas dos filmes começam a ficar ricas em poliestireno e este passa a dificultar a penetração de monômeros para as camadas mais internas. Esse fato pode ser confirmado por meio da análise por microscopia eletrônica de varredura (MEV).

\subsection{Microscopia eletrônica de varredura (MEV)}

Estão apresentadas nas FIG. 17, 18 e 19 as micrografias de superfícies do PVDF prístino, PVDF enxertado em solução contendo DMF e PVDF enxertado em solução contendo tolueno, respectivamente, com diferentes ampliações e em diferentes doses:
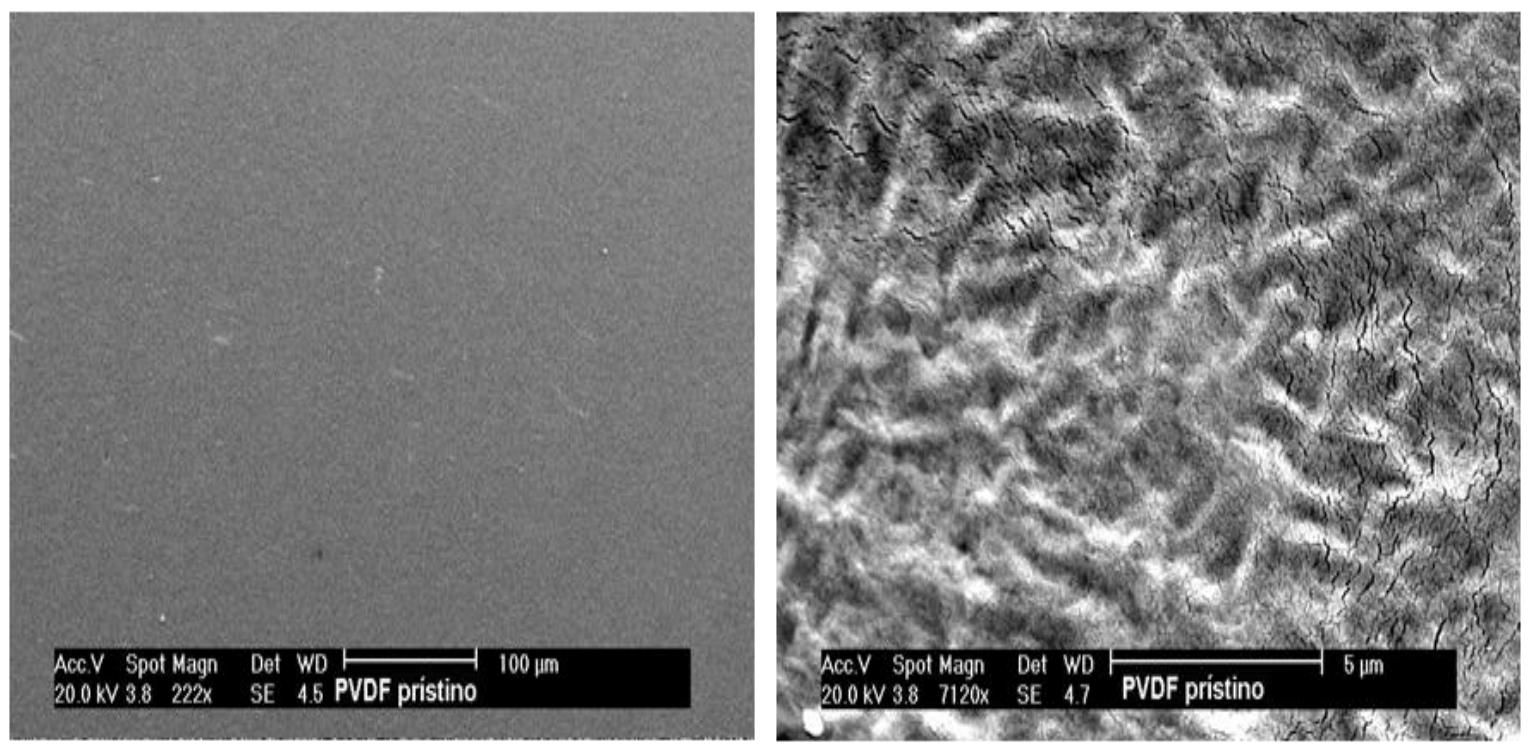

Figura 17 - Micrografias de superfície de filme de PVDF prístino. 
Podemos notar a clara diferença de ação entre os dois solventes no âmbito da morfologia do material polimérico resultante. Quando o PVDF é enxertado em solução de estireno/DMF, qualquer que seja a dose de radiação utilizada, apresenta superfície bastante semelhante à do polímero prístino, ainda que apresente enxertias tão altas quanto 60\% (como é o caso de $40 \mathrm{kGy}$ ), o que evidencia uma distribuição homogênea do estireno pelo interior e na superfície do filme. Já para as amostras enxertadas em soluções de estireno/tolueno, há uma aparente dificuldade do estireno em penetrar na matriz polimérica, formando uma camada de poliestireno aglomerado na superfície do PVDF. 

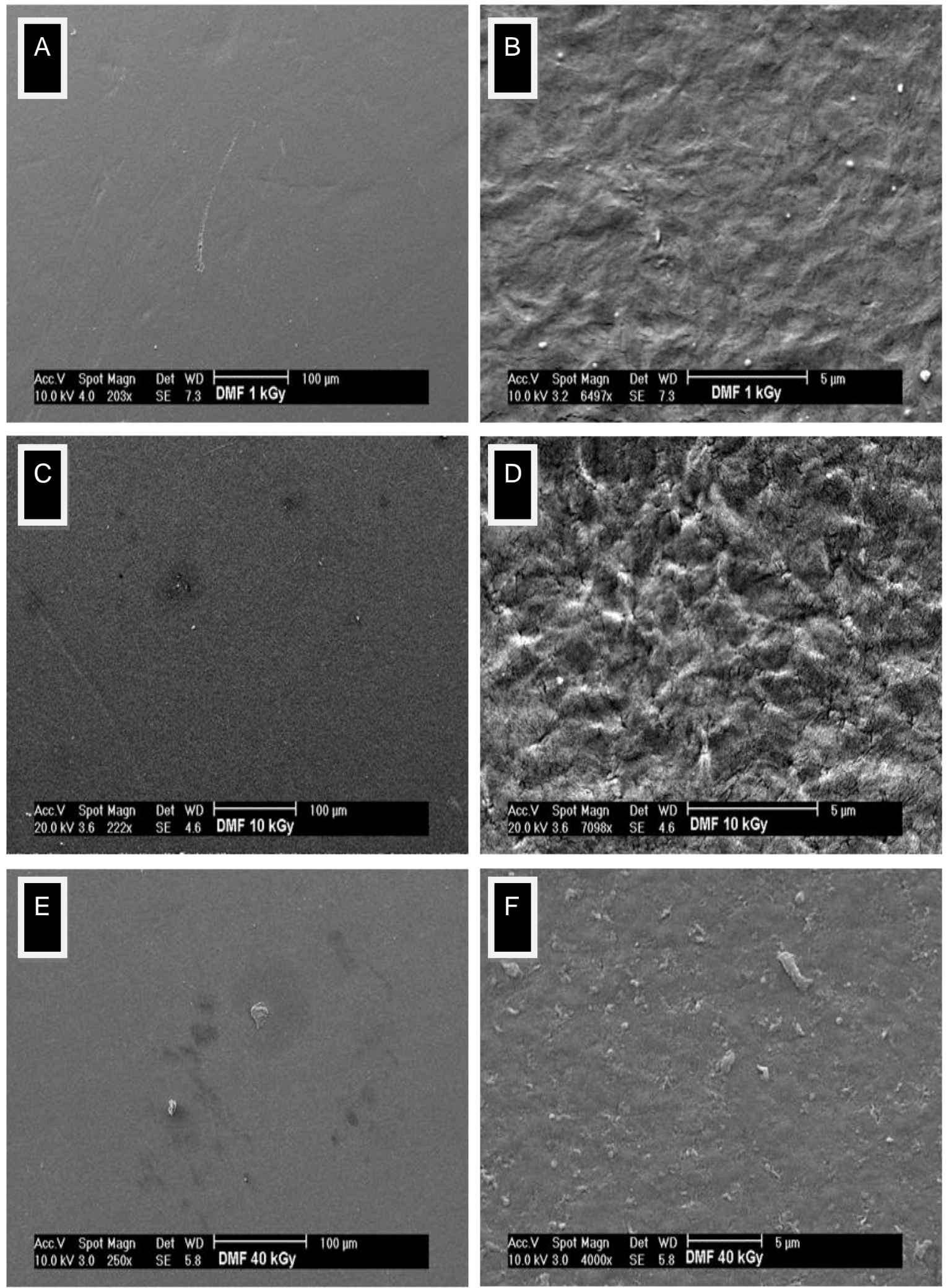

Figura 18 - Micrografias de superfícies de filmes de PVDF enxertado em estireno/DMF em diferentes doses: 1 kGy (A e B); 10 kGy (C e D) e 40 kGy (E e F). 

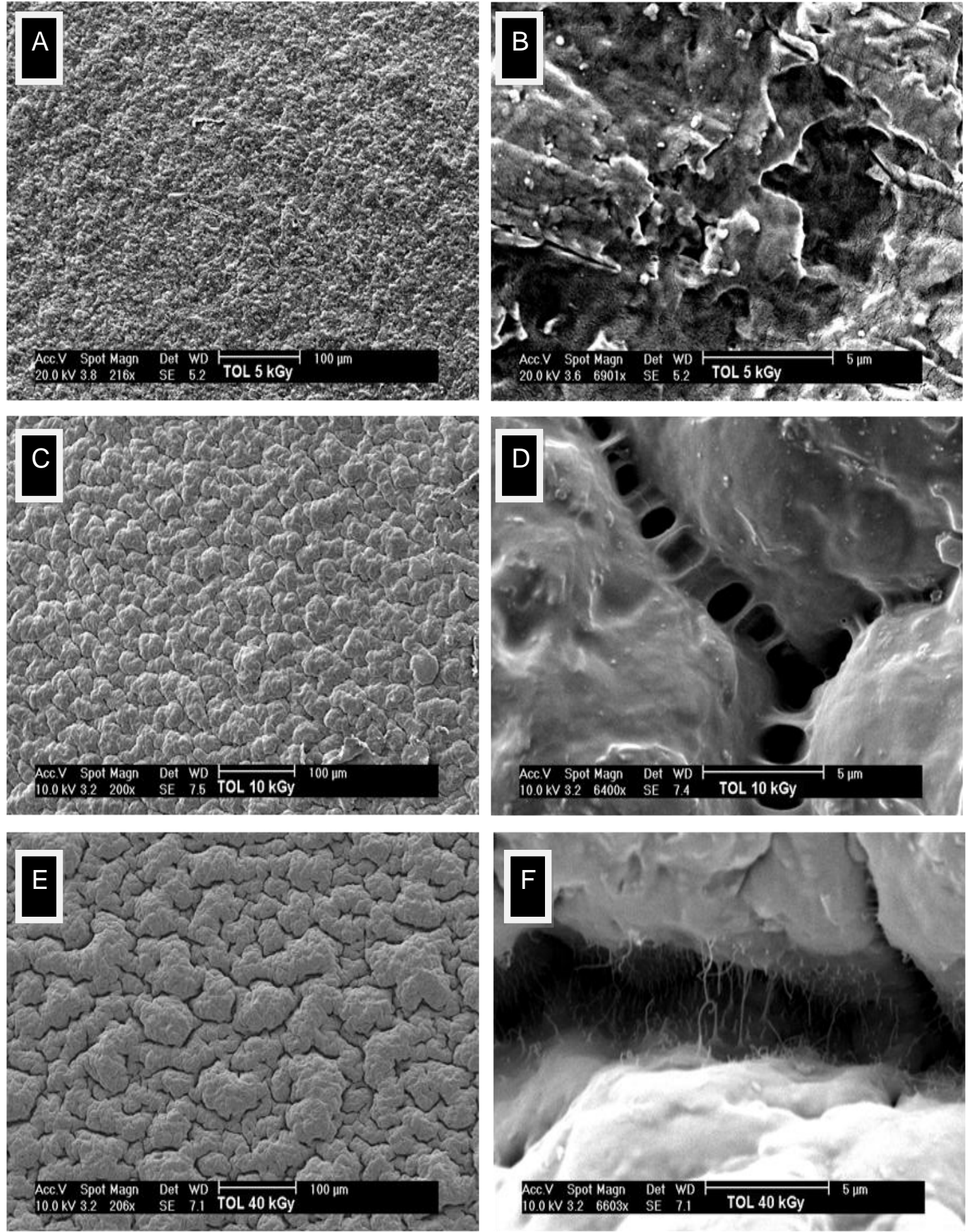

Figura 19 - Micrografias de superfícies de filmes de PVDF enxertado em estireno/tolueno com dose de 5 kGy (A e B), 10 kGy (C e D) e 40 kGy (E e F). 
Contudo, para as enxertias mais altas, da ordem de $90 \%$ obtidas com doses de 80 e 100 kGy, o material resultante apresenta-se bastante frágil, em decorrência da grande quantidade de poliestireno, que é bastante quebradiço. As micrografias superficiais apresentadas na FIG. 20 correspondem ao PVDF enxertado em solução de estireno/DMF com dose de 100 kGy com ampliações de 200 e 4000x (A e B respectivamente), ao passo que na FIG. 21 são apresentas as micrografias superficiais do PVDF enxertado em solução de estireno/tolueno nas mesmas condições utilizadas para a FIG. 20.
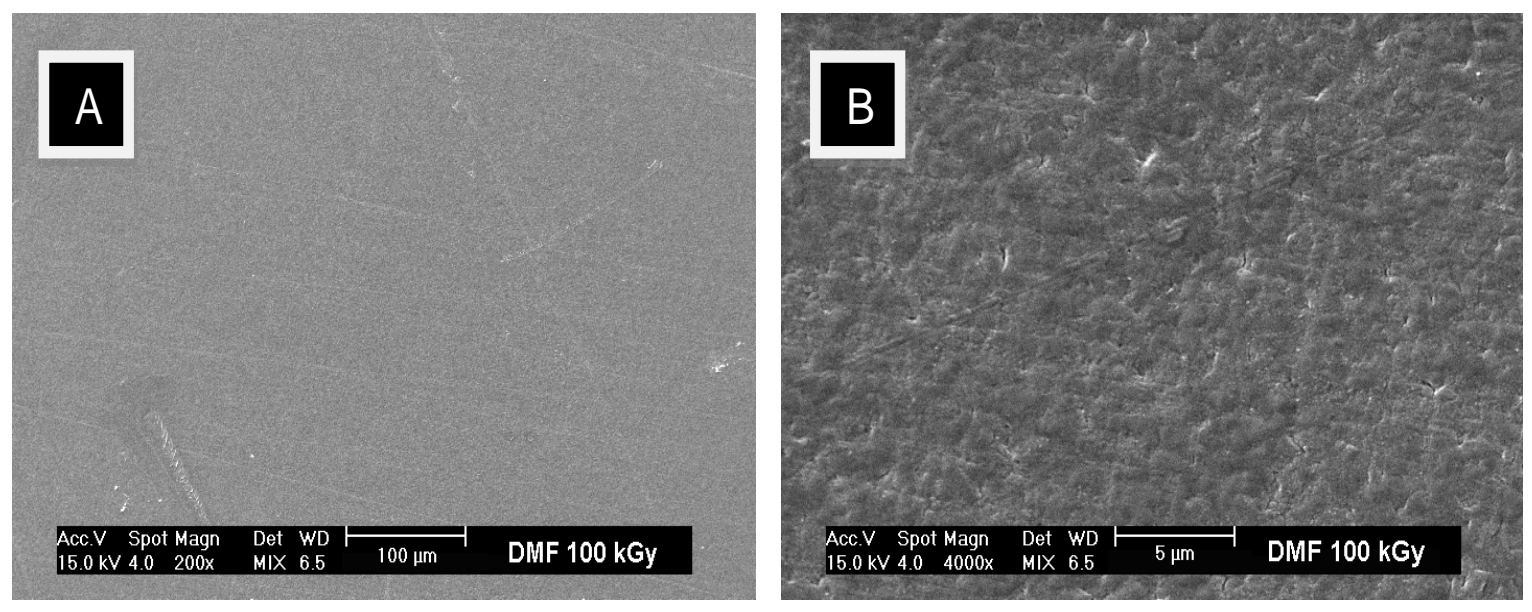

Figura 20 - Micrografias de superfície do filme de PVDF enxertado em DMF/estireno com dose de 100 kGy.
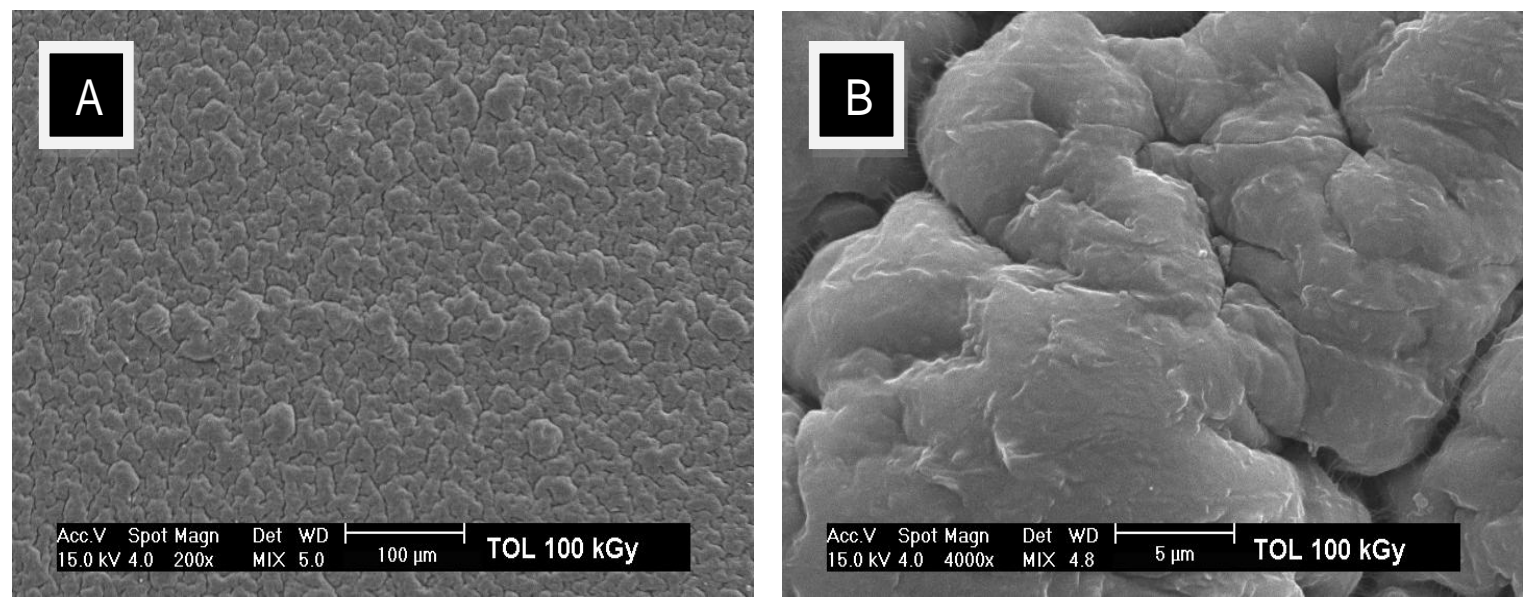

Figura 21 - Micrografias de superfície do filme de PVDF enxertado em tolueno/estireno com dose de $100 \mathrm{kGy}$. 
As morfologias obtidas por ambos os solventes se repetem mesmo para as doses mais elevadas, com a formação de uma camada rugosa e irregular de poliestireno quando o tolueno é usado como solvente ao passo que a DMF favorece a enxertia de maneira homogênea.

Após a sulfonação, os polímeros mais uma vez apresentaram grandes diferenças quando comparamos os solventes utilizados na etapa de enxertia e também quando comparamos a concentração de ácido utilizada na etapa de sulfonação, fato esse visível nas FIG. 22 e 23, que mostram as micrografias das amostras enxertadas em DMF e em tolueno, respectivamente, após a etapa de sulfonação.

Podemos perceber as alterações provocadas pelo ataque ácido nas amostras enxertadas em DMF, que sugerem a formação de poros ou canais, afastados entre si pela inserção dos grupos sulfônicos nos anéis aromáticos, que tenderiam a formar domínios hidrofílicos separados da matriz de PVDF hidrofóbico. Esse fato não foi notado para as amostras irradiadas com 1 e 2,5 kGy sulfonadas com ambas as concentrações de ácido nem para a amostra irradiada com 5 kGy em $2 \%$ de ácido.

Por meio deste resultado podemos inferir que as amostras enxertadas em DMF apresentam maiores quantidades de grupos sulfônicos ligados aos anéis aromáticos do estireno enxertado.

Já as amostras enxertadas em tolueno não parecem apresentar diferenças superficiais após a etapa de sulfonação quando comparamos ao polímero apenas enxertado ou enxertado em DMF, mesmo para concentração mais elevada de ácido, sugerindo uma baixa quantidade de grupos sulfônicos. Este fato sugere um baixo rendimento de sulfonação das amostras enxertadas em tolueno quando comparadas com a DMF, informação obtida mais claramente por meio do cálculo da capacidade de troca iônica (IEC) - item 5.4. 

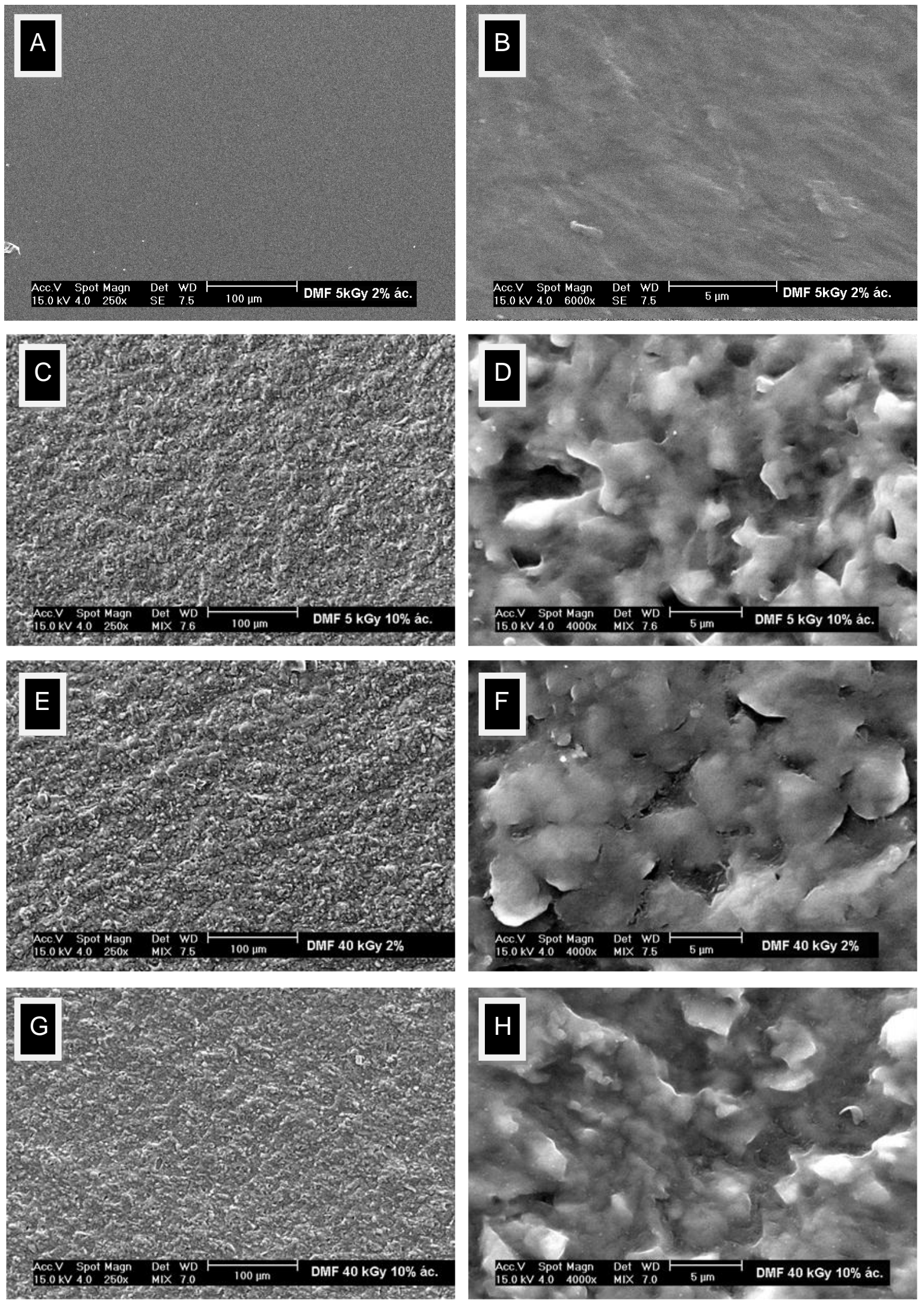

Figura 22 - Micrografias de superfícies de amostras enxertadas em solução contendo DMF e sulfonadas com solução a $2 \%(A, B, E, F)$ e $10 \%(C, D, G, H)$ de ácido clorossulfônico. 

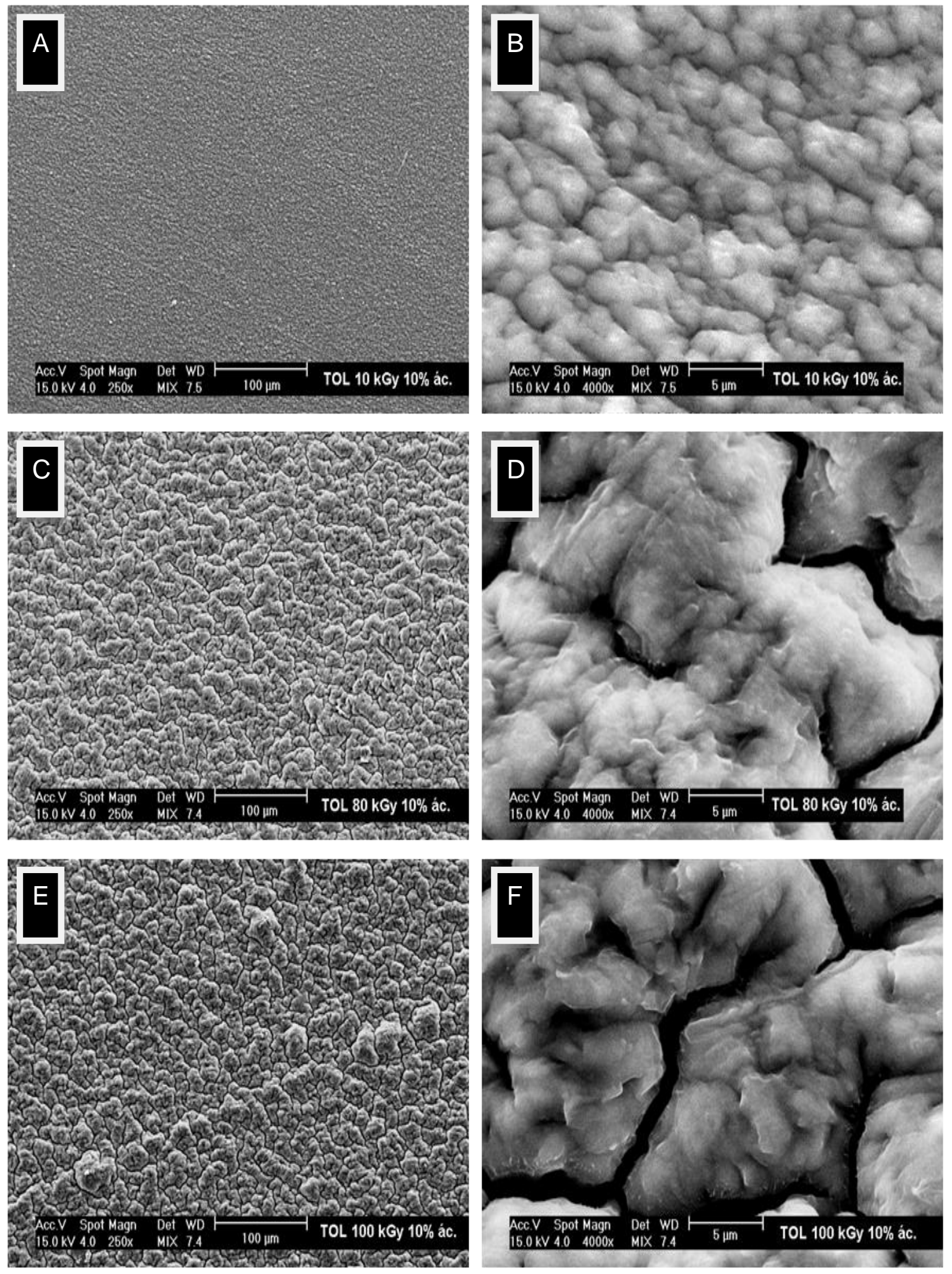

Figura 23 - Micrografias de superfícies das amostras enxertadas em solução contendo tolueno e sulfonadas com solução a $10 \%$ de ácido clorossulfônico. 
Na FIG. 24 são apresentadas as micrografias superficiais das amostras enxertadas em DMF com dose de 100 kGy e sulfonadas em solução a 2 e $10 \%$ de ácido clorossulfônico, respectivamente. Podemos notar certa semelhança na rugosidade superficial. Embora as amostras tenham sido desidratadas antes da obtenção das imagens, é possível perceber a irregularidade superficial provocada pelo ataque ácido e que podem ser os poros ou canais formados pela presença de grupos sulfônicos.
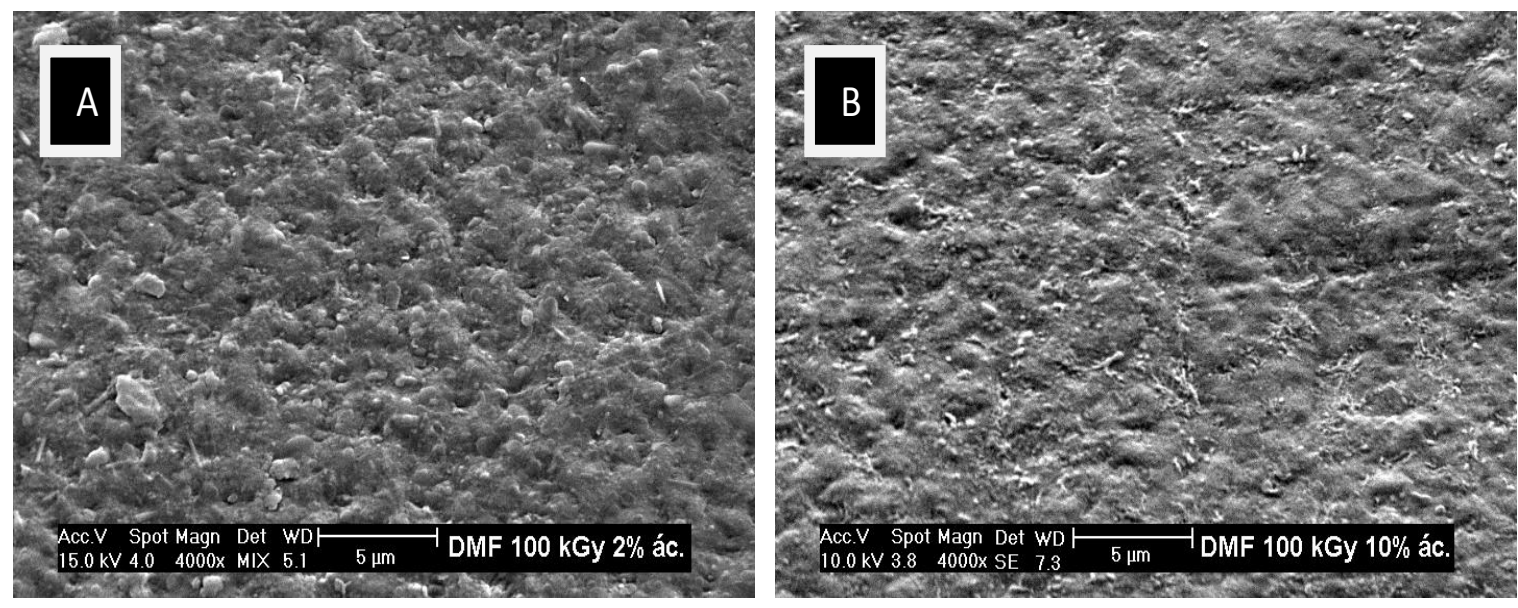

Figura 24 - Micrografias de superfície das amostras enxertadas em DMF com dose de 100 kGy e sulfonadas com solução a 2\% (A) e 10\% (B) de ácido clorossulfônico.

\subsection{Espectroscopia de energia dispersiva (EDS)}

As FIG. 25, 26 e 27 mostram, respectivamente, os espectros de EDS do material prístino, dos enxertados e sulfonados, e na Tabela 1, em seguida, são apresentados os percentuais dos átomos de flúor e de enxofre (quando presente) de cada amostra. Podemos perceber por meio da FIG. 25 os picos referentes ao flúor e ao ouro, tendo este sido utilizado no recobrimento dos filmes para a obtenção das micrografias (MEV) e presente em todos os espectros de EDS. 


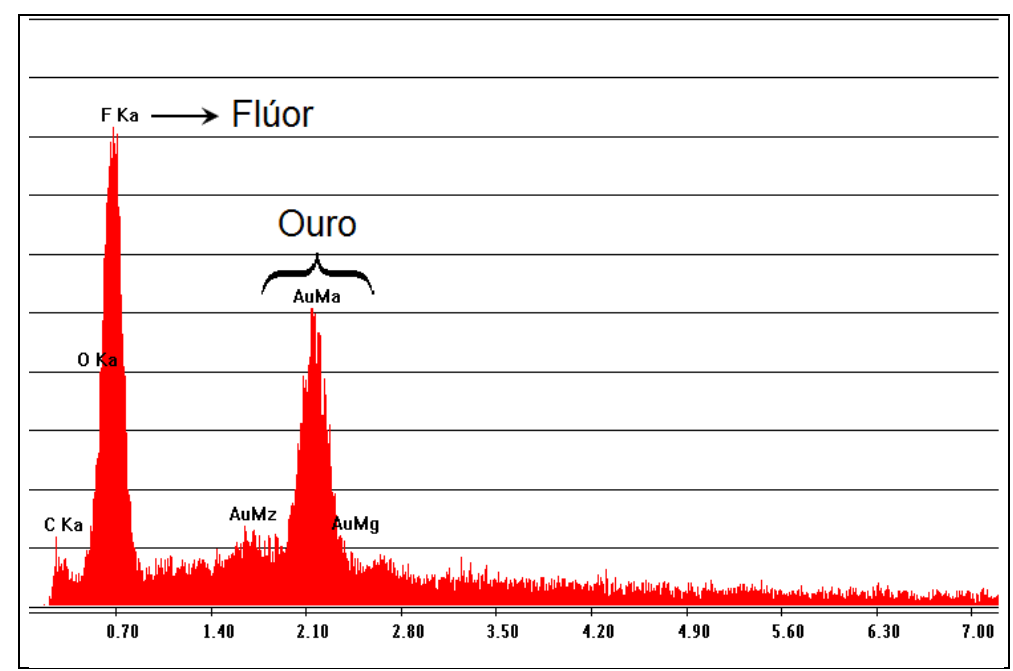

Figura 25 - Espectro de EDS do PVDF prístino.

$\mathrm{Na}$ FIG. 26 são apresentados os espectros de EDS de amostras enxertadas com estireno dissolvido em tolueno e em DMF para uma dose intermediária (40 kGy).

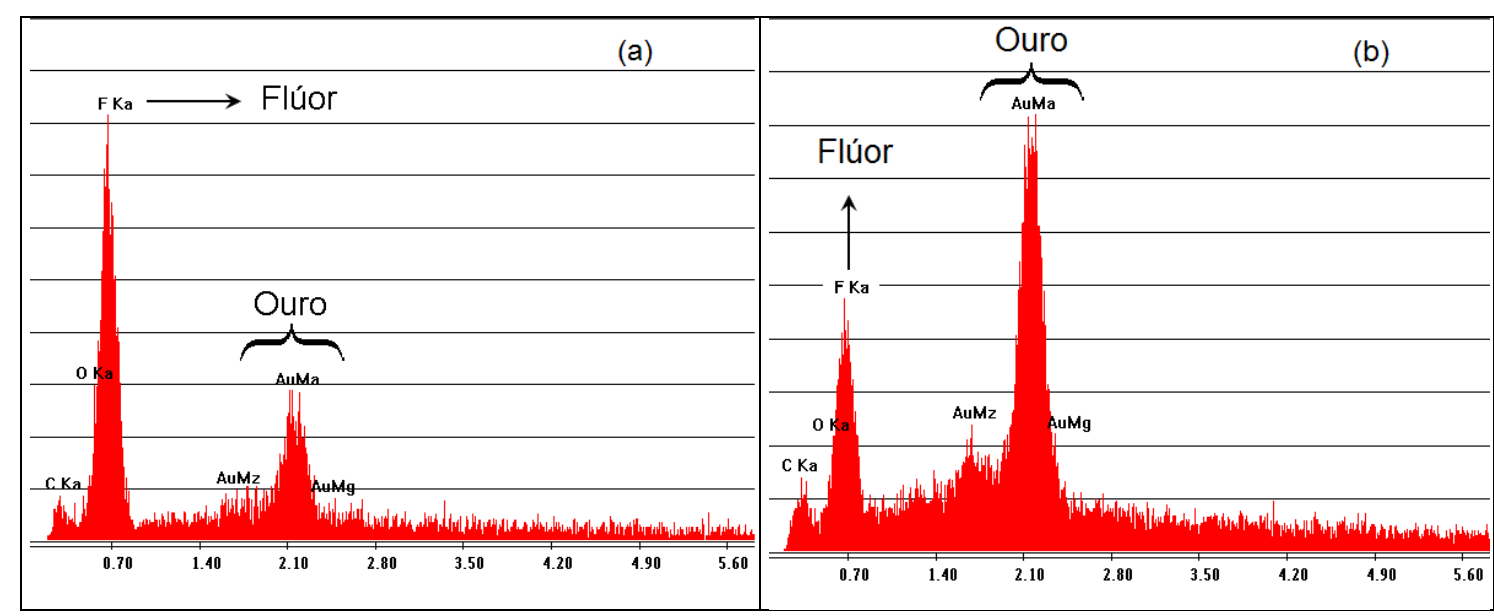

Figura 26 - Espectros de EDS do PVDF enxertado em tolueno (a) e em DMF (b) com dose de 40 kGy.

Já na FIG. 27 são apresentados os espectros de EDS das amostras enxertadas com dose de 40 kGy e posteriormente sulfonadas, respectivamente, com $2 \%$ e $10 \%$ de ácido clorossulfônico: enxertadas em tolueno (a e b) e em DMF (c e d). 


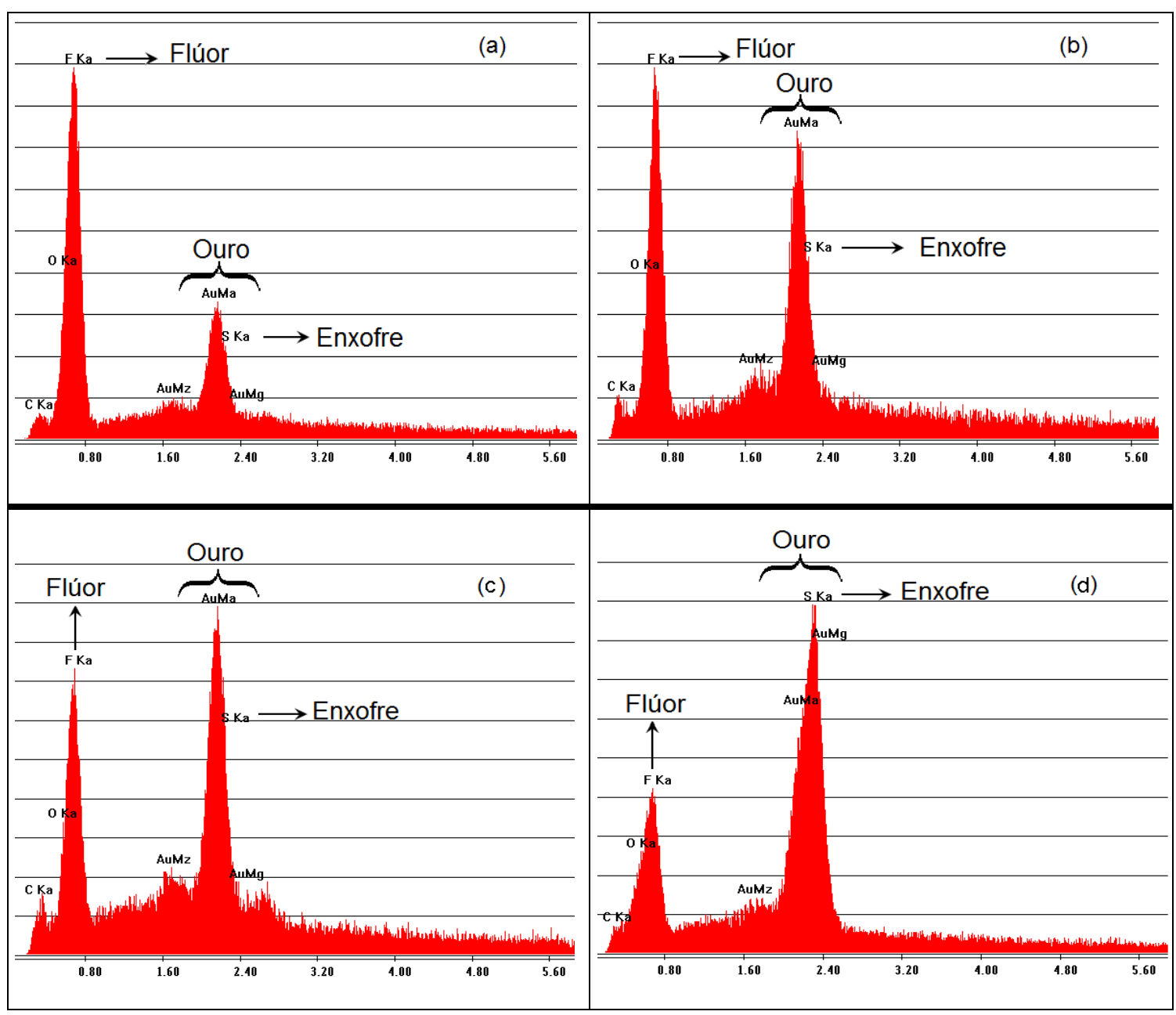

Figura 27 - Espectros de EDS do PVDF enxertado em dose de $40 \mathrm{kGy}$ em tolueno $(a, b)$ e em DMF (c, d) e sulfonadas com 2\% (amostras a e c) e $10 \%$ (amostras b e d) de ác. clorossulfônico.

$\mathrm{Na}$ Tabela 1 são apresentados os valores das quantidades em percentagem de massa (Wt\%) e atômica (At\%) de flúor (F) e de enxofre (S) (quando presente) para os materiais prístino, enxertados e sulfonados. Os demais elementos (carbono, oxigênio e hidrogênio) não estão representados corretamente nos espectros e sua presença não é quantificada na tabela a seguir, pois o limite de detecção do equipamento se restringiu aos elementos com números atômicos maiores ou iguais ao do flúor $(Z=9)$. 
Tabela 1 - Percentuais de átomos presentes em cada material.

\begin{tabular}{c|c|c|c}
\hline Amostra & Elemento & Wt \% & At \% \\
\hline PVDF prístino & $\mathrm{F}$ & 68,7 & 60,55 \\
\hline TOL - 40 kGy ${ }^{\text {a }}$ & $\mathrm{F}$ & 67,68 & 59,27 \\
\hline DMF - 40 kGy ${ }^{\mathbf{b}}$ & $\mathrm{F}$ & 57,67 & 48,11 \\
\hline \multirow{2}{*}{ TOL - 40 kGy - 2\% Ac. Clorossulfônico } & $\mathrm{F}$ & 69,95 & 63,93 \\
\cline { 2 - 4 } & $\mathrm{S}$ & 3,35 & 1,81 \\
\hline \multirow{2}{*}{ TOL - 40 kGy - 10\% Ac. Clorossulfônico } & $\mathrm{F}$ & 59,45 & 52,84 \\
\cline { 2 - 4 } & $\mathrm{S}$ & 6,49 & 3,42 \\
\hline \multirow{2}{*}{ DMF - 40 kGy - 2\% Ac. Clorossulfônico } & $\mathrm{F}$ & 54,30 & 47,81 \\
\cline { 2 - 4 } & $\mathrm{S}$ & 8,16 & 4,26 \\
\hline \multirow{2}{*}{ DMF - 40 kGy - 10\% Ac. Clorossulfônico } & $\mathrm{F}$ & 35,07 & 33,38 \\
\cline { 2 - 4 } & $\mathrm{S}$ & 25,28 & 14,25 \\
\hline
\end{tabular}

a representa a amostra enxertada em solução de estireno/tolueno irradiada com $40 \mathrm{kGy}$

b representa a amostra enxertada em solução de estireno/DMF irradiada com 40 kGy

Com relação às amostras enxertadas, quando comparadas com o polímero prístino, podemos notar a redução da quantidade de flúor que pode ser diretamente relacionada com o aumento da quantidade de hidrocarbonetos, neste caso, provenientes do monômero enxertado. Uma vez que a enxertia alcançada em presença de tolueno foi bastante baixa, os valores são próximos aos do polímero prístino, ao passo que o grau de enxertia obtido em mesma dose, mas com o uso de DMF como solvente foi muito maior, a redução da presença de flúor foi mais acentuada.

Quando comparamos as amostras sulfonadas, é possível observar a diferença na composição das amostras por meio do aumento da quantidade de enxofre com o uso de maior concentração de ácido clorossulfônico e também a variação com relação ao solvente utilizado para enxertia (consequentemente diferentes graus de enxertia). 


\subsection{Capacidade de troca iônica (IEC)}

Na FIG. 28 são apresentados os valores de IEC teóricos e obtidos experimentalmente para amostras enxertadas em tolueno com diferentes doses de irradiação e sulfonadas com soluções de ácido clorossulfônico em concentrações de 2 e 10\% em 1,2-dicloroetano. Já na FIG. 29 são apresentadas as mesmas informações para as amostras que foram enxertadas em DMF.

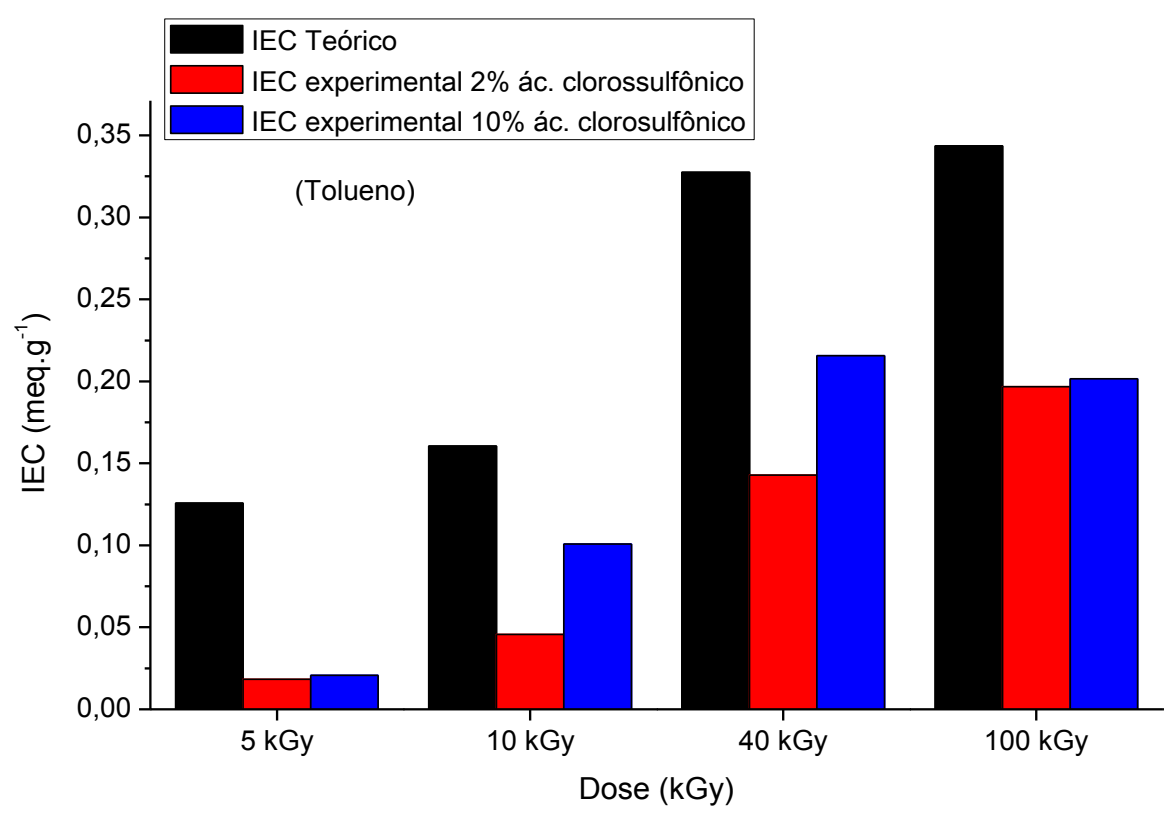

Figura 28 - IEC das amostras enxertadas em solução com tolueno.

Há um claro aumento do IEC com o aumento da concentração do ácido, o que pode ser explicado pela maior disponibilidade de grupos sulfônicos ao redor dos enxertos. Também é possível notar que para o tolueno, os IECs obtidos são bastante baixos, sugerindo que os baixos graus de enxertia, bem como sua superficialidade, limitam drasticamente a capacidade de troca iônica. 


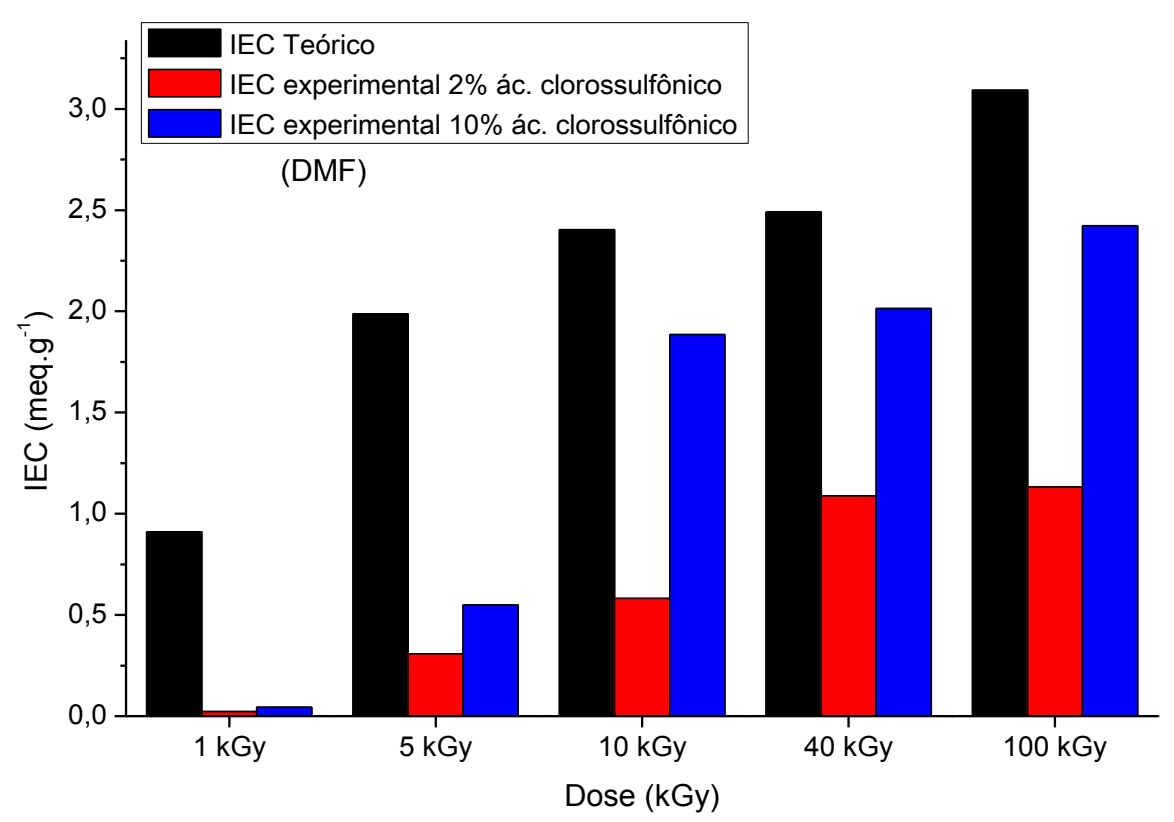

Figura 29 - IEC das amostras enxertadas em solução com DMF.

Para os materiais enxertados em DMF é possível obter IECs superiores aos obtidos em tolueno, mesmo para doses inferiores a 5 kGy. Entretanto, quando comparamos estes resultados com o que pode ser observado por meio das micrografias, os materiais que apresentaram formação de poros apresentam IECs mais elevados. É importante salientar que as capacidades de troca iônica obtidas com as amostras enxertadas em DMF, principalmente para as doses maiores ou iguais a 10 kGy, igualam ou superam o IEC do Nafion, que é em torno de 1 meq. $g^{-1}[9]$.

Entretanto, as amostras enxertadas em DMF com doses mais elevadas, de 80 e 100 kGy, apresentam-se bastante degradadas por apresentarem grande quantidade de poliestireno e ficam bastante frágeis, principalmente após a etapa de sulfonação, dificultando ou até mesmo impedindo sua manipulação.

Por meio dos resultados aqui apresentados, também podemos notar que nenhuma amostra atingiu ou superou os valores teóricos, o que leva a crer que não houve $100 \%$ de sulfonação, ou seja, apenas uma parte dos anéis sofreram sulfonação, embora as amostras com maiores graus de enxertia e sulfonadas com solução mais concentrada tenham se aproximado de tais valores. 
Podemos dizer que a etapa de sulfonação é um ponto-chave na obtenção de materiais com capacidades de troca iônica, pois, por meio da alteração de parâmetros como concentração de ácido, tempo de reação e temperatura do meio reacional, podemos obter diferentes resultados de IEC para uma amostra enxertada [10, 14,60$]$.

\subsection{Calorimetria exploratória diferencial (DSC)}

Nas FIG. 30 e 31 são apresentadas as curvas de cristalização obtidas por calorimetria exploratória diferencial das amostras de PVDF enxertadas em solução contendo DMF e tolueno, respectivamente:

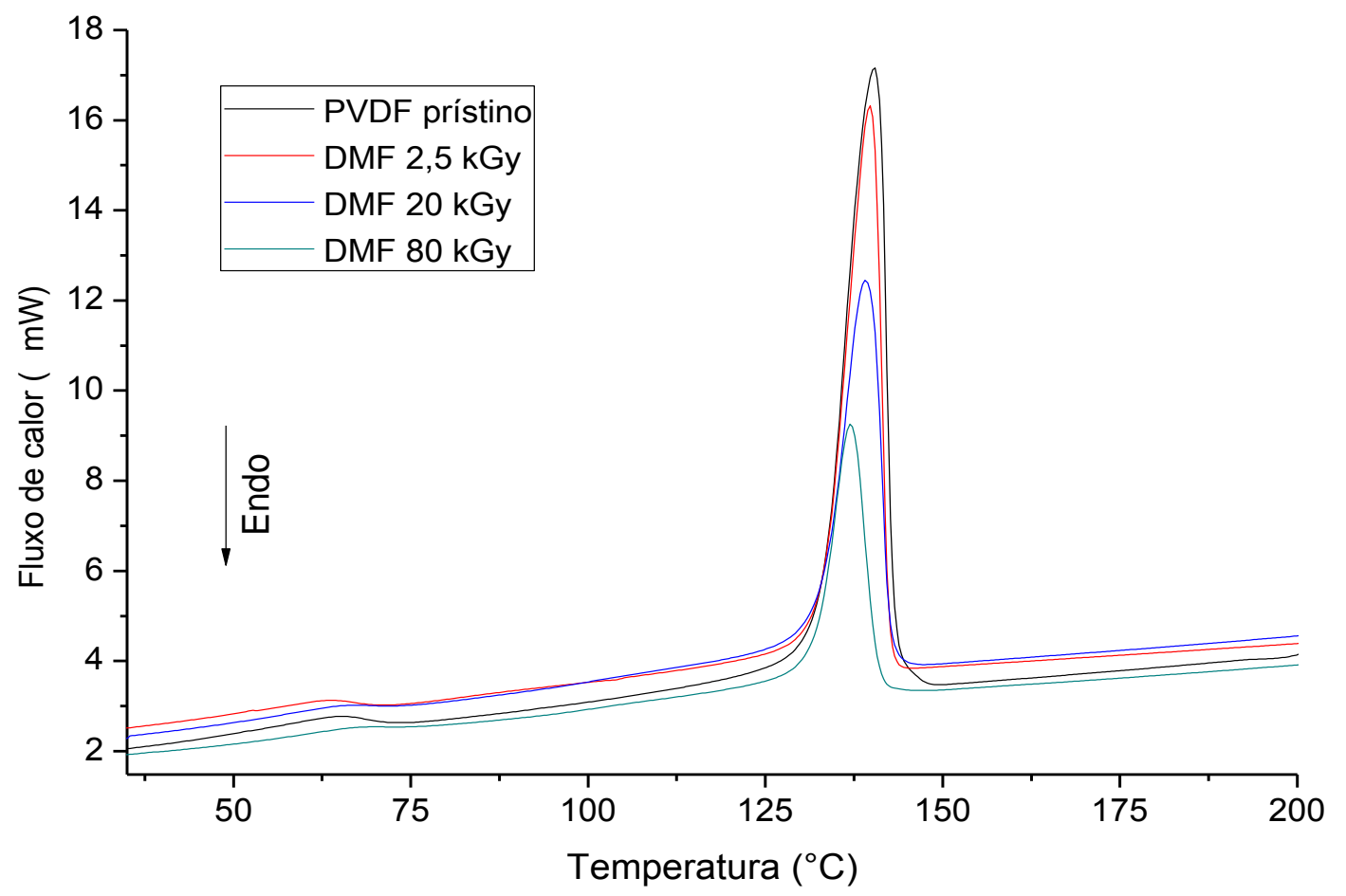

Figura 30 - Curvas de DSC da cristalização de amostras prístina e enxertadas em DMF. 


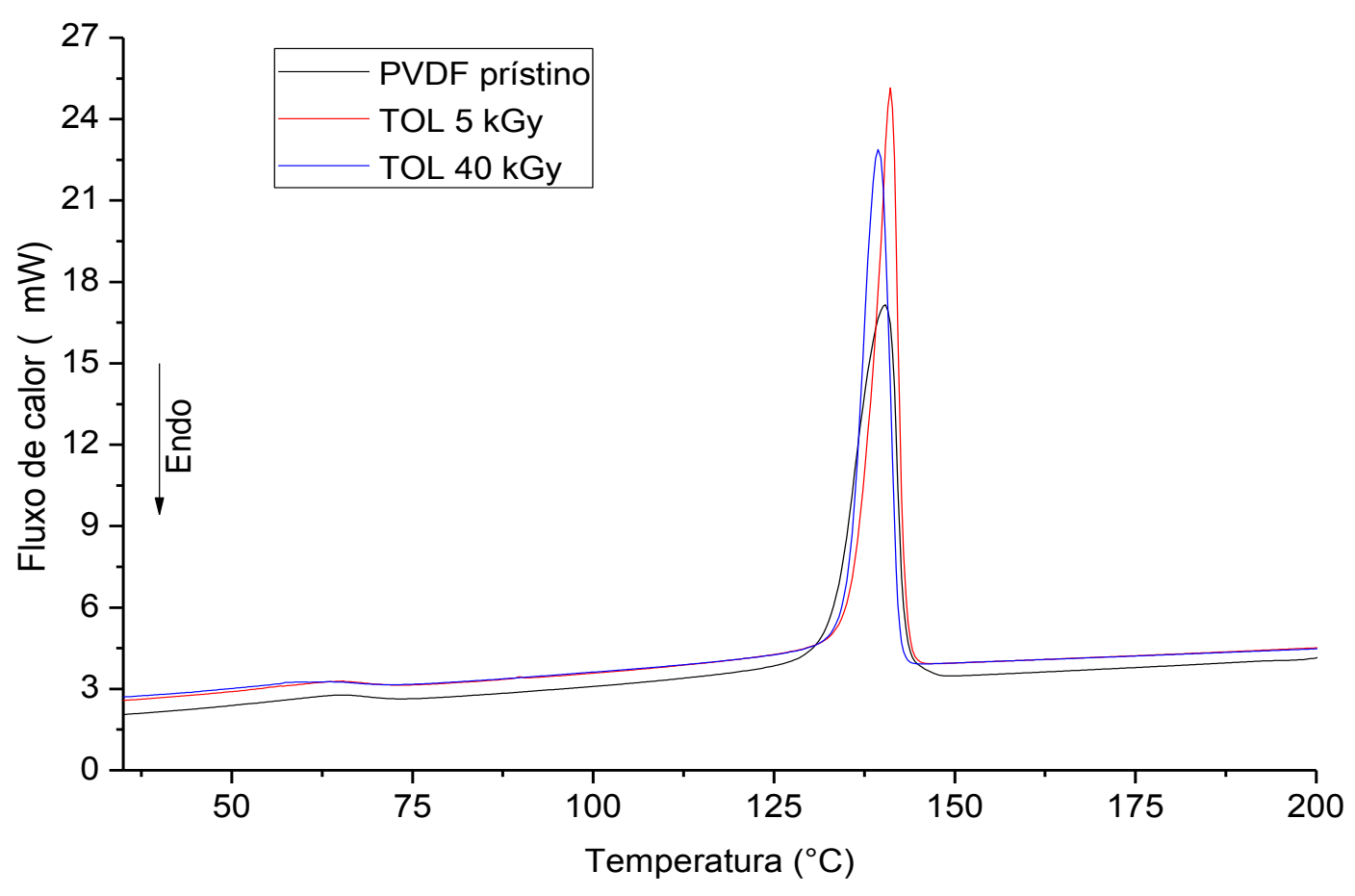

Figura 31 - Curvas de DSC da cristalização das amostras prístina e enxertadas em tolueno.

Podemos notar que para as amostras enxertadas nas soluções com DMF como solvente, com o aumento da enxertia, há diminuição no pico de cristalização quando comparado ao do polímero prístino. Isso pode ser atribuído à maior distância entre os domínios cristalinos do PVDF causada pela maior quantidade de poliestireno no material.

No caso do tolueno, o comportamento térmico é muito próximo ao do polímero prístino, o que mais uma vez evidencia a baixa enxertia e sua superficialidade (como demonstrado por meio das micrografias); o baixo percentual de poliestireno presente praticamente não altera o comportamento da massa polimérica de PVDF.

Na FIG. 32 estão apresentadas as curvas calorimétricas do polímero prístino e enxertado em DMF e em tolueno para uma mesma dose de 10 kGy. 


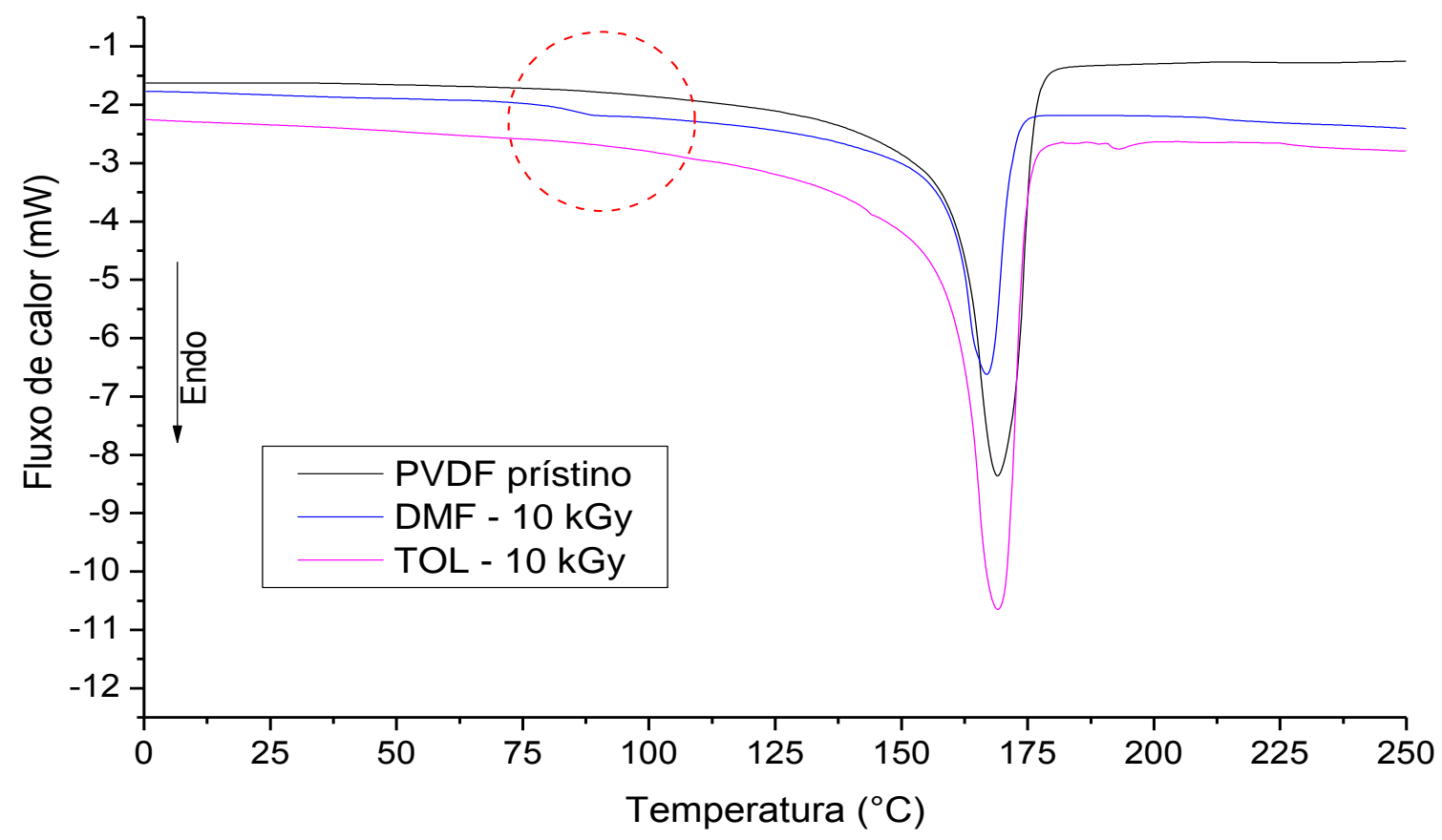

Figura 32 - Curvas de DSC do PVDF prístino e enxertadas em DMF e em tolueno em 10 kGy.

Para o polímero enxertado em DMF há o aparecimento de uma nova região endotérmica por volta de $80 \stackrel{\circ}{ } \mathrm{C}$, explicado pela crescente presença de poliestireno na massa polimérica, já que o poliestireno apresenta ponto de transição vítrea entre 75 e $100^{\circ} \mathrm{C}$ [41] e como visto na FIG. 33, curva obtida do poliestireno formado por aquecimento, como descrito anteriormente.

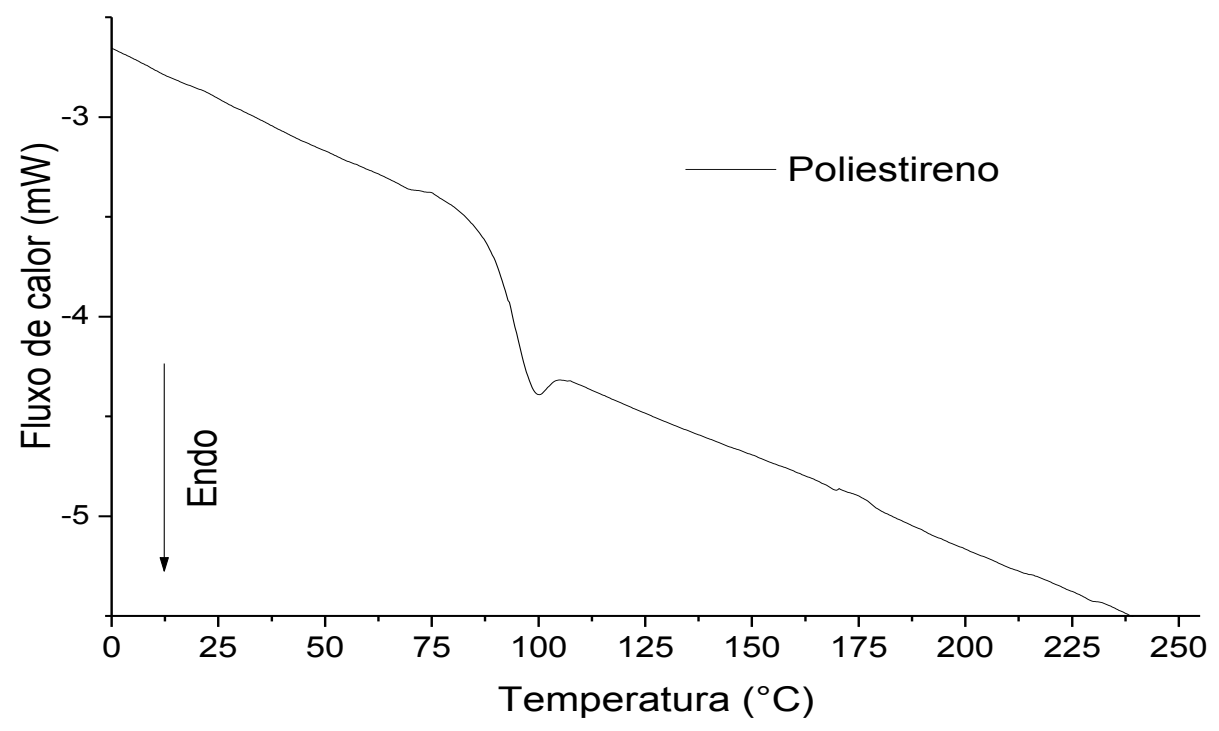

Figura 33 - Curva de DSC do poliestireno. 
As curvas de DSC do PVDF prístino e de amostras enxertadas para duas doses diferentes - 2,5 e 80 kGy para as enxertadas em DMF e 5 e 80 kGy para as enxertadas em tolueno - podem ser vistas com ampliação na região entre 40 e $120^{\circ} \mathrm{C}$ na FIG. 34, na qual é possível perceber que, nas menores doses, as amostras enxertadas em DMF já apresenta o referido evento característico do PS, ficando mais acentuado com o aumento da enxertia. Para as amostras enxertadas em tolueno esse evento não é evidente em nenhuma das doses, uma vez que o grau de enxertia é muito baixo, embora seja possível notar um evento bastante suave na amostra irradiada com 80 kGy na mesma região, o qual pode ser atribuído ao PS.

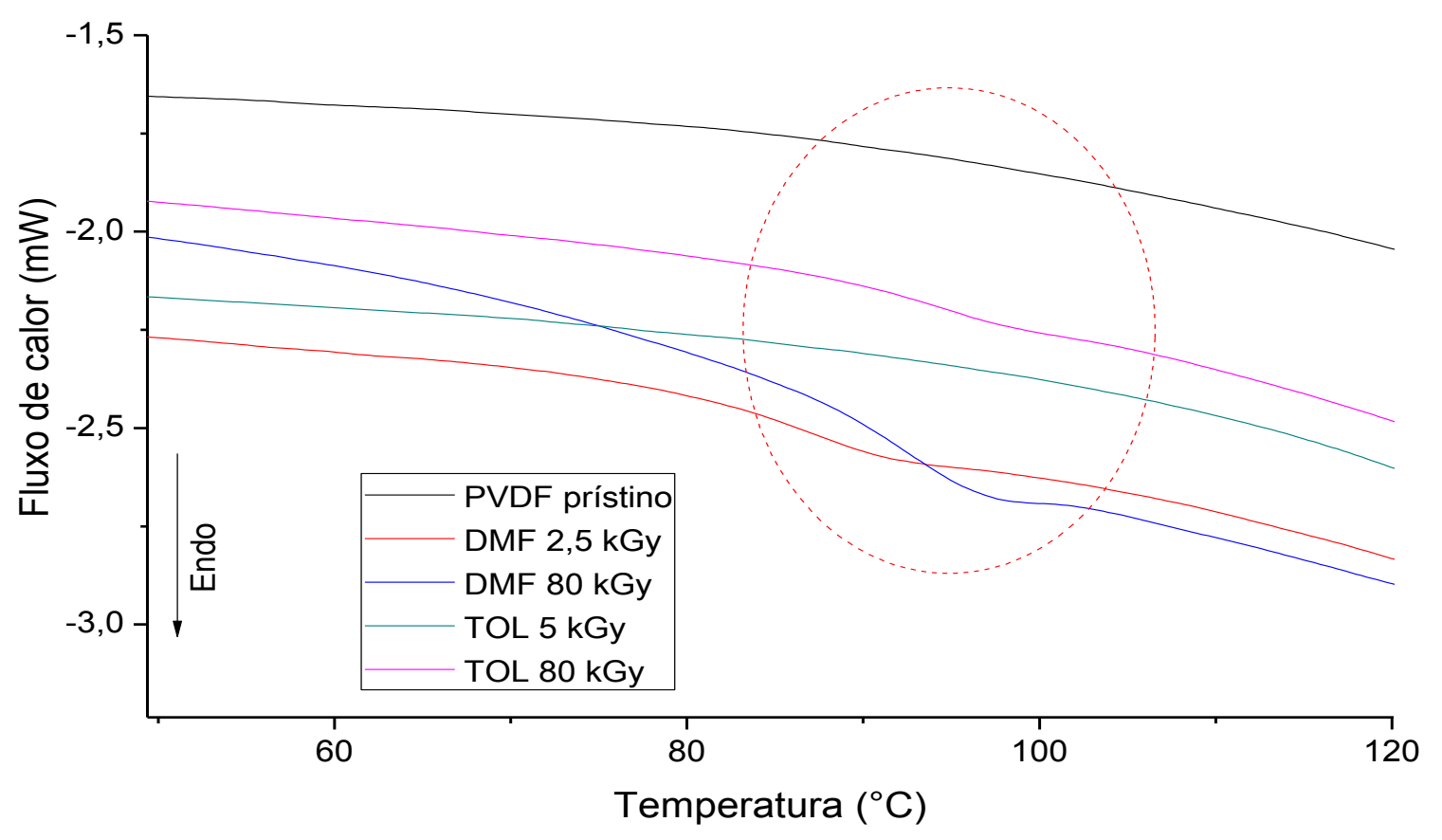

Figura 34 - Curvas de DSC das amostras enxertadas em DMF e em tolueno com diferentes doses de irradiação.

Após a sulfonação, podemos notar uma maior alteração no comportamento térmico das amostras. Nas FIG. 35 e 36 apresentam-se as curvas de DSC dos materiais após a sulfonação com 2 e com 10\% de ácido clorossulfônico, depois de enxertadas em DMF e em tolueno, respectivamente. 


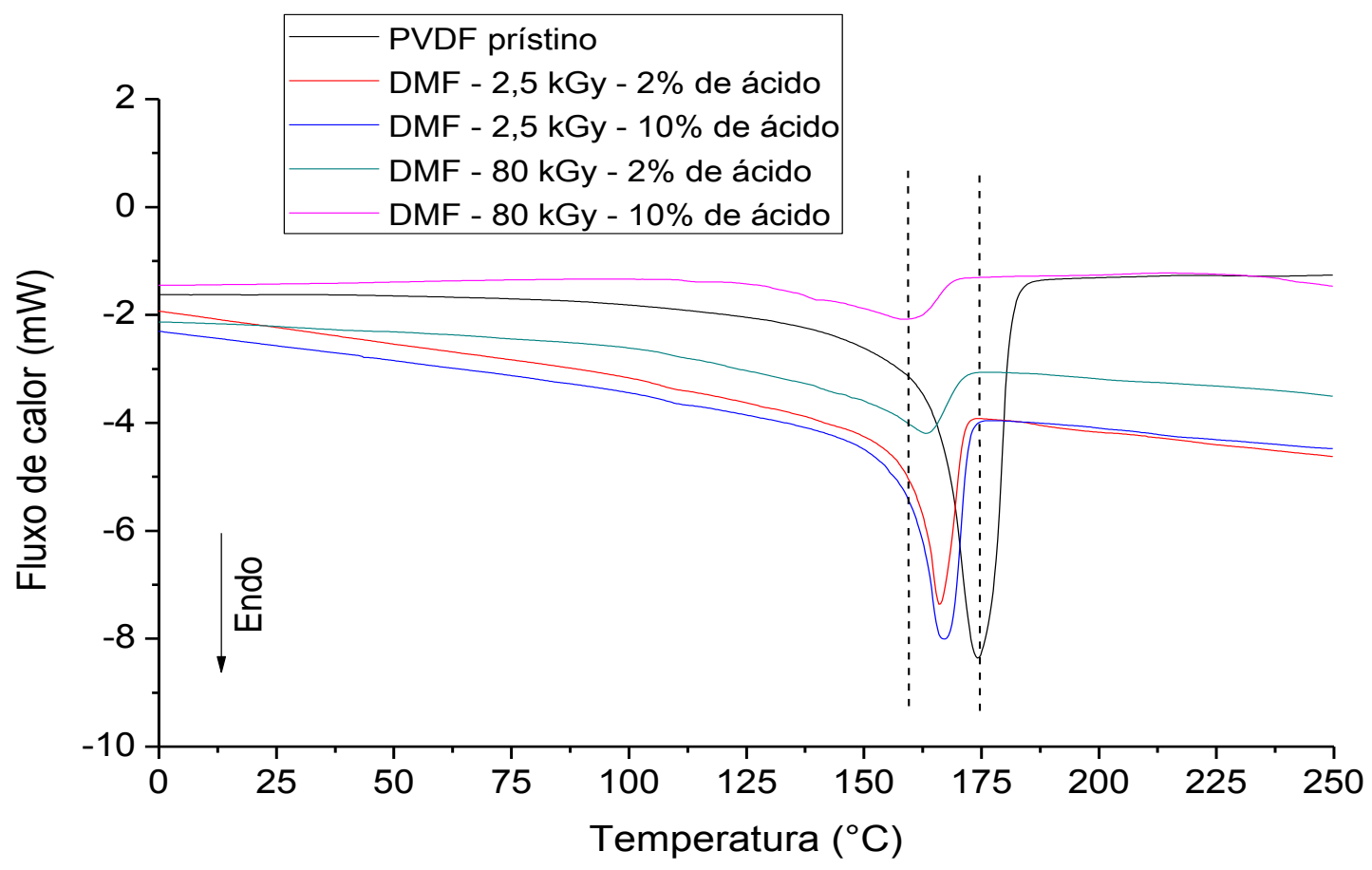

Figura 35 - Curvas de DSC das amostras enxertadas em DMF e sulfonadas a 2\% e 10\%.

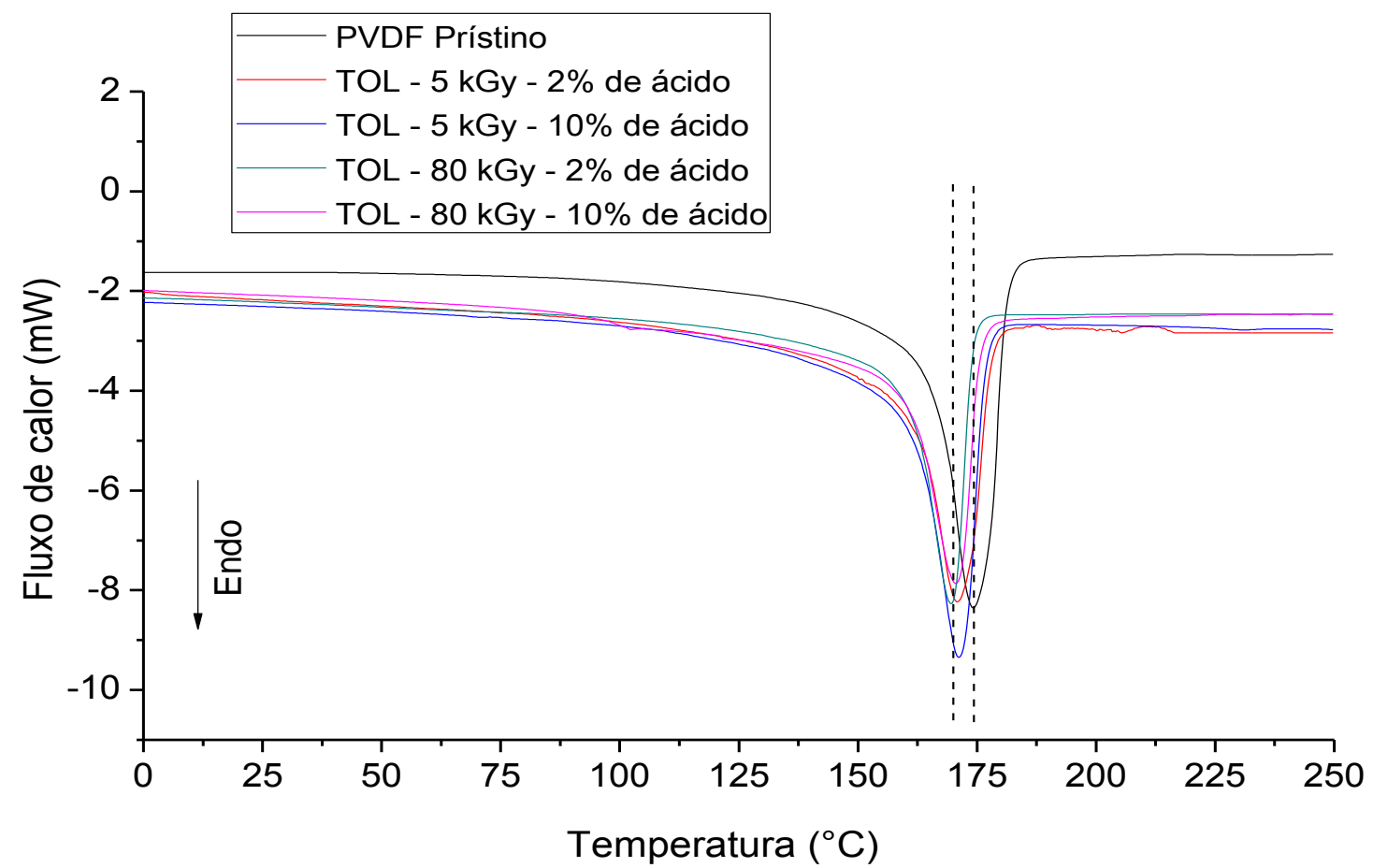

Figura 36 - Curvas de DSC das amostras enxertadas em tolueno e sulfonadas a $2 \%$ e $10 \%$. 
As amostras enxertadas em DMF e sulfonadas apresentam redução do pico de fusão, associado à redução da cristalinidade e essa redução está diretamente relacionada com o aumento do IEC. Já as amostras enxertadas em tolueno praticamente não diferem da amostra prístina, por apresentarem baixo valor de IEC e consequentemente pouca influência no comportamento térmico das amostras como um todo. As diferenças nas temperaturas dos picos de fusão das amostras enxertadas em DMF chagam a ser pouco maiores que $16^{\circ} \mathrm{C}$, enquanto que as das enxertadas em tolueno não chegam a $5^{\circ} \mathrm{C}$.

Fica também evidente o aumento da diferença com o aumento da quantidade de grupos sulfônicos. Nesse aspecto, a sulfonação parece exercer papel mais determinante nas propriedades do polímero do que a enxertia apenas. Os grupos sulfônicos parecem atuar como "plastificantes", impedindo que o PVDF da matriz cristalize, mas ainda é possível perceber uma pequena porção cristalina nas amostras com maiores enxertias e maiores IECs. Nas FIG. 37 e 38 a seguir estão representados os percentuais de cristalinidade das amostras prístinas $(0$ kGy) e enxertadas em tolueno e em DMF sob diferentes doses de irradiação.

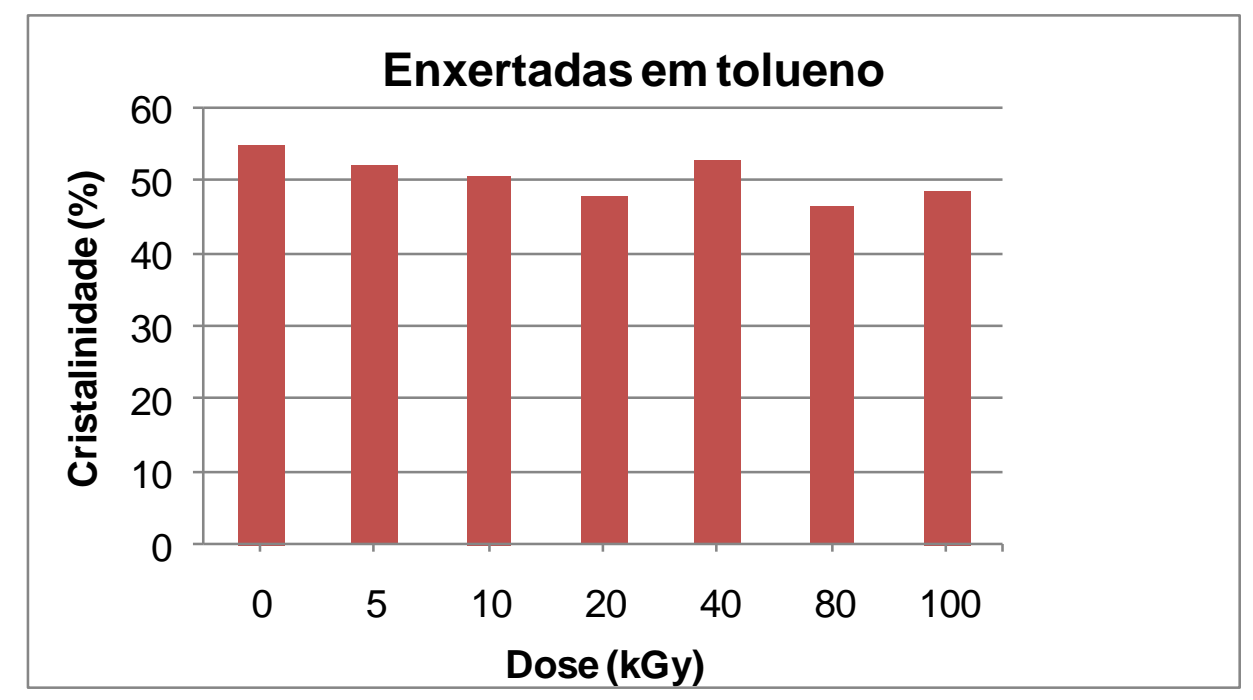

Figura 37 - Cristalinidades das amostras enxertadas em tolueno em função da dose de irradiação. 


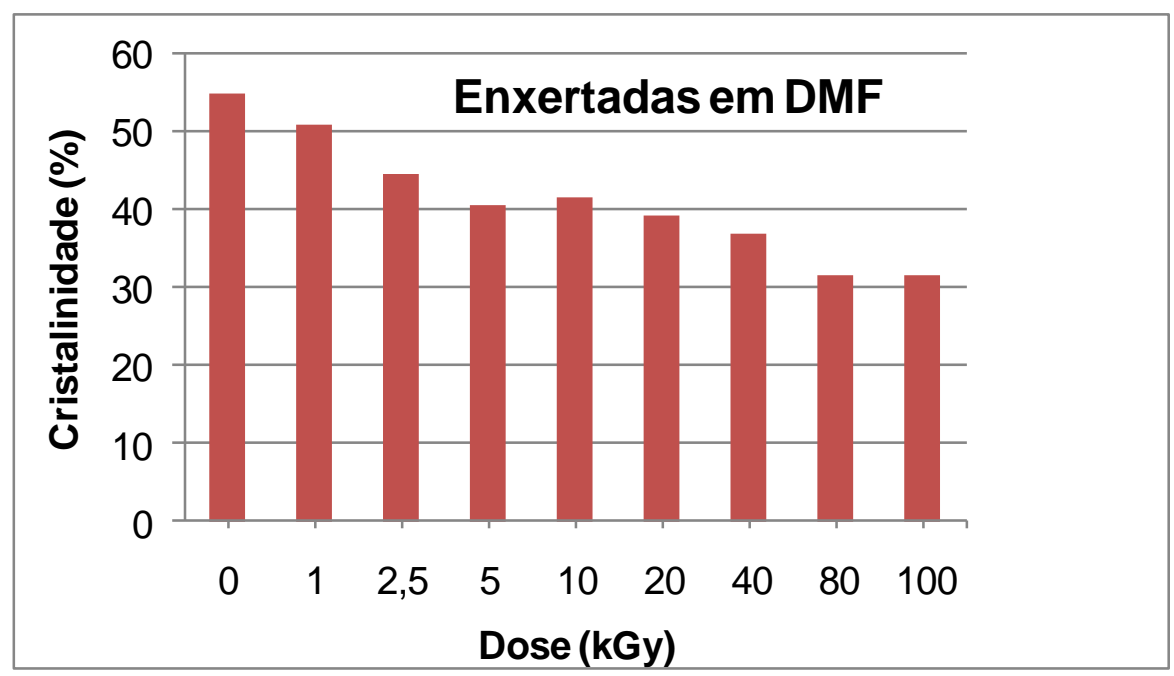

Figura 38 - Cristalinidades das amostras enxertadas em DMF em função da dose de irradiação.

Podemos notar uma redução praticamente linear da cristalinidade proporcional ao aumento da enxertia para as amostras enxertadas em DMF, ao passo que no tolueno as amostras praticamente não diferem do polímero prístino em cristalinidade. Já nas FIG. 39 e 40 são apresentadas as cristalinidades das amostras sulfonadas em função da dose de irradiação e da concentração de ácido clorossulfônico.

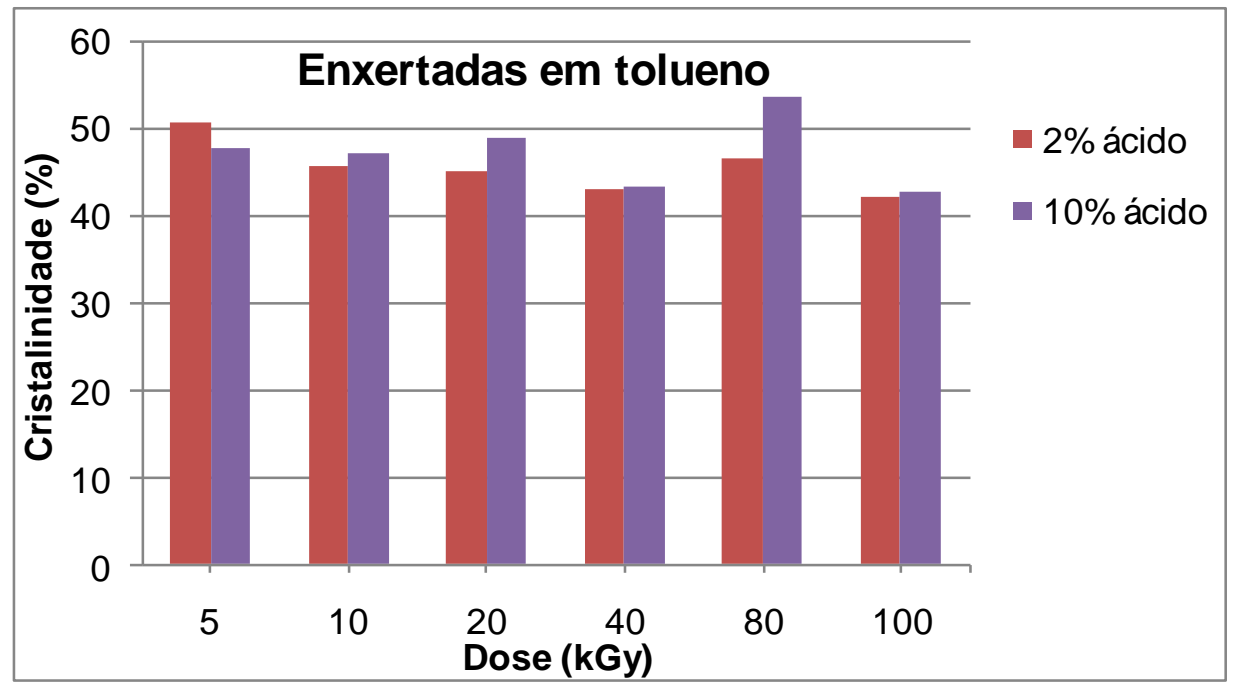

Figura 39 - Cristalinidades das amostras enxertadas em tolueno e sulfonadas, em função da dose de irradiação e concentração de ácido clorossulfônico. 


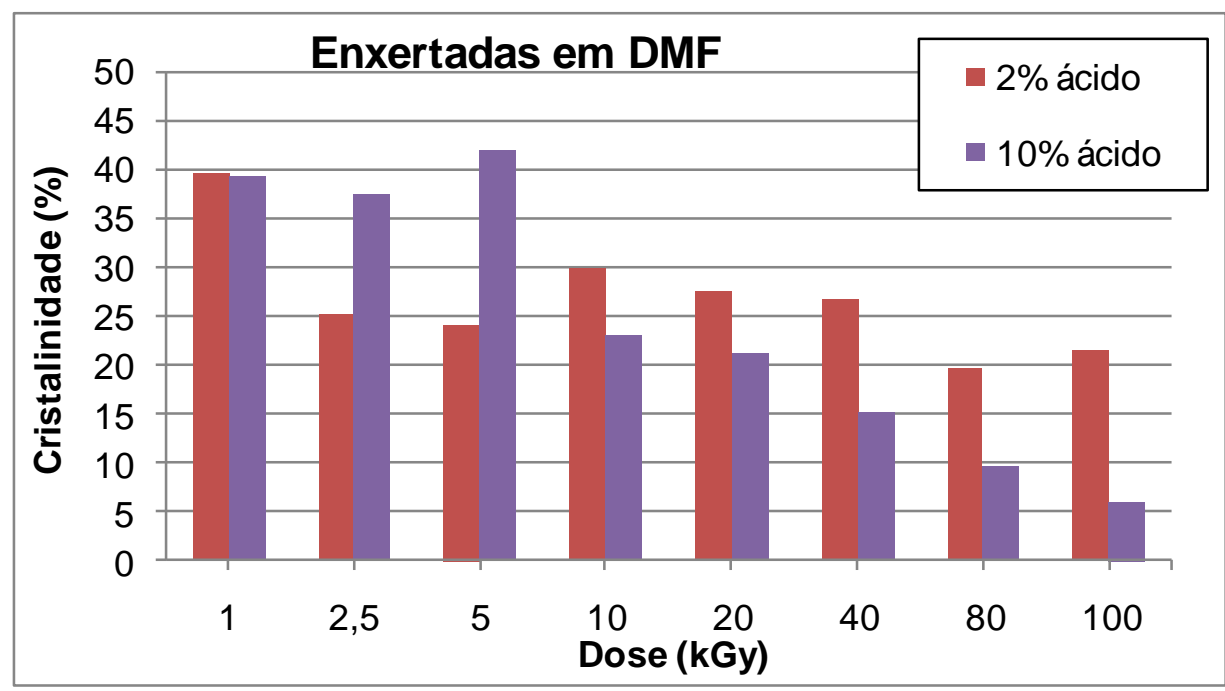

Figura 40 - Cristalinidades das amostras enxertadas em DMF e sulfonadas, em função da dose de irradiação e concentração de ácido clorossulfônico.

As amostras enxertadas em tolueno não apresentam grandes alterações em relação ao polímero prístino, mesmo com altas doses de irradiação, e o mesmo se repete quando o material passou por sulfonação. Isso se deve à baixa quantidade de estireno presente nas amostras e à baixa presença de grupos sulfônicos, fazendo com que as propriedades da matriz polimérica sejam predominantes. A redução de cristalinidade das amostras enxertadas em DMF tanto após a enxertia quanto após a sulfonação parece ser responsável pela fragilização dos materiais mencionada anteriormente.

Cabe ressaltar, entretanto, que os resultados referentes às cristalinidades dizem respeito às amostras como um todo, não sendo considerada apenas a massa das amostras referentes ao PVDF. Considerando-se isso, podemos dizer que o PVDF presente nas amostras enxertadas em DMF parece manter parte de sua cristalinidade original, o que ainda manteria consideráveis propriedades mecânicas mesmo após as modificações realizadas. 


\subsection{Termogravimetria (TG/DTG)}

Na FIG. 41 são apresentadas as curvas termogravimétricas (TG e DTG) do PVDF prístino em atmosfera inerte $\left(\mathrm{N}_{2}\right)$ e oxidativa $\left(\mathrm{O}_{2}\right)$.

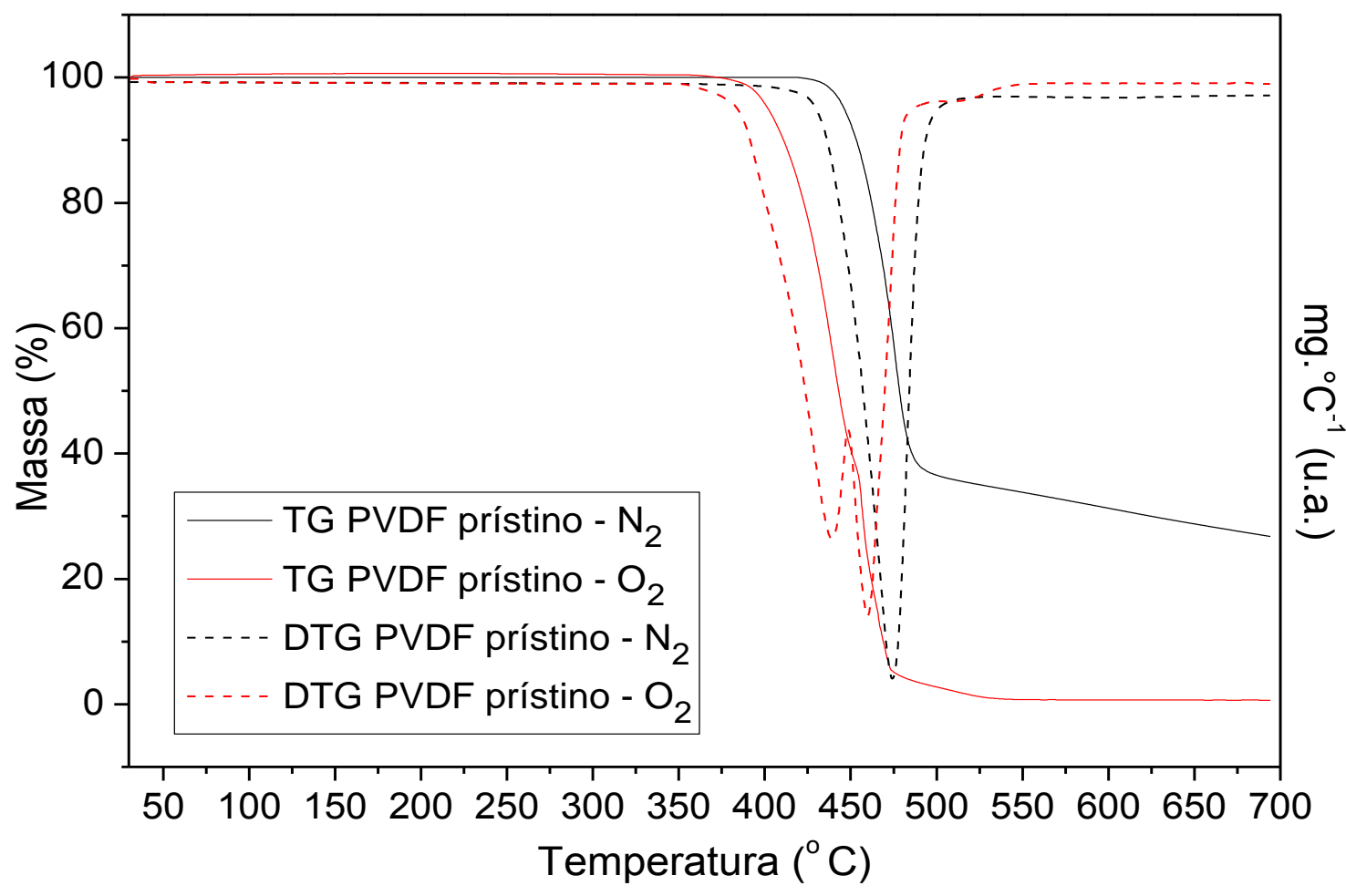

Figura 41 - Curvas de TG e DTG do PVDF prístino em atmosfera de nitrogênio e de oxigênio.

Podemos perceber a diferença quando da utilização de atmosfera inerte em relação à atmosfera oxidativa. Nesta há decomposição em duas etapas e com resíduo praticamente nulo, ao passo que naquela (inerte) a decomposição se dá numa única etapa, mas com a formação de resíduo da ordem de $40 \%$, resíduo este que se decompõe contínua e lentamente após $500^{\circ} \mathrm{C}$.

Em 1987, Gafurov e Yakubov [95] já estudavam a estabilidade térmica de diferentes polímeros fluorados, e descreveram que o PVDF sofre degradação em etapas. Essas etapas estariam ligadas à quebra das ligações de carbonohidrogênio, liberação de fluoreto de hidrogênio (HF) e outros compostos menores e, em seguida, a formação de duplas ligações (insaturações) nas cadeias restantes e a formação de reticulações nessa massa resultante, levando a uma 
diminuição da taxa de decomposição, caracterizada por uma segunda etapa de decomposição.

Essa massa reticulada parece existir em maior grau quando da utilização do nitrogênio durante a termogravimetria. Sem o oxigênio para atacar a matriz, há liberação de compostos hidrogenados e pequenas moléculas fluoradas resultantes da degradação térmica da matriz, restando cerca de $40 \%$ de resíduo constituído por essa massa reticulada e que é lentamente degradada por apresentar alta estabilidade térmica. Quando a atmosfera utilizada durante a termogravimetria é o oxigênio, um comportamento diferente é observado. O resíduo passa a ser praticamente nulo e dois eventos distintos se fazem notáveis. O primeiro associado à primeira degradação das cadeias principais e o segundo associado à degradação da massa reticulada [95].

As curvas termogravimétricas do poliestireno (PS) obtidas em atmosferas de nitrogênio e de oxigênio são apresentadas na FIG. 42.

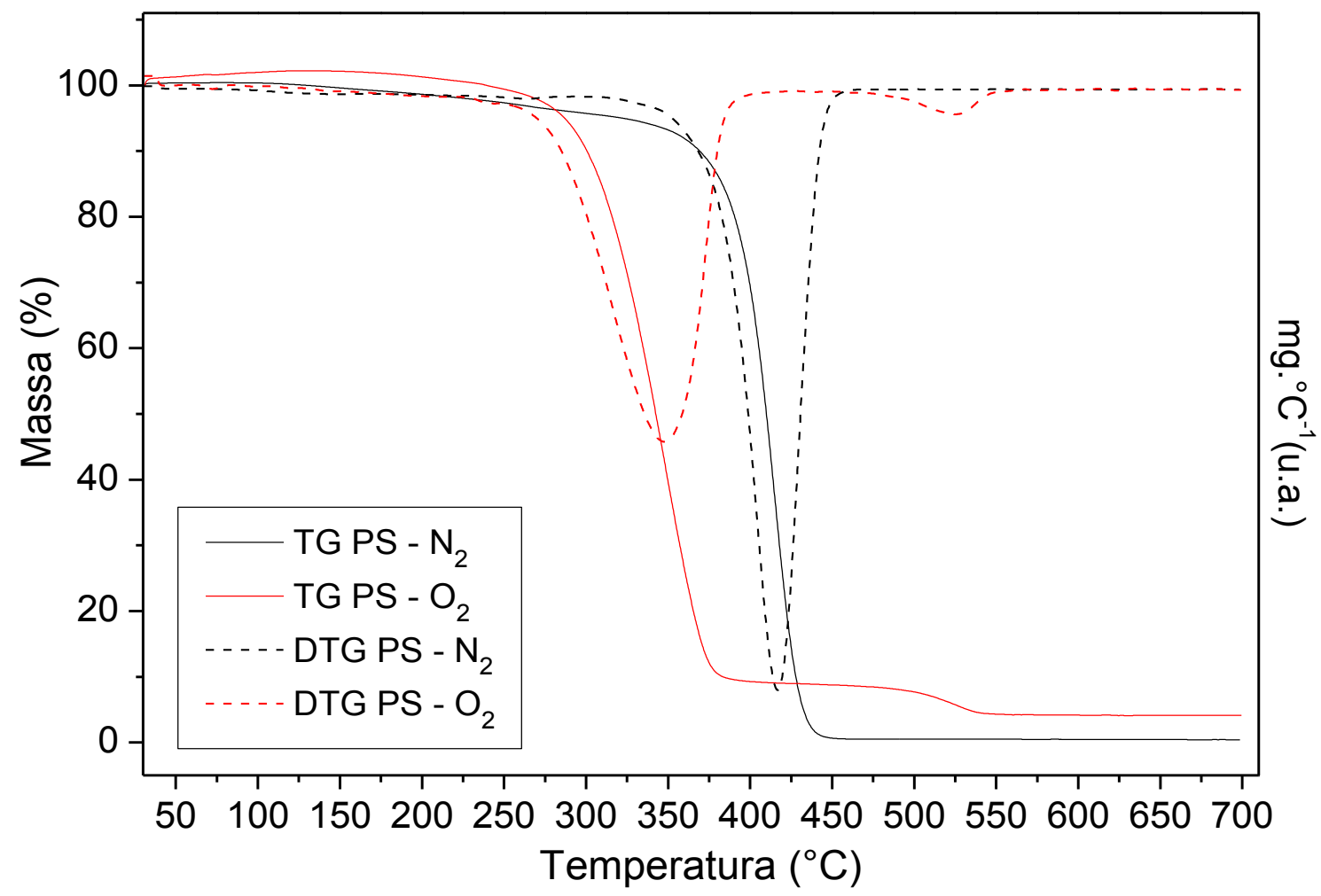

Figura 42 - Curvas de TG e DTG do poliestireno em atmosfera de nitrogênio e de oxigênio. 
São claras as diferenças de comportamento quando da utilização de atmosfera oxidativa em relação à atmosfera inerte. Em presença de oxigênio a decomposição se inicia ao redor de $275^{\circ} \mathrm{C}$ e há um segundo evento, no qual há perda de cerca de $5 \%$ de massa e ainda há cerca de $4 \%$ de massa residual. Em atmosfera inerte, o evento de decomposição é único, $100^{\circ} \mathrm{C}$ posterior, apresentando resíduo praticamente nulo.

Ao realizarmos as análises nos materiais enxertados, podemos perceber que para ambas as atmosferas os eventos referentes à matriz e ao monômero polimerizado estão presentes. Contudo, as amostras com baixos graus de enxertia, notadamente as enxertadas em solução de estireno/tolueno, apresentam curvas em geral bastante próximas à do polímero prístino.

Nas FIG. 43 e 44 estão apresentadas as curvas de TG e DTG dos materiais prístino e enxertados em ambos os solventes, para duas doses distintas de irradiação, em atmosfera inerte.

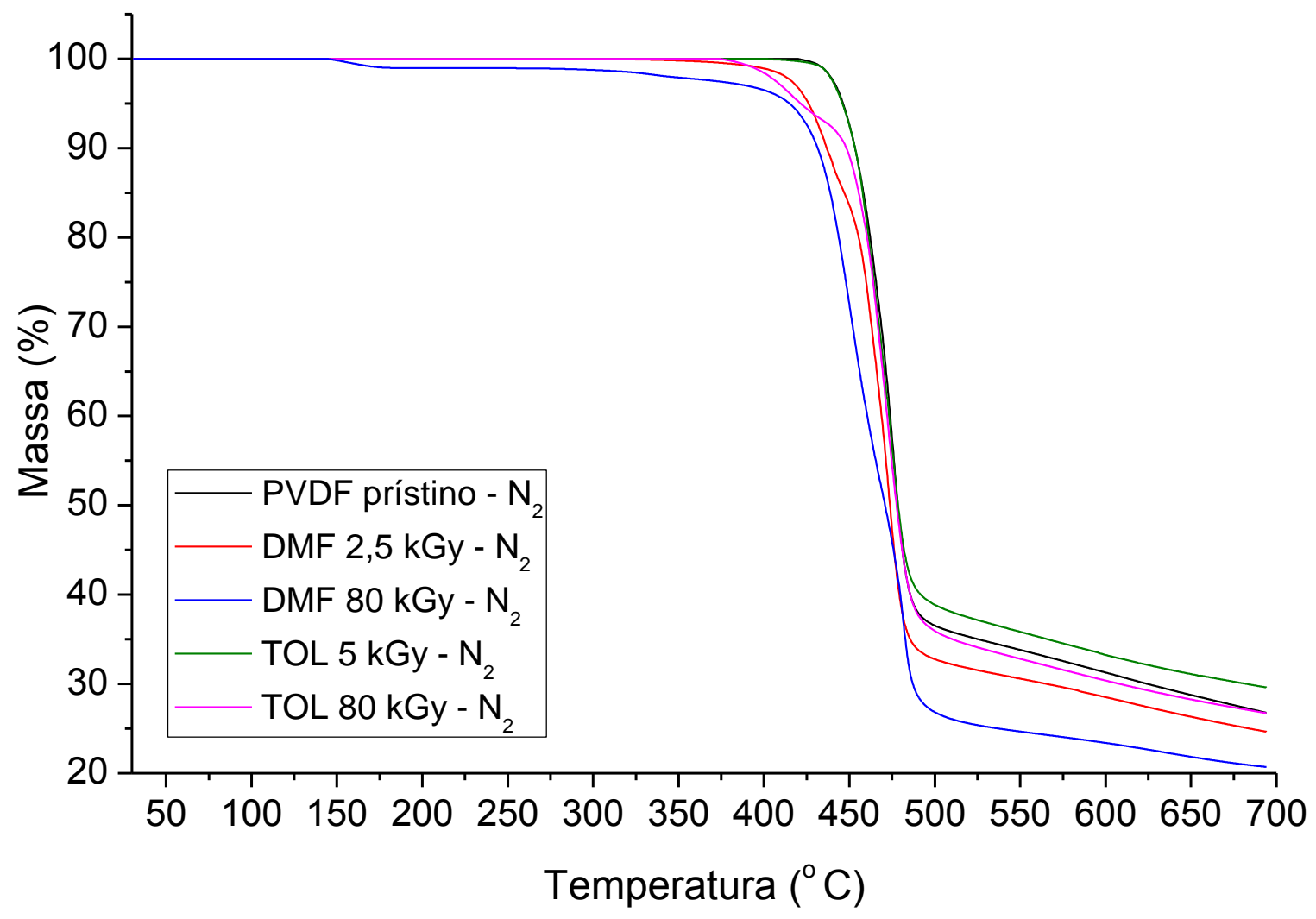

Figura 43 - Curvas de TG do polímero prístino, das amostras enxertadas em DMF e em tolueno em atmosfera de nitrogênio. 


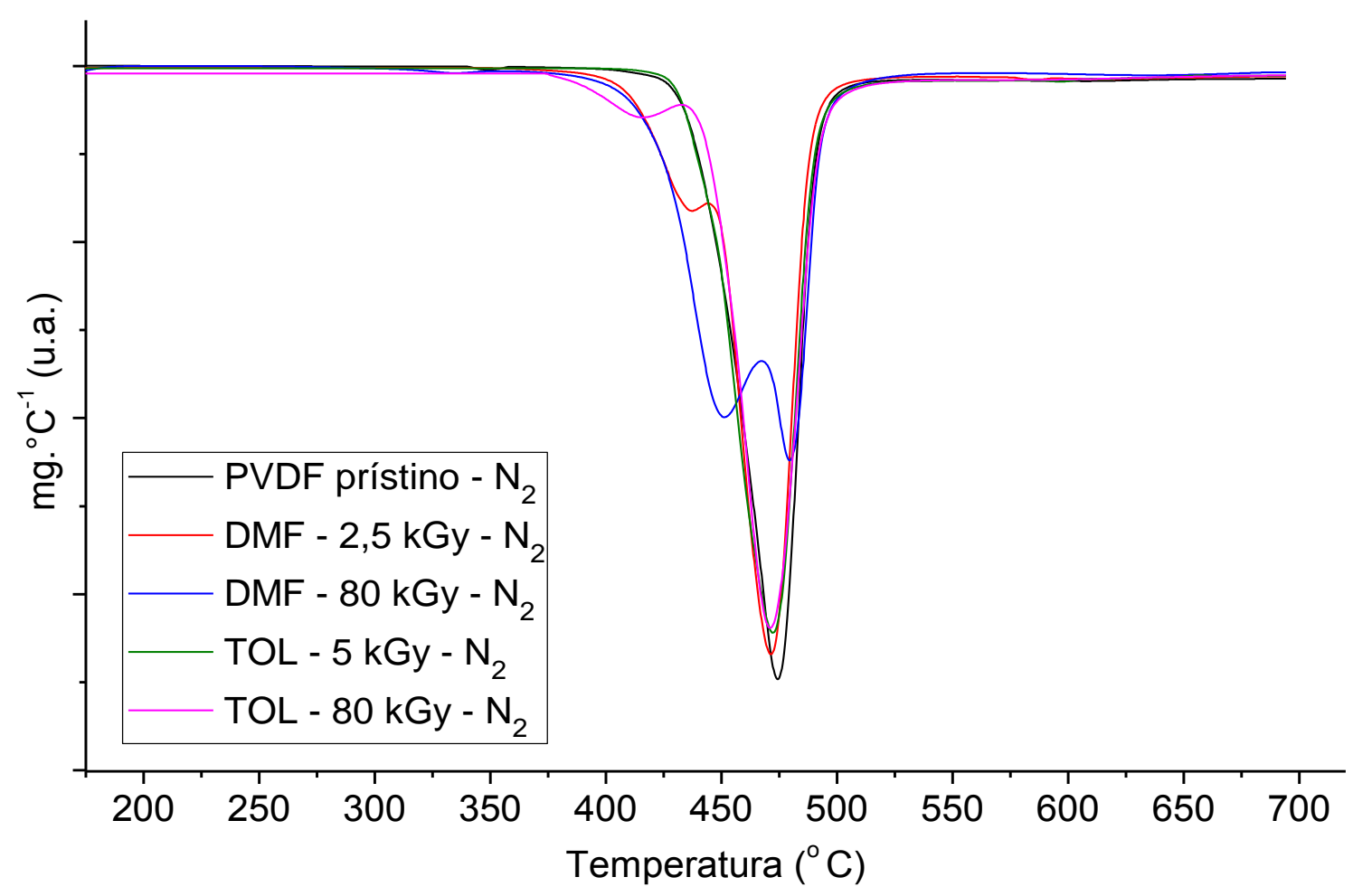

Figura 44 - Curvas de DTG do polímero prístino, das amostras enxertadas em DMF e em tolueno em atmosfera de nitrogênio.

Por meio das curvas podemos perceber a diferença quando do uso do tolueno em relação ao do DMF. O polímero prístino se decompõe em uma única etapa, com início em torno de $420^{\circ} \mathrm{C}$ e com um único pico ao redor de $473^{\circ} \mathrm{C}$. Já as amostras enxertadas apresentam um novo evento, atribuído ao estireno enxertado e a intensidade desse evento aumenta com o aumento do grau de enxertia, sendo que para o tolueno em doses baixas esse evento é quase imperceptível. Para as amostras que apresentam o novo evento de decomposição, este tem início ao redor de $375^{\circ} \mathrm{C}$, que é aproximadamente a temperatura em que ocorre a decomposição do poliestireno em atmosfera inerte, mostrada na FIG. 42. Podemos notar que a amostra enxertada em DMF com 80 kGy apresenta dois eventos com intensidades próximas, o que pode ser associado ao fato de a enxertia deste ser da ordem de $83 \%$; podemos assim afirmar que o primeiro evento representa a decomposição do estireno/poliestireno enxertado. Esta amostra também apresenta uma pequena perda de massa ao redor de $130{ }^{\circ} \mathrm{C}$, atribuída à decomposição de cadeias curtas de PS e liberação de solvente/monômero aprisionado no interior do material. 
Nas FIG. 45 e 46 apresentam-se as curvas de TG e DTG obtidas em atmosfera inerte de amostras prístina e enxertadas em DMF após sulfonação em solução com $2 \%$ e $10 \%$ de ácido clorossulfônico.

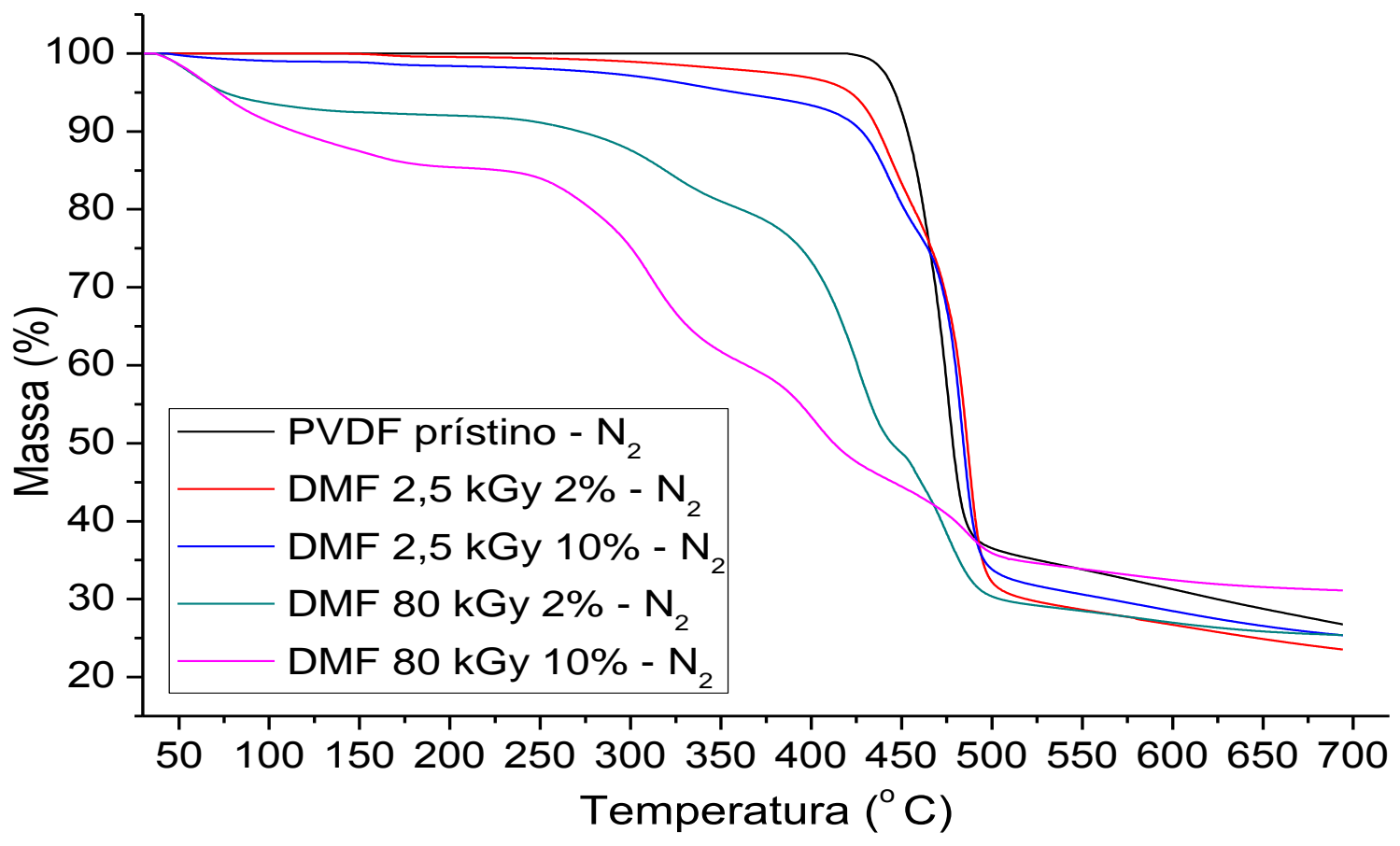

Figura 45 - Curvas de TG dos polímeros enxertados em DMF e sulfonados.

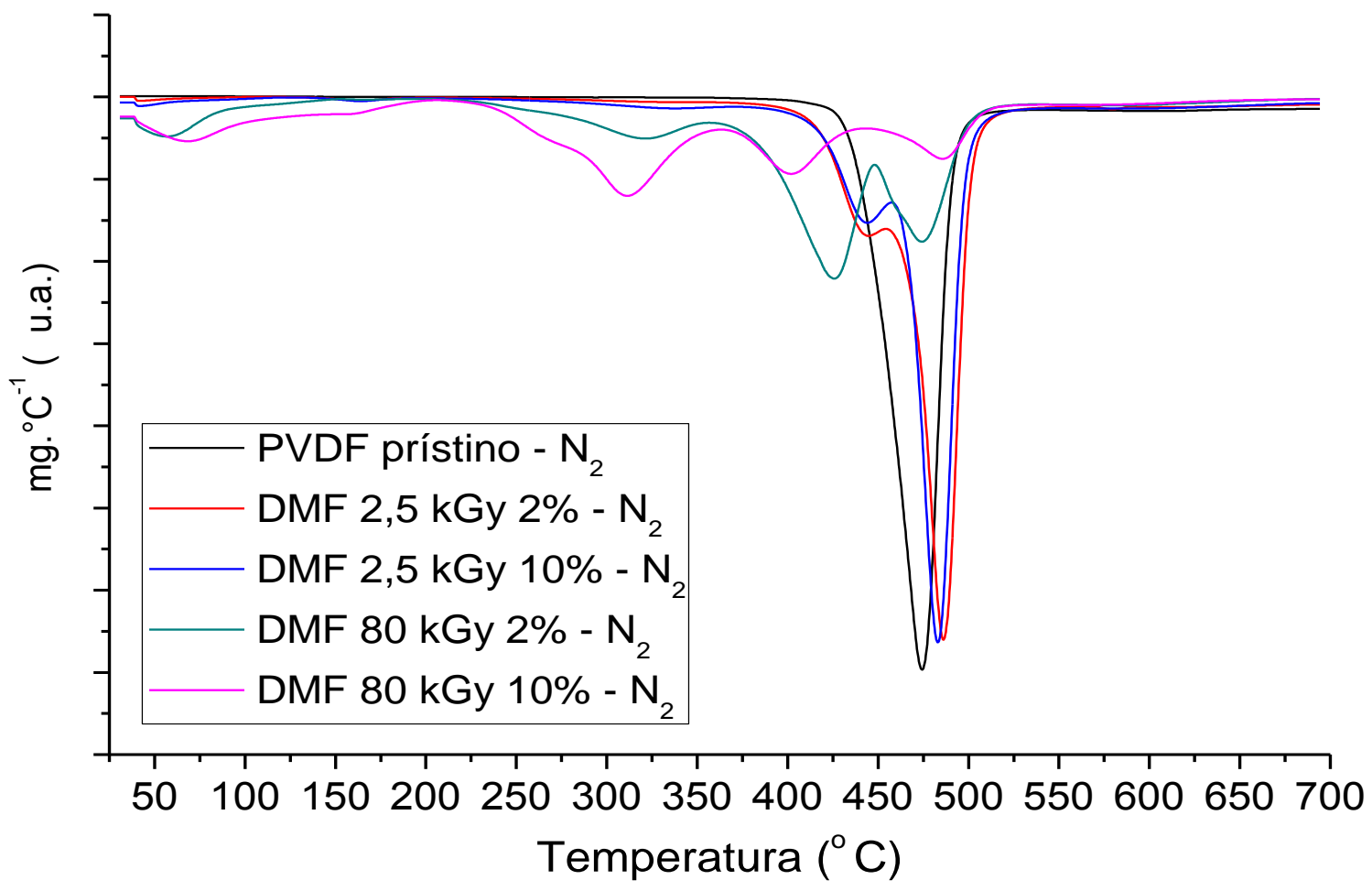

Figura 46 - Curvas de DTG dos polímeros enxertados em DMF e sulfonados. 
Nas FIG. 47 e 48 são apresentadas as curvas de TG e DTG obtidas em atmosfera inerte de amostras enxertadas em tolueno e sulfonadas, comparadas à curva do polímero prístino.

Para as amostras enxertadas em DMF, é notável a alteração provocada pela presença dos grupos sulfônicos, em que o primeiro evento é atribuído à perda de água residual, o segundo atribuído à liberação dos grupos sulfônicos, o terceiro à degradação do estireno e o último evento à degradação da matriz de PVDF. Já para as amostras enxertadas em tolueno, não é perceptível alteração provocada pela presença de grupos sulfônicos tanto com baixas quanto com altas doses de irradiação ou concentrações de ácido, o que pode ser explicado pela baixa enxertia e consequente baixa sulfonação, que também está relacionada com o baixo IEC.

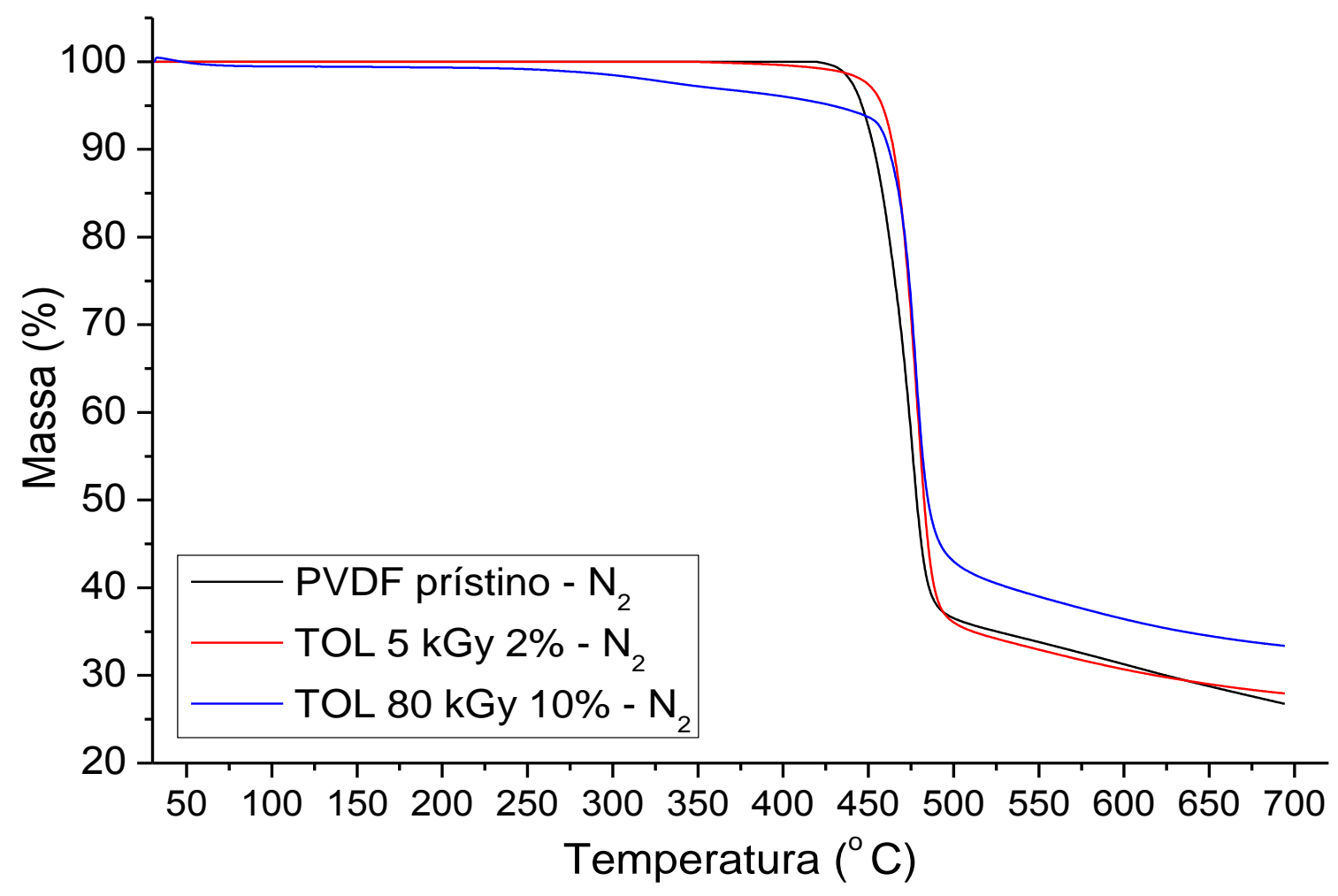

Figura 47 - Curvas de TG do polímero prístino, das amostras enxertadas em tolueno e sulfonadas. 


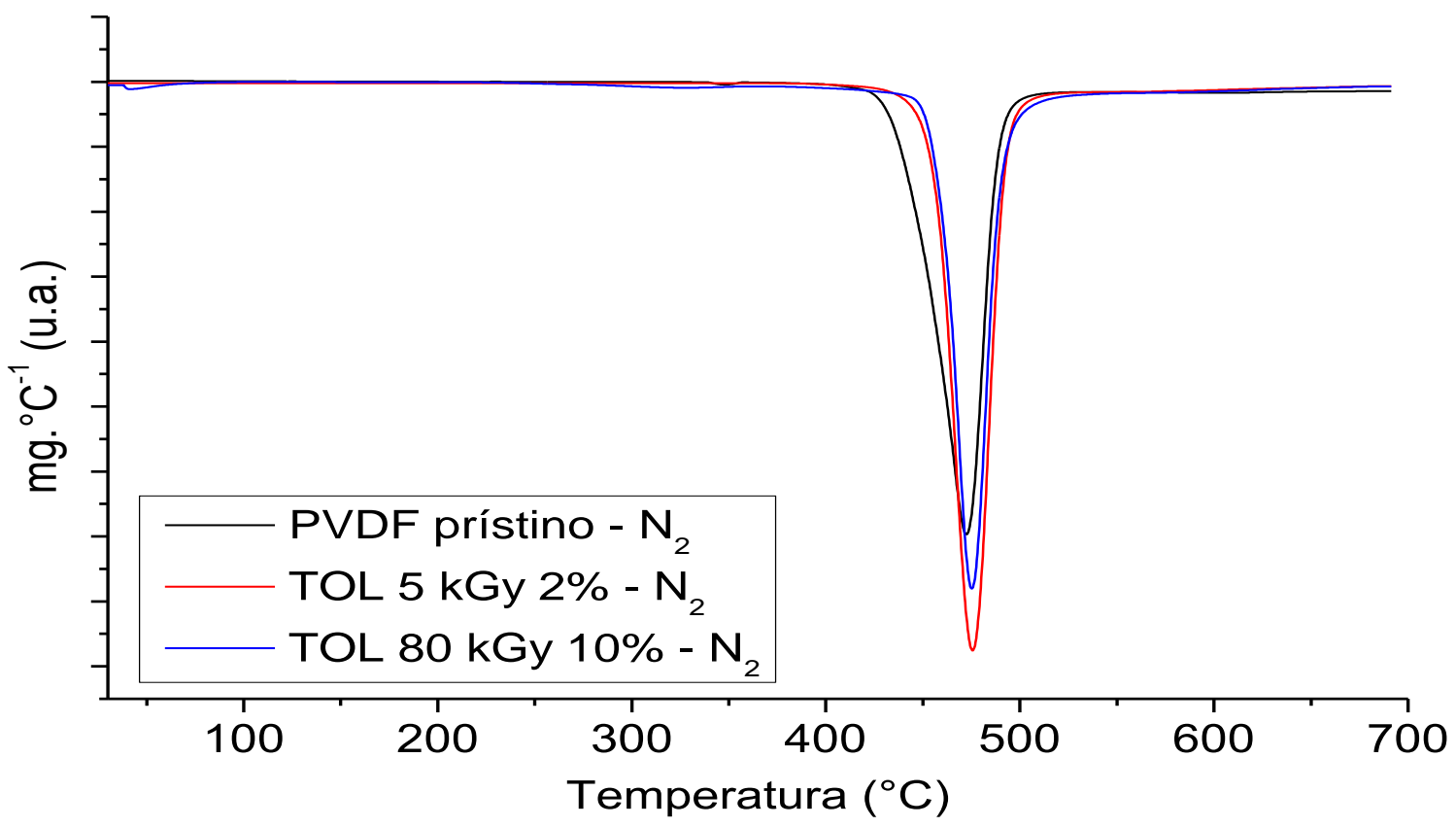

Figura 48 - Curvas de DTG do polímero prístino, das amostras enxertadas em tolueno e sulfonadas.

As curvas de TG e DTG obtidas em atmosfera oxidativa $\left(\mathrm{O}_{2}\right)$ das amostras enxertadas em tolueno estão apresentadas nas FIG. 49 e 50, respectivamente, e nas FIG. 51 e 52 são apresentadas as curvas das amostras enxertadas em DMF.

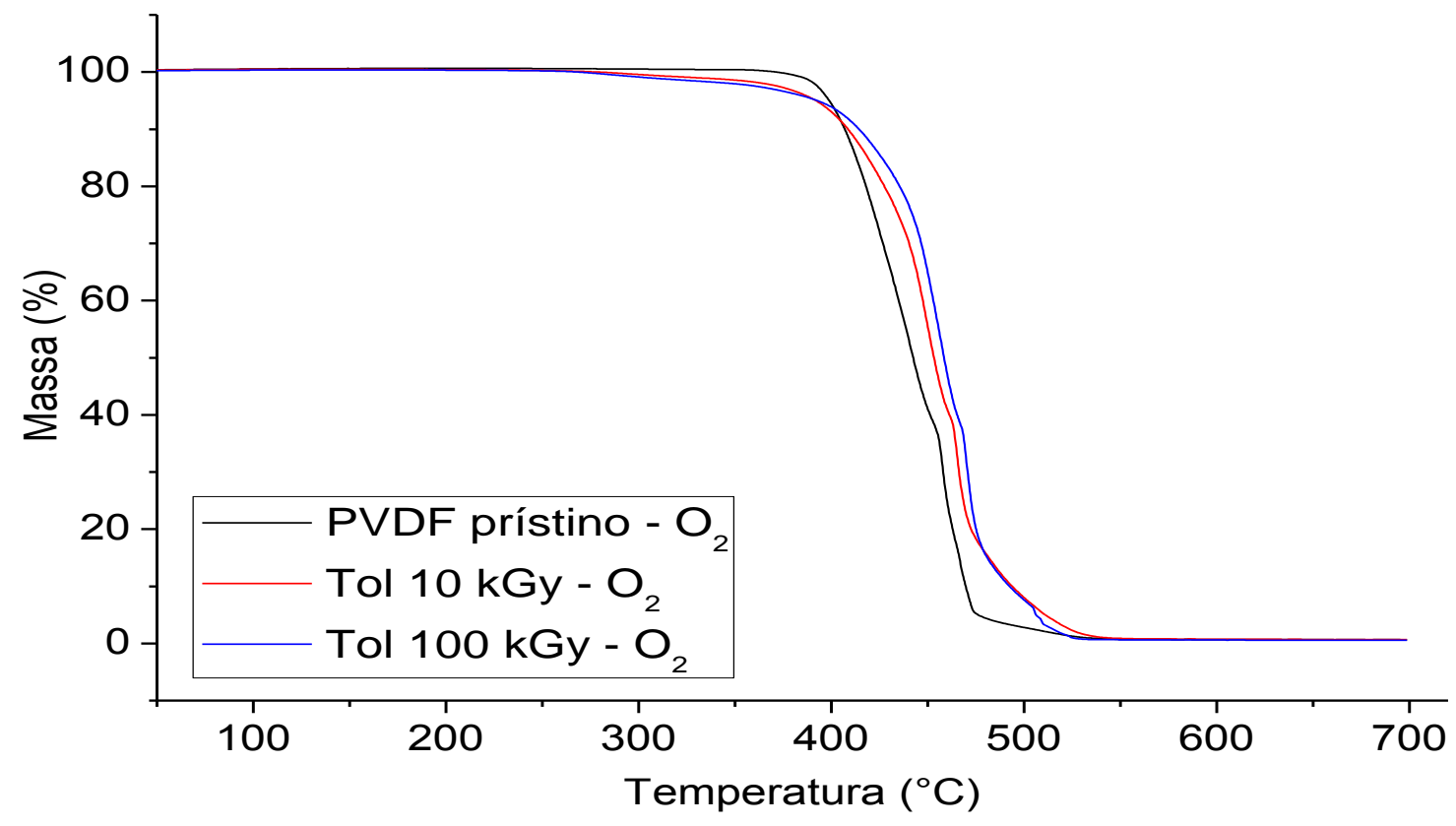

Figura 49 - Curvas de TG em atmosfera de $\mathrm{O}_{2}$ do polímero prístino e enxertado em tolueno. 


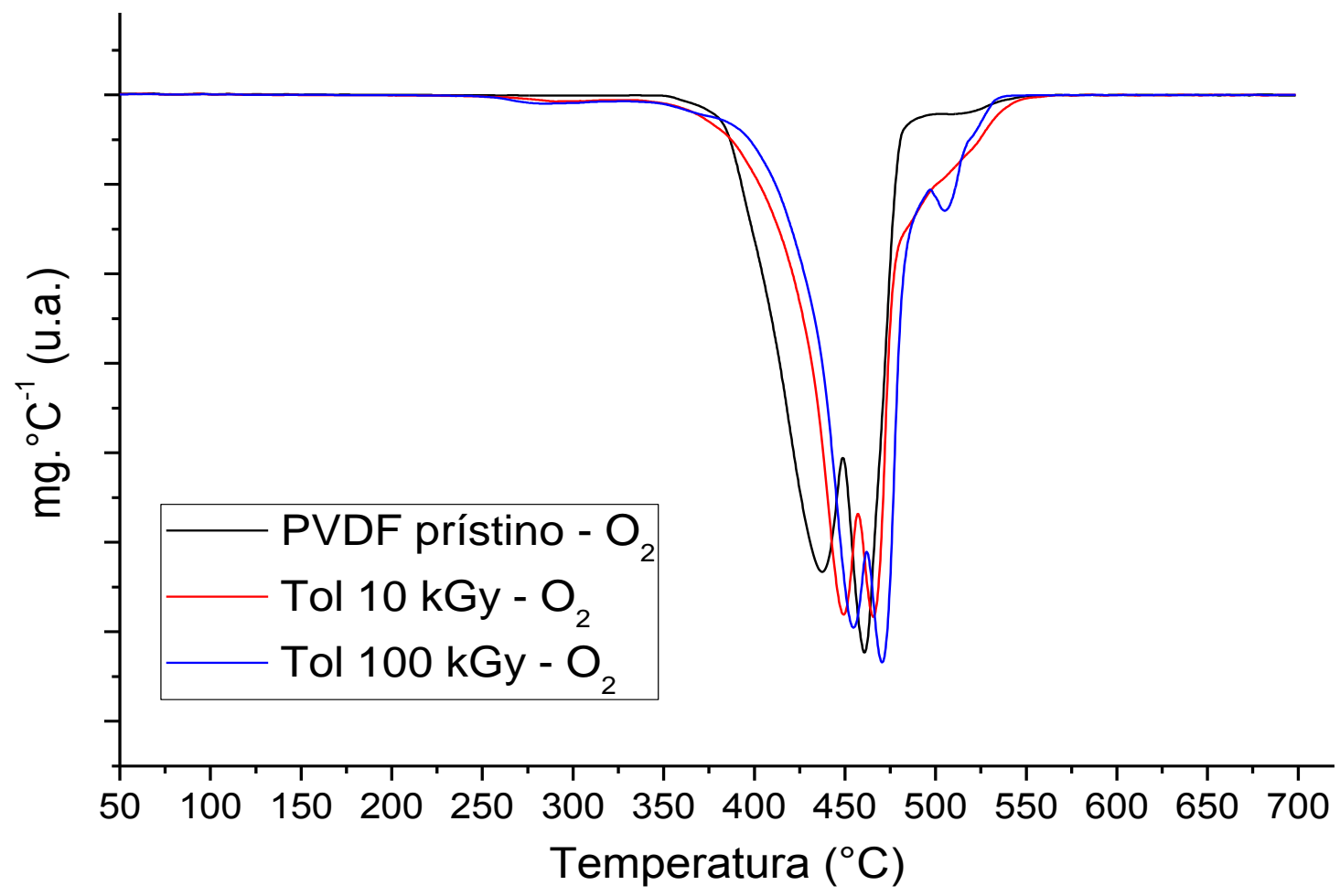

Figura 50 - Curvas de DTG em atmosfera de $\mathrm{O}_{2}$ do polímero prístino e enxertado em tolueno.

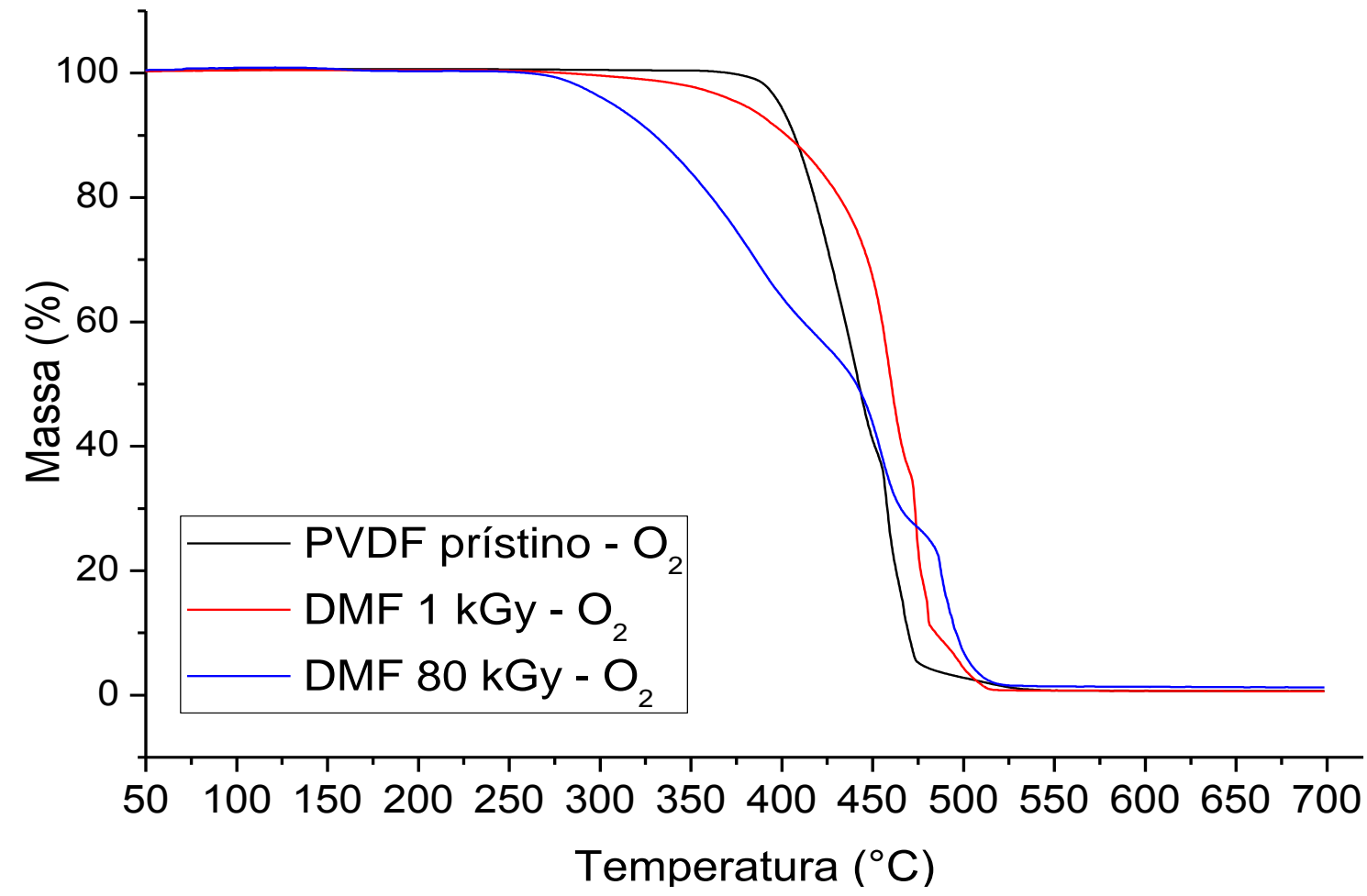

Figura 51 - Curvas de TG em atmosfera de $\mathrm{O}_{2}$ do polímero prístino e enxertado em DMF. 


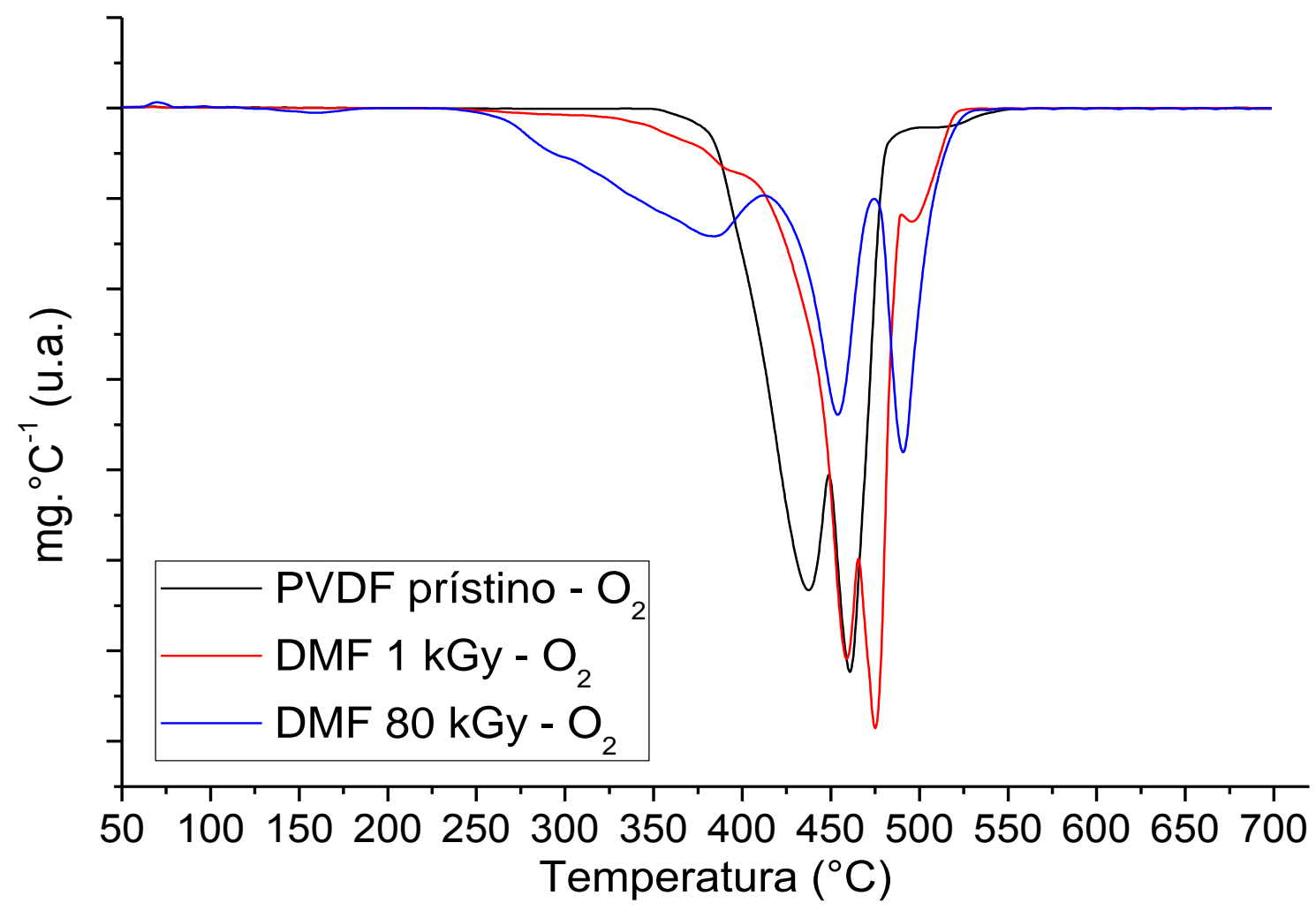

Figura 52 - Curvas de DTG em atmosfera de $\mathrm{O}_{2}$ do polímero prístino e enxertado em DMF.

Fica mais uma vez evidente a diferença proporcionada pela utilização de diferentes solventes durante a enxertia e a alteração provocada pela sulfonação. As amostras enxertadas em tolueno apresentam perfis de decomposição semelhante ao do polímero prístino. Já as enxertadas em DMF apresentam clara alteração provocada pelo estireno enxertado.

\subsection{Espectrometria no infravermelho (FT-IR)}

Na FIG. 53 são apresentados os espectros do poliestireno, do PVDF prístino e de uma amostra enxertada. Podemos perceber que a amostra enxertada apresenta tanto os picos característicos da matriz polimérica quanto os picos provenientes do monômero. 
É possível notar o aparecimento de novas bandas quando o polímero enxertado é comparado ao polímero prístino. Essas novas bandas estão entre $3100 \mathrm{~cm}^{-1}$ e $2850 \mathrm{~cm}^{-1}$,típicas do poliestireno, atribuídas à vibração de estiramento da ligação C-H do anel aromático; entre 1601-1450 cm${ }^{-1}$, atribuídas à deformação de estiramento das ligações $\mathrm{C}=\mathrm{C}$ do anel aromático; entre 695-705 $\mathrm{cm}^{-1}$ associadas à vibração fora do plano da ligação $\mathrm{C}-\mathrm{H}$ e uma banda bastante intensa em $700 \mathrm{~cm}^{-1}$ atribuída à deformação fora do plano do anel, possivelmente também sobreposta com a anterior $[28,96]$.

Já na FIG. 54 apresenta-se os espectros de infravermelho de PVDF prístino, enxertado em DMF com dose de irradiação de 80 kGy e esta mesma amostra depois de sulfonada com a maior concentração de ácido. 


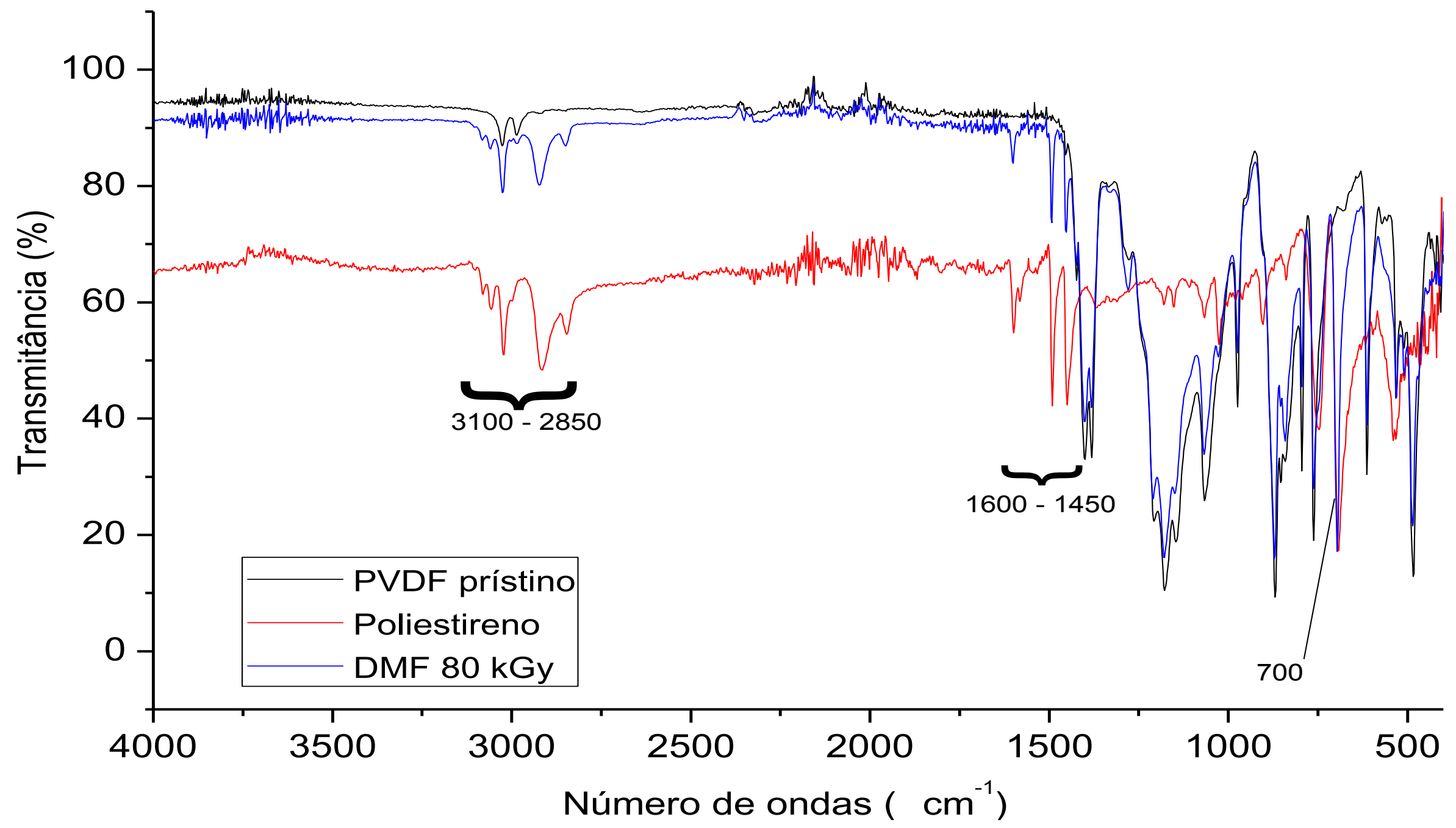

Figura 53 - Espectros de infravermelho das amostras de PVDF prístino, enxertado em DMF e em tolueno. 


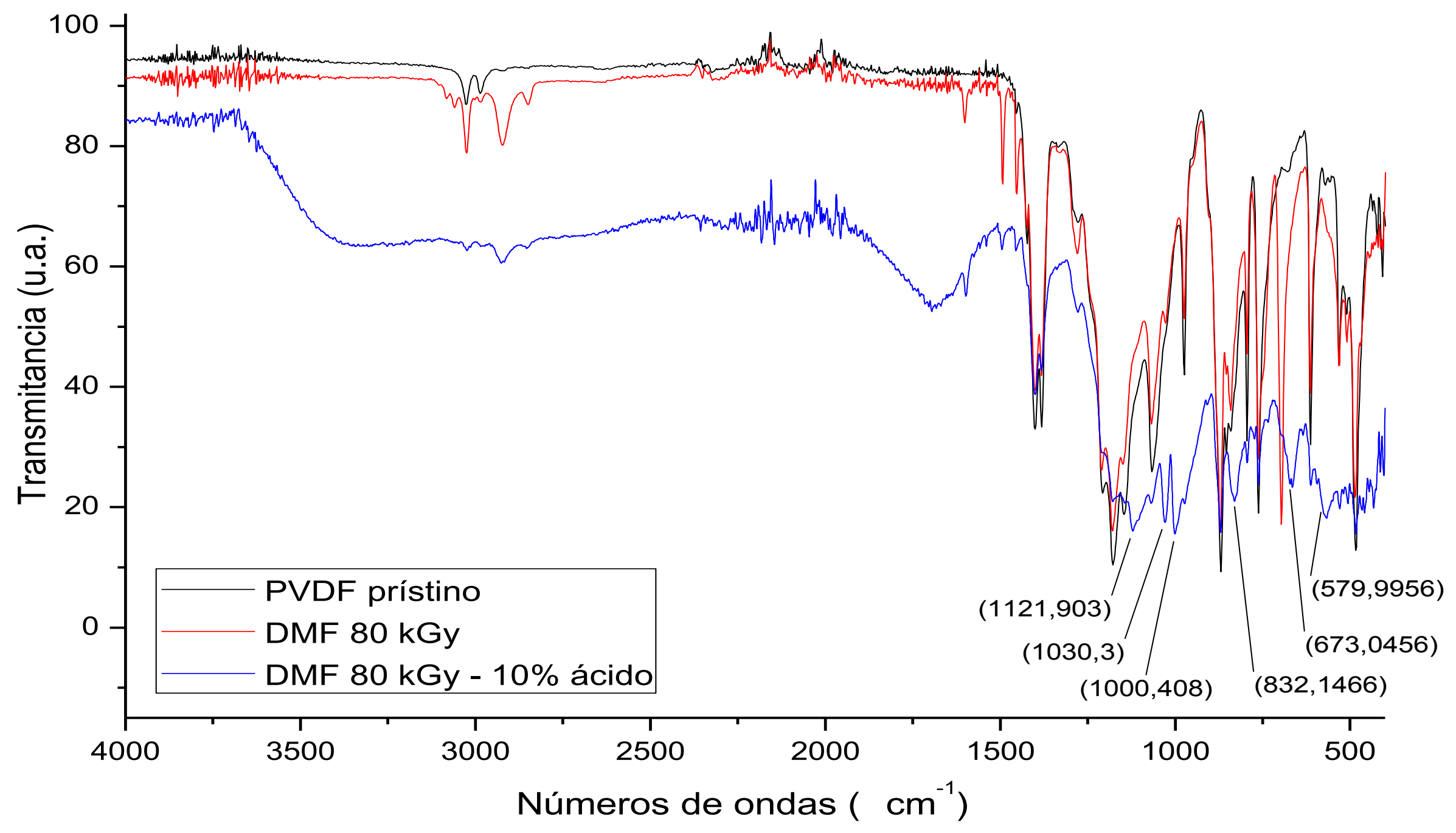

Figura 54 - Espectros de FT-IR das amostras de PVDF prístino, enxertado em DMF e, a seguir, sulfonado. 
Podemos notar os picos destacados, atribuídos aos grupos sulfônicos: em $580 \mathrm{~cm}^{-1}$, atribuído à deformação de tesoura dos grupos sulfônicos; em 1030 $\mathrm{cm}^{-1}$, atribuído ao estiramento simétrico do grupo $\mathrm{SO}_{3}$; em $1000 \mathrm{~cm}^{-1}$ e em 838 $\mathrm{cm}^{-1}$, atribuídos à absorção dos anéis para-substituídos. A inserção dos grupos sulfônicos na posição para dos anéis parece ser predominante, uma vez que seria a posição mais favorável. O pico em $673 \mathrm{~cm}^{-1}$ pode ser atribuído ao estiramento da ligação C-S no anel e o pico em $1121 \mathrm{~cm}^{-1}$ à banda de estiramento antissimétrico do grupo $\mathrm{SO}_{2}$ do grupo sulfônico hidratado. Podemos também perceber a presença de água ligada a esses grupos e que não pôde ser totalmente removida durante a secagem, encobrindo uma grande região entre 3500 e $2500 \mathrm{~cm}^{-1}[28,37,96]$.

Na FIG. 55 estão apresentados os espectros de FT-IR de amostras sulfonadas depois de enxertadas em tolueno e em DMF, nos quais podemos perceber que os picos atribuídos aos grupos sulfônicos também estão presentes na amostra enxertada em tolueno, mas com intensidades menores. Isso pode ser explicado pelo fato de as superfícies dos filmes entrarem em contato com o cristal do equipamento e, nas amostras enxertadas em tolueno, o enxerto estar aderido superficialmente nos filmes, e com todos os grupos sulfônicos ali localizados. 


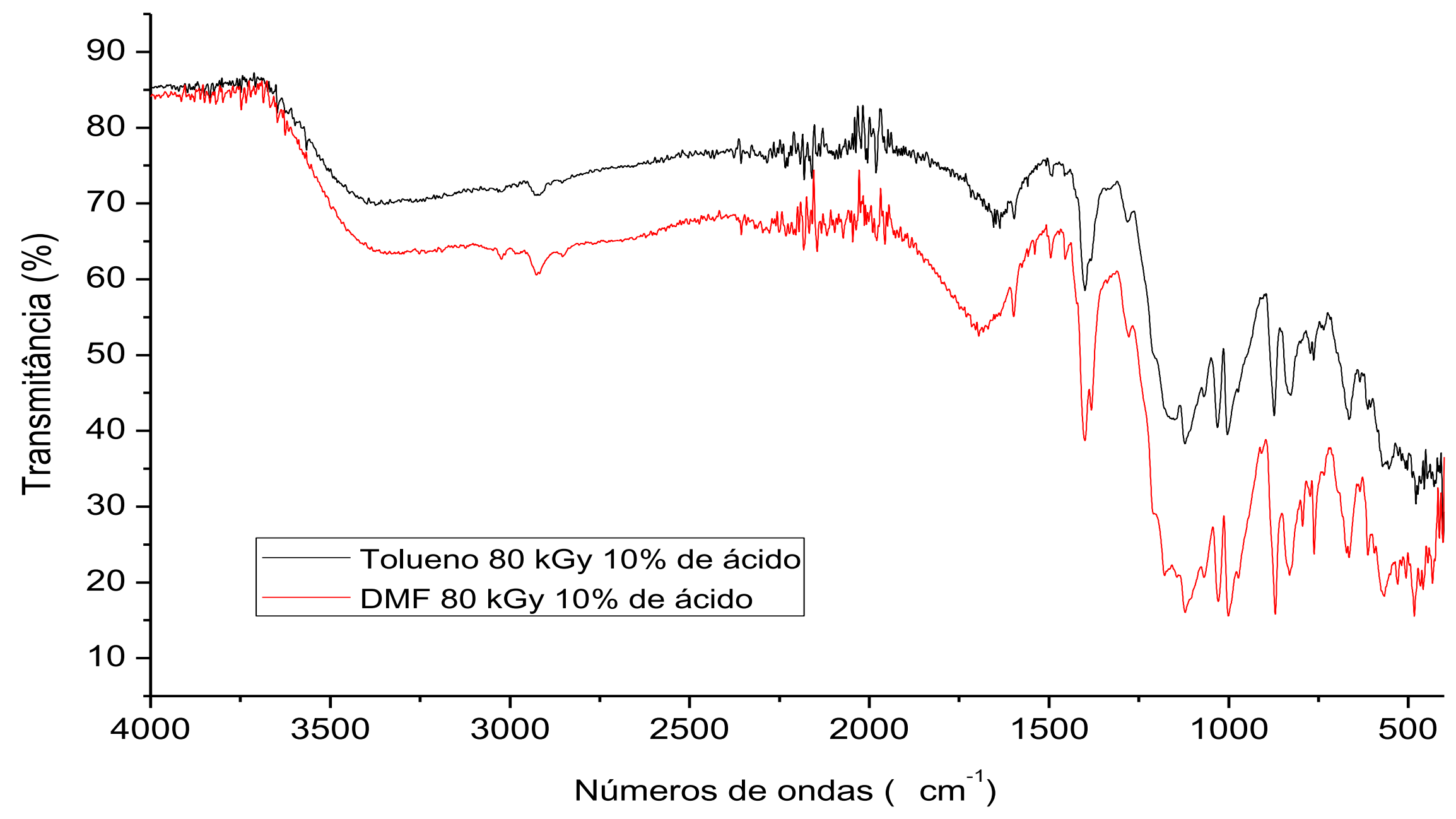

Figura 55 - Espectros de FT-IR de amostras sulfonadas depois de enxertadas em tolueno e em DMF. 
Baseados nesses resultados, podemos dizer que foi obtida estrutura formada por uma cadeia principal de PVDF enxertado com estireno e com grupos sulfônicos ligados aos anéis aromáticos, predominantemente na posição para, como representado anteriormente na FIG. 12, embora os resultados de IEC permitam afirmar que não foi atingido grau de sulfonação de $100 \%$ e, portanto, não seriam todos os anéis aromáticos que conteriam grupos sulfônicos ligados.

\subsection{Metalização e atuação}

$\mathrm{Na}$ FIG. 56 são apresentadas fotografias das amostras de PVDF enxertadas em DMF posteriormente sulfonadas com 10\% de ácido clorossulfônico para as doses de 1, 10 e 40 kGy após metalização (a, b e c, respectivamente) e a amostra de Nafion 117 metalizada pelo mesmo procedimento (d). Podemos notar a deposição de partículas de prata nas amostras, embora o recobrimento no Nafion pareça ter ocorrido de maneira mais eficiente.

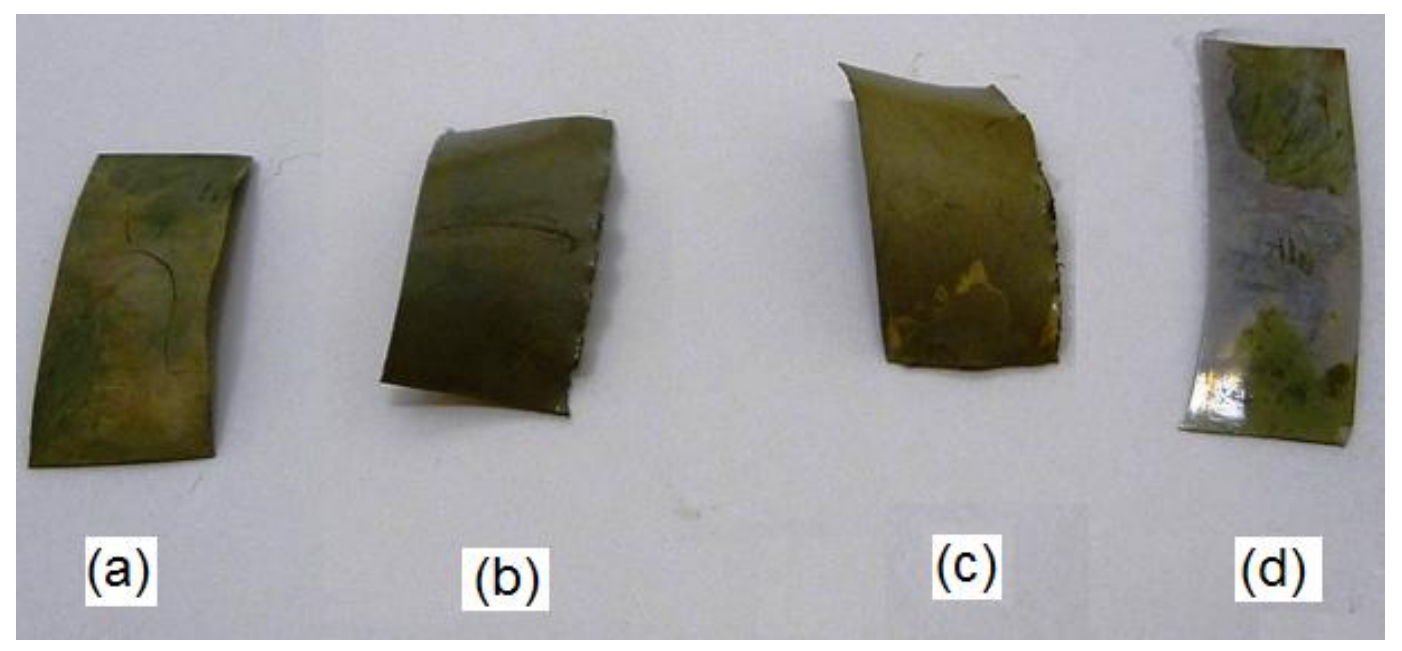

Figura 56 - Amostras sulfonadas após etapa de metalização.

Ao realizar o teste de movimentação dos compósitos produzidos, não foi observada resposta em nenhuma das amostras e para nenhuma das configurações testadas, mesmo para o Nafion, material de referência largamente utilizado. Fica evidente, portanto, que a metodologia adaptada, utilizada para a metalização não se mostrou eficiente no que se refere à penetração das partículas condutoras nem à deposição de filme condutor superficial. Com base 
nas micrografias apresentadas anteriormente, é possível que os poros formados, assim como a rugosidade formada nas superfícies das amostras sulfonadas, não sejam apropriados para que o filme metálico entre adequadamente em contato com o polímero.

A prata, embora seja uma boa condutora elétrica, pode oxidar mais facilmente que a platina que ainda é o metal mais amplamente utilizado em IPMC, ou o ouro, também bastante utilizado, principalmente na segunda etapa de metalização para formar eletrodos com maior condutividade elétrica e com menores custos [67, 68, 69, 78]. Portanto, a prata apresenta grande potencial para a metalização, o que pode ser comprovado pelo número de autores que a estudam, visando principalmente a redução de custos e melhora na atuação, embora a platina ainda predomine. Outro fator que pode ter contribuído para a ausência de atuação é a não realização de abrasão superficial das membranas antes da metalização, como descrito por Oguro [79] e que talvez pudesse originar superfícies mais adequadamente metalizadas.

Como mencionado anteriormente, Gubler e colaboradores, do Instituto Paul Scherrer, afirmaram que enxertias ao redor de 25 a $30 \%$ apresentam bons resultados para aplicação em células a combustível do tipo PEM, de maneira a não degradar as propriedades da matriz polimérica e apresentar capacidades de troca iônica adequadas após sulfonação [60]. É possível que o mesmo nível mínimo de enxertia seja válido para que o PVDF enxertado e sulfonado apresente propriedades adequadas quando aplicado como IPMC. Isso pode ser verificado comparando-se os graus de enxertia obtidos com as capacidades de troca iônica alcançadas e as micrografias. As amostras enxertadas em DMF com 5 kGy apresentam enxertias da ordem de 35\% e com a sulfonação utilizando 10\% de ácido clorossulfônico ainda apresentam IEC abaixo do Nafion mas com o inicio da formação de poros, vistos nas micrografias e, caso consiga-se valores de IEC mais próximos do IEC teórico, graus de enxertia acima de $30 \%$ e abaixo de $80 \%$ podem se mostrar promissores se adequadamente sulfonados e metalizados. 


\section{CONCLUSÕES}

É possível obter material enxertado e sulfonado com capacidade de troca iônica necessária à confecção de atuador polimérico do tipo IPMC, embora maiores estudos ainda sejam necessários.

A enxertia de estireno em PVDF é possível nas condições estudadas, sendo que os diferentes solventes utilizados favoreceram diferentes formas de enxertia. Enquanto o tolueno proporciona uma enxertia superficial, possivelmente com cadeias mais longas e em menor grau, a DMF proporcionou maiores níveis de enxertia, de maneira mais homogênea, penetrando nas camadas mais internas do PVDF, o que foi comprovado por meio das micrografias.

As capacidades de troca iônica se mostraram dependentes do grau de enxertia e da forma como a enxertia ocorre, o que faz com que deva ser sempre considerada a forma com que o solvente interage com o monômero, com a matriz polimérica, com o copolímero formado e com a radiação ionizante.

As capacidades de troca iônica também se mostraram variáveis com a concentração de ácido clorossulfônico utilizada na reação de sulfonação, comprovado pelo cálculo de IEC, embora a adoção de metodologia diferente possa permitir a obtenção de valores mais próximos dos valores teóricos.

A espectroscopia no infravermelho confirmou a presença de estireno enxertado e dos grupos iônicos por meio de novos picos característicos, ausentes no polímero prístino, o que está de acordo com a literatura.

Não foi possível obter movimentação de nenhuma das amostras produzidas. Entretanto, tal fato também não foi observado para o Nafion, o que nos permite dizer que a metalização realizada não foi eficaz, já que, do ponto de vista de capacidade de troca iônica, alguns materiais produzidos igualam ou superam o Nafion. 
Tendo em vista as características e morfologias dos materiais obtidos, aqueles que se mostram mais promissores à aplicação na produção de IPMCs são os materiais enxertados em solução de estireno/DMF em doses maiores que 2,5 e menores que 80 kGy e por isso merecem mais atenção em estudos futuros para o aprimoramento das etapas de enxertia, sulfonação e metalização. 


\section{PERSPECTIVAS FUTURAS}

Estudar diferentes concentrações de solvente/monômero, diferentes solventes e diferentes métodos de irradiação (pré-irradiação e peroxidação) para que se encontre a melhor forma de promover enxertia suficiente sem que as propriedades da matriz sejam severamente degradadas.

Aperfeiçoar e estudar os parâmetros envolvidos na sulfonação, utilizando diferentes concentrações de ácido, tempos e temperaturas de reação ou solvente do ácido durante a sulfonação, visando a uma maior aproximação dos valores teóricos e que dispensaria a irradiação com doses muito elevadas.

Desenvolver uma metodologia eficaz para a etapa de metalização, para que seja possível produzir IPMCs que apresentem movimentação a partir dos materiais produzidos.

Estudar os comportamentos térmicos do PVDF quanto ao impacto de cada etapa na modificação de sua cristalinidade, ou seja, na cristalinidade das regiões não enxertadas, a fim de se obter um material que preserve parte de suas propriedades mecânicas sem resultar em um material frágil.

Estudar a modificação de outros polímeros (fluorados ou não) como o ETFE, FEP, PFA e PP para que sejam comparadas as características de cada um frente à enxertia induzida por radiação, sulfonação e metalização e as propriedades de IPMCs com eles produzidos.

Testar os materiais com capacidades de troca iônica obtidos em outras áreas, em que esta propriedade seja necessária, como em células a combustível para avaliar a viabilidade dessa rota de modificação para outras aplicações. 


\section{REFERÊNCIAS BIBLIOGRÁFICAS}

1 AKCELRUD, L. Fundamentos da ciência dos polímeros. São Paulo: Manole, 2007.

2 CANEVAROLO JÚNIOR, S.V. Ciência dos polímeros: um texto básico para tecnólogos e engenheiros. São Paulo: Artliber, 2004.

3 OSADA, Y.; HASEBE, M. Electrically activated mechanochemical devices using poly-electrolyte gels, Chem. Lett., p. 1285-1288, 1985.

4 HARA, S.; ZAMA, T.; TAKASHIMA, W.; KANETO, K. Artificial muscles based on polypyrrole actuators with large strain and stress induced electrically, Polym. J. v.36, n.2, p.151-161, 2004.

5 HARA, S.; ZAMA, T.; TAKASHIMA, W.; KANETO, K.; Gel-like polypyrrole based artificial muscles with extremely large strain, Polym. J. v. 36, n. 11, p. 933-936, 2004.

6 SEGALMANT, D.J.; WITKOWSKIT, W.R.; ADOLFT, D.E.; SHAHINPOOR, M. Theory and application of electrically controlled polymeric gels, Smart Mater. Struct. v. 1, p. 95-100, 1992.

7 BAR-COHEN, Y. (Ed.) Electroactive polymer (EAP) actuators as artificial muscles: reality, potencial and challenges, 2.ed. Bellingham, WA: SPIE, 2004.

8 MIRFAKHRAI, T.; MADDEN, J.D.W.; BAUGHMAN, R.H. Polymer artificial muscles, Mater. Today, v. 10, n. 4, p. 30-38, 2007.

9 KIKUCHI, K.; TSUCHITANI, S. Nafion®-based polymer actuators with ionic liquids as solvent incorporated at room temperature, J. Appl. Phys, v.106, p. 053519-1/8, 2009.

10 NASEF, M.M.; HEGAZY, E.-S.A. Preparation and applications of ion exchange membranes by radiation-induced graft copolymerization of polar monomers onto non-polar films. Prog. Polym. Sci. v. 29, p. 499-561, 2004.

11 SHAHINPOOR, M.; KIM, K.J. Ionic polymer-metal composites: I. Fundamentals. Smart Mater. Struct. v. 10, p. 819-833, 2001. 
12 BOUTEVIN, B.; PIETRASANTA, Y.; ROBIN, J-J. Synthese et application de copolymeres greffes a base de polyfluorure de vinylidene - I. Eur. Polym. J. v. 27, n. 8, p. 815-820, 1991.

13 FARGERE, T., ABDENNADHER, M., DELMAS, M., BOUTEVIN, B. Synthèse et caractéristiques mécanique des copolymères d'éthylène et d'acétate de vinyle greffés styrène (EVA-g-S) par la méthode d'ozonisation. Eur. Polym. J. v. 31, n. 10, p. 923-930, 1995.

14 GUBLER, L.; PROST, N.; GURSEL, S.A.; SCHERER, G.G. Proton exchange membranes prepared by radiation grafting of styrene/divinylbenzene onto poly(ethylene-alt-tetrafluoroethylene) for low temperature fuel cells. Solid State Ionics, v. 176, p. 2849 - 2860, 2005.

15 GURSEL, S.A.; PADESTE, C.; SOLAK, H.H.; SCHERER, G.G. Microstructured polymer films by X-ray lithographic exposure and grafting. Nucl. Instrum. Meth. B, v. 236, p. 449-455, 2005.

16 GUBLER, L.; GURSEL, S.A.; SCHERER, G.G. Radiation grafted membranes for polymer electrolyte fuel cells. Fuel Cells, v. 5, p. 317-335, 2005.

17 GUBLER, L.; SLASKI, M.; WOKAUN, A.; SCHERER, G.G. Advanced monomer combination for radiation grafted fuel cell membranes. Electrochem. Commun. n. 8, p. 1215-1219, 2006.

18 GUPTA, B.; SCHERER, G.G. Proton exchange membranes by radiation grafting of styrene onto FEP films. I: thermal characteristics of copolymer membranes. J. Appl. Polym. Sci. v. 50, p. 2129-2134, 1993.

19 GUPTA, B.; BUECHI, F.N.; SCHERER, G.G.; CHAPIRO, A. Development of membranes by radiation grafting of acrylamide into polyethylene films: influence of synthesis condition. J. Appl. Polym. Sci. v. 5, p. 493-499, 1994.

20 GUBLER, L.; BECK, N.; GURSEL, S.A.; HAJBOLOURI, F.; KRAMER, D.; REINER, A.; STEIGER, B.; SCHERER, G.G.; WOKAUN, A.; RAJESH, B.; THAMPI, K.R. Materials for polymer electrolyte fuel cells. Chimia. v. 58, p. 826832, 2004.

21 NASEF, M.M.; SAIDI, H.; NOR, H.M.; DAHLAN, K.Z.M.; HASHIM, K. Cation exchange membranes by radiation-induced graft copolymerization of styrene 
onto PFA copolymer films. I: Preparation and characterization of the graft copolymer. J. Appl. Polym. Sci. v. 73, p. 2035-2102, 1999.

22 NASEF, M.M.; SAIDI, H.; NOR, H.M.; FOO, O.M. Cation exchange membranes by radiation-induced graft copolymerization of styrene onto PFA copolymer films. II: characterization of sulfonated graft copolymer membranes. J. Appl. Polym. Sci. v. 76, p. 1-11, 2002.

23 NASEF, M.M.; SAIDI, H. Preparation of crosslinked cation exchange membranes by radiation grafting of styrene/divinylbenzene mixtures onto PFA films. J. Membrane Sci. v. 216, p. 27-38, 2003.

24 NASEF, M.M.; SAIDI, H.; DAHLAN, K.Z.M. Electron bean irradiation effects on ethylene-tetrafluoroethylene copolymer films, Radiat. Phys. Chem. v. 68, p. 875-883, 2003.

25 NASEF, M.M.; DAHLAN, K.Z.M. Electron irradiation effects on partially fluorinated polymer films: Structure-property relationships. Nucl. Instrum. Meth. B. v. 201, p. 604-614, 2003.

26 NASEF, M.M.; SAIDI, H.; NOR, H.M. Proton Exchange membranes prepared by simultaneous radiation grafting of styrene onto poly(tetrafluoroethylene) films. I: Effect of grafting conditions. J. Appl. Polym. Sci. v. 76, p. 220-227, 2000.

27 NASEF, M.M. Effect of solvents on radiation-induced grafting of styrene onto fluorinated polymer films. Polym. Int. v. 50, p. 338-346, 2001.

28 CLOCHARD, M.-C.; BERTHELOT, T.; BAUDIN, C.; BETZ, N.; BALANZAT, E.; GÉBEL, G.; MORIND, A. lon track grafting: A way of producing low-cost and highly proton conductive membranes for fuel cell applications. J. Power Sources v. 195, p. 223-231, 2010.

29 CHARLESBY, A. The effects of ionizing radiation on polymers. In: CLEGG, D. W.; COLLYER, A. A. (Ed.), Irradiation effects on polymers, New York, NY: Elsevier, 1991, p. 39-78.

30 BHATTACHARYA, A.; MISRA, B.N. Grafting: a versatile means to modify polymers Techniques, factors and applications. Prog. Polym. Sci. v. 29, n. 8, p. 767-814, 2004. 
31 CHAPIRO, A. XIlth international meeting on radiation processing Avignon 2530 March 2001 (Polymer irradiation: past-present and future). Radiat. Phys. Chem. v. 63, p. 207-209, 2002.

32 BhATtACHARYA, A. Radiation and industrial polymers. Prog. Polym. Sci. v. 25, p. 371-401, 2000.

33 QIU, J.; NI, J.; SHAI, M.; PENG, J.; ZHOU, H.; LI, J.; WEI, G. Radiation grafting of styrene and maleic anhydride onto PTFE membranes and sequent sulfonation for applications of vanadium redox battery. Radiat. Phys. Chem. v. 76. p. 1703-1707, 2007.

34 LAPPAN, U.; GEIBLER, U.; UHLMANN, S. Radiation-induced grafting of styrene into radiation-modified fluoropolymer films. Nucl. Instrum. Methods. v. 236. p. 413-419, 2005.

35 SUGIYAMA, S.; TSUNEDA, S.; SAITO, K.; FURUSAKI, S.; SUGO, T.; MAKUUCHI, K. Attachment of sulfonic acid groups to various shapes of polyethylene, polypropylene and polytetrafluoroethylene by radiation-induced graft polymerization. React. Polym. v. 21, p.187-191, 1993.

36 TSUNEDA, S.; SAITO K.; FURUSAKI, S.; SUGO, T.; MAKUUCHI, K. Simple Introduction of Sulfonic Acid Group onto Polyethylene by Radiation-Induced Cografting of Sodium Styrenesulfonate with Hydrophilic Monomers. Ind. Eng. Chem. Res. v. 32, p. 1464-1470, 1993.

37 LI, L.; DENG, B.; JI, Y.; YU, Y.; XIE, L.; LI , J.; LU, X. A novel approach to prepare proton exchange membranes from fluoropolymer powder by preirradiation induced graft polymerization. J. Membrane Sci. v. 346, p.113-120, 2010.

38 KIM, Y.W.; LEE, D.K.; LEE, K.J.; KIM, J.H. Single-step synthesis of proton conducting poly(vinylidene fluoride) (PVDF) graft copolymer electrolytes. Eur. Polym. J. v. 44, p. 932-939, 2008.

39 MANO, E.B.; MENDES, L.C. Introdução a polímeros. 2. ed. São Paulo: Edgard Blücher, 2001.

40 ODIAN, G. Principles of polymerization. 4. ed. New York, NY: John Wiley \& Sons, 2004. 
41 HARPER, C.A. (Ed.). Modern Plastics Handbook. New York, NY: McGrawHill, 2000.

42 DROBNY, J.G. Technology of Fluoropolymers, 2. Ed. Boca Raton, FL: CRC, 2009.

43 WIEBECK, H.; HARADA, J. Plásticos de engenharia - tecnologia e aplicações, Artliber, 2005.

44 LOVINGER, A.J. In: BASSET, D.C. Developments in crystalline polymers, London, Applied Science, 1982, p. 196-273.

45 GREGORIO JÚNIOR, R.; CESTARI, M. Effect Of Crystallization Temperature On The Crystalline Phase Content And Morphology Of Poly(Vinylidene Fluoride). J. Polym. Sci. Pol. Phys. v. 32, p. 859-870, 1994.

46 SONG, D.; YANG, D.; FENG, F. Formation of beta-phase microcrystals from the melt of PVF2-PMMA blends induced by quenching. J. Mater. Sci. v. 25, p. 5764, 1990.

47 ELLIS, B.; SMITH, R. (Ed.), Polymers, a property database, 2. ed. Boca Raton, FL: CRC, 2009.

48 LI-YING TIAN, XIAO-BIN HUANG, XIAO-ZHEN TANG. Study on Morphology Behavior of PVDF-Based Electrolytes. J. Appl. Polym. Sci. v. 92, p. 38393842, 2004.

49 NAEGELE, D.; YOON, D.Y.; BROADHURST, M.G. Formation of a New Crystal Form (ap) of Poly(vinylidene fluoride) under Electric Field. Macromolecules v. 11, 6 ed., p. 1297-1298, 1978.

50 SCHEINBEIN, J.I. Poly(vinylidene fluoride). In: MARK, J. E. (Ed.) Polymer data handbook, Oxford, New York,NY: 1999, p. 949-955.

51 GREGORIO JÚNIOR, R. Determination of the $\alpha, \beta$ and $y$ crystalline phases of poly(vinylidene fluoride) films prepared at different conditions. J. Appl. Polym. Sci. v. 100, p. 3272-3279, 2006.

52 SPINKS, J.W.T.; WOODS, R.J. An intoduction to radiation chemistry. 3. ed. New York, NY: John Wiley \& Sons, 1990. 
53 HAJI-SAEID, M.; SAMPA, M.H.; RAMAMOORTHY, N.; GUVEN, O.;

CHMIELEWSKI, A.G. The role of IAEA in coordinating research and transferring technology. Nucl. Instrum. Meth. B. v. 265 p. 51-57, 2007.

54 BRADLEY, R. Radiation Technology Handbook, Marcel Dekker, New York, NY, 1984.

55 DAWES, K.; GLOVER, L.C.; VROOM, D.A. The effects of electron beam and yirradiation on polymeric materials. In: MARK, J. E. (ed.) Physical properties of polymers handbook, 2 ed. Springer, 2007.

56 CHAPIRO, A., FOËX, M., JENDRYCHOWSKA-BONAMOUR, A. M. Greffage radiochimique de l'acetate de vinyle et du styrene sur la nitrocellulose - I partie cinetique. Eur. Polym. J. v.13, p. 637-642, 1977.

57 CHAPIRO, A., FOËX, M., JENDRYCHOWSKA-BONAMOUR, A. M. Greffage radiochimique de l'acetate de vinyle et du styrene sur la nitrocellulose - I separation et caracterisation des copolymeres greffes. Eur. Polym. J. v.13, p. 643-649, 1977.

58 GERALDES, A.N.; ZEN, H.A.; RIBEIRO, G.; FERREIRA, H.P.; SOUZA, C.P.; PARRA, D.F.; SANTIAGO, E.I.; LUGÃO, A.B. Post-irradiation time effects on the graft of poly (ethylene-alt-tetrafluoroethylene) (ETFE) films for ion exchange membrane application. Radiat. Phys. Chem. v. 79, p. 246-249, 2010.

59 WALSBY, N.; PARONEN, M.; JUHANOJA, J.; SUNDHOLM, F. Radiation grafting of styrene onto poli(vinylidene fluoride) films in propanol: the influence of solvent and synthesis conditions, J. Poly. Sci. A1, v. 38, p. 1512-1519, 2000.

60 GUBLER, L.; PROST, N.; GURSEL, S.A.; SCHERER, G.G. Proton exchange membranes prepared by radiation grafting of styrene/divinylbenzene onto poly(ethylene-alt-tetrafluoroethylene) for low temperature fuel cells. Solid State Ionics. v. 176, p. $2849-2860,2005$.

61 HORSFALL, J.A.; LOVELL, K.V. Synthesis and characterization of sulfonic acid-containing ion exchange membranes based on hydrocarbon and fluorocarbon polymers. Eur. Polym. J. v. 38, p. 1671-1682, 2002. 
62 FLINT, S.D.; SLADE, R.C.T. Investigation of radiation-grafted PVDF-gpolystyrene-sulfonic-acid ion exchange membranes for use in hydrogen oxygen fuel cells. Solid State Ionics. v. 97, p. 299-307, 1997.

63 YEW, Y.K.; NG, T.Y.; Li, H.; LAM, K.Y. Analysis of pH and electrically controlled swelling of hydrogel-based micro-sensors/actuators. Biomed. Microdevices, v. 9, p. 487-499, 2007.

64 CALDWELL, D.G.; TAYLOR, P.M. Chemically stimulated pseudo-muscular actuation. Int. J. Eng. Sci. v. 28, n. 8, p. 797-808, 1990.

65 HIRAI, T. Electrically Active Non-ionic Artificial Muscle. J. Intel Mat. Syst. Str. v. 18, p. 117-122, 2007.

66 MADDEN, J.D.W.; VANDESTEEG, N.A.; ANQUETIL, P.A.; MADDEN, P.G.A.; TAKSHI, A.; PYTEL, R.Z.; LAFONTAINE, S.R.; WIERINGA, P.A.; HUNTER, I.W. Artificial Muscle Technology: Physical Principles and Naval Prospects, IEEE J. Oceanic Eng. v. 29, n. 3, 2004.

67 CHEN, Q., XIONG, K., BIAN, K., JIN, N., WANG, B. Preparation and performance of soft actuator based on IPMC with silver electrodes. Front. Mech. Eng. China, v. 4, n. 4, p. 436-440, 2009.

68 CHUNG, C.K., FUNG, P.K., HONG, Y.Z., JU, M.S., LIN, C.C.K., WU, T.C. A novel fabrication of ionic polymer-metal composites (IPMC) actuator with silver nano-powders. Sensors Actuat. B-Chem. v. 117, p. 367-375, 2006.

69 Punning, A., Kruusmaa, M., Aabloo, A., Surface resistance experiments with IPMC sensors and actuators. Sensors Actuat. A-Phys. v. 133, p. 200-209, 2007.

70 LEE, H.K.; CHOI, N.J.; JUNG, S.; PARK, K.H.; JUNG, H.; SHIM, J.K.; RYU, J. W.; KIM. J. Electroactive polymer actuator for lens-drive unit in auto-focus compact camera module, ETRI J. v. 31, n. 6, p. 695- 702, 2009.

71 KIM, K.J.; SHAHINPOOR, M. Ionic polymer-metal composites: II. Manufacturing techniques, Smart Mater. Struct. v. 12, p. 65-79, 2003.

72 SHAHINPOOR, M.; KIM, K.J. Ionic polymer-metal composites: III. Modeling and simulation as biomimetic sensors, actuators, transducers, and artificial muscles, Smart Mater. Struct. v. 13, p. 1362-1388, 2004. 
73 KIM, K.J.; SHAHINPOOR, M. A novel method of manufacturing threedimensional ionic polymer-metal composites (IPMCs) biomimetic sensors, actuators and artificial muscles, Polymer, v. 43, p. 797-802, 2002.

74 SHAHINPOOR, M.; KIM, K.J. Novel ionic polymer-metal composites equipped with physically loaded particulate electrodes as biomimetic sensors, actuators and artificial muscles, Sensor Actuat. A-Phys. v. 96, p. 125-132, 2002.

75 SHAHINPOOR, M.; Ionic polymer - conductor composites as biomimetic sensors, robotic actuators and artificial muscles - a review, Electrochimi. Acta, v. 48, p. $2343-2353,2003$.

76 HAN, M.J.; PARK, J.H.; LEE, J.Y.; JHO, J.Y. Ionic Polymer-Metal Composite Actuators Employing Radiation-Grafted Fluoropolymers as lon-Exchange Membranes, Macromol. Rapid Comm. v. 27, p. 219-222, 2006.

77 KUCERA, F.; JANCAR, J. Homogeneous and heterogeneous sulfonation of polymers: a review. Polym. Eng. Sci. v. 38, n. 5, p. 783-792, 1998.

78 SHAHINPOOR, M.; KIM, K.J. The effect of surface-electrode resistance on the performance of ionic polymer-metal composite (IPMC) artificial muscles, Smart Mater. Struct. n. 9, p. 543-551, 2000.

79 OGURO, K. Preparation Procedure lon-Exchange Polymer Metal Composites (IPMC) Membranes. Disponível em: <http://ndeaa.jpl.nasa.gov/nasande/lommas/eap/IPMC_PrepProcedure $>$. Acesso em: 10/jan/2010.

80 ASTM Standard D 570: Test method of test for water absorption of plastics. ASTM International, West Conshohocken, PA, 1998 (2010 e1). DOI: 10.1520/D0570-98R10E01.

81 MACHADO, L.D.B.; MATOS, J. do R. Análise térmica diferencial e calorimetria exploratória diferencial. In: CANEVAROLO JÚNIOR, S.V [Ed.] Técnicas de caracterização de polimeros, p. 229, Artliber, 2004.

82 MOKRINI, A.; HUNEALT, M.A. Proton exchange membranes based on PVDF/SEBS blends. J. Power Sources, v. 154, p. 51-58, 2006. 
83 LI, J.; SATO, K.; ICHIDURI, S.; ASANO, S.; IKEDA, S.; IIDA, M.; OSHIMA, A.; TABATA, Y.; WASHIO, M. Pre-irradiation induced grafting of styrene into crosslinked and non-crosslinked polytetrafluoroethylene films for polymer electrolyte fuel cell aplication. I: influence of styrene grafting conditions, Eur. Polym. J. v. 40, p. 775-783, 2004.

84 DEDAVID, B.A.; GOMES, C.I.; MACHADO, G. Microscopia eletrônica de varredura - Aplicações e preparação de amostras, Materiais poliméricos, metálicos e semicondutores, EDIPUCRS, Porto Alegre, 2007.

85 GERALDES, A.N., ZEN, H.A., PARRA, D.F., FERREIRA, H.P., LUGÃO, A.B. Effects of solvents on post-irradiation grafting of styrene onto fluoropolymer films. E-Polymers. n. 63, p. 1-12, 2008.

86 DUSAUCY, A.C.; TILQUIN, B. Selectivity in dehydrodimerisation of amides: final product analysis from radiolysis in the liquid phase, Radiat. Phys. Chem. v. 37, n. 2, p. 217-220, 1991.

87 ICHINOSE, N.; HOBO, J.; TOJO, S.; MAJIMA, T. Observation of intramolecular dimer radical anion of 1,1-diarylmethanols bearing electron withdrawing groups at room temperature. Chem. Phys. Lett. v. 330, p. 97-102. 2000.

88 HAYASHI, N.; HAYON, E.; IBATA, T.; LICHTIN, N.N.; MATSUMOTO, A. Pulse Radiolysis of Liquid Amides, J. Phys. Chem.-US, v. 76, n. 16, 1972.

89 XIAO-HUI LIU; YAN-GUO LI; YING LIN; YUE-SHENG LI. 2-Cyanoprop-2-yl Dithiobenzoate Mediated Reversible Addition-Fragmentation Chain Transfer Polymerization of Acrylonitrile Targeting a Polymer with a Higher Molecular Weight. J. Polym. Sci. A1, v. 45, p. 1272-1281, 2007.

90 MOGHADAM, S.S.; BAHRAMI, S.H. Copolymerization of Acrylonitrile-acrylic Acid in DMF-water Mixture. Iran. Polym. J. v. 14, n. 12, p. 1032-1041, 2005.

91 SUGIHARA, Y.; O'CONNOR, P.; ZETTERLUND, P.B.; ALDABBAGH, F. Chain Transfer to Solvent in the Radical Polymerization of N-Isopropylacrylamide. J. Polym. Sci. A1, v. 49, p. 1856-1864, 2011.

92 VANDERMEER, R.; AARTS, M.W.A.M.; GERMAN, A.L. Effect of Solvent on the Copolymerization of Ethylene and Vinyl Acetate. J. Polym. Sci. A1, v. 18, p. 1347-1357, 1980. 
93 TOOHEY, A.C.; WEALE, K.E. Chain transfer to solvent in styrene polymerization. Part 1.- Solvent transfer constants for polymerization with an initiator. Trans. Faraday Soc. v. 58, p. 2439-2445, 1962.

94 TOOHEY, A.C.; WEALE, K.E. Chain transfer to solvent in styrene polymerization. Part 2.- The effect of pressure on the solvent transfer reaction. Trans. Faraday Soc. v. 58, p. 2446-2451, 1962.

95 GAFUROV, A.K.; YAKUBOV, N.I. A study of mechanical heat stability and resistance to thermal degradation in copolymers of vinyl fluoride with fluoroethilenes., Polymer Science U.S.S.R. v. 29, n. 8, p. 1895-1901, 1987.

96 VIEN, L.D.; COLTHUP, N.B.; FATELEY, W.G.; GRASSELLI, J.G. The handbook of infrared and Raman characteristics frequencies of organic molecules. Academic, 1991. 